KEY WORDS: Tank Sampling

Tank 19F

Tank Closure

\title{
Statistical Analysis of Tank 19F Floor Sample Results
}

\author{
S. P. Harris
}

SEPTEMBER 2, 2010

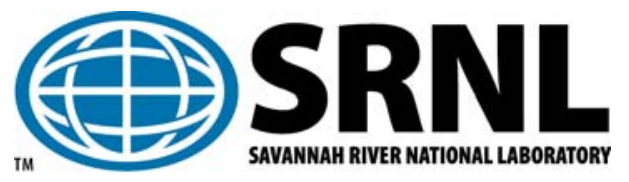

Savannah River National Laboratory

Savannah River Nuclear Solutions

Savannah River Site

Aiken, SC 29808

This document was prepared in conjunction with work accomplished under Contract No. DE-AC09-08SR22470 with the U.S. Department of Energy 


\section{DISCLAIMER}

This work was prepared under an agreement with and funded by the U.S Government. Neither the U. S. Government or its employees, nor any of its contractors, subcontractors or their employees, makes any express or implied: 1 . warranty or assumes any legal liability for the accuracy, completeness, or for the use or results of such use of any information, product, or process disclosed; or 2. representation that such use or results of such use would not infringe privately owned rights; or 3. endorsement or recommendation of any specifically identified commercial product, process, or service. Any views and opinions of authors expressed in this work do not necessarily state or reflect those of the United States Government, or its contractors, or subcontractors. 
Author:

S. P. Harris, Author

Applied Computational Engineering and Statistics

Review/Approval:

E. P. Shine, Technical Reviewer

Applied Computational Engineering and Statistics

F. M. Pennebaker, Manager

Advanced Characterization \& Processing

W. B. Dean, Closure and Disposal Assessment

Savannah River Remediation

G. D. Thaxton, Closure Project Engineering

Savannah River Remediation

P. L. Lee, Manager

Applied Computational Engineering and Statistics
Date

Date

Date

Date

Date

Date 
Statistical Analysis of Tank 19F Floor Sample Results

This page intentionally left blank 


\section{TABLE OF CONTENTS}

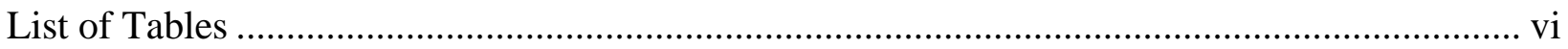

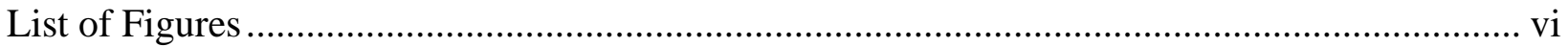

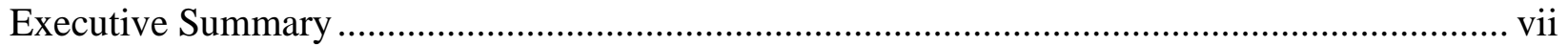

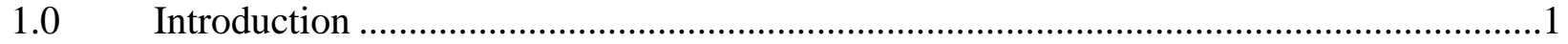

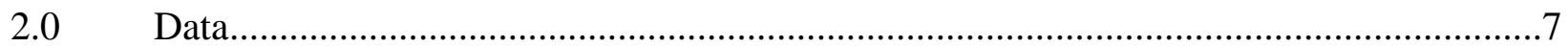

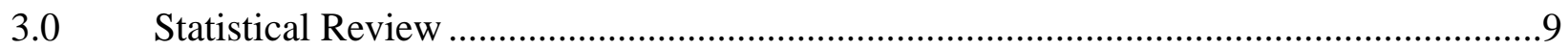

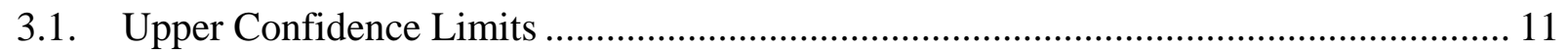

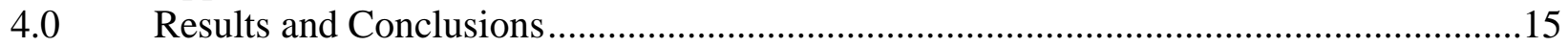

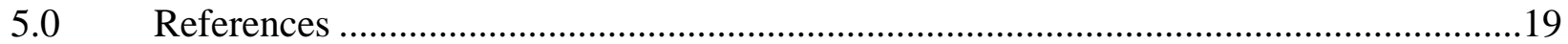

Appendix 1. Sequence Plots for Tank 19F Mantis and Scrape Sample Results.......................21

Appendix 2. 3-Sigma Plots for Tank 19F Mantis and Scrape Sample Results Normalized ......27

Appendix 3a. 3-Sigma Plots for Tank 19F Current Scrape Sample Results Normalized ........29

Appendix 3b 3-Sigma Plots for Tank 19F Current Scrape Sample Results Normalized

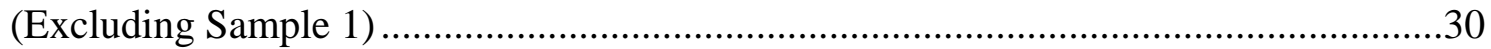

Appendix 4. Plot of Tank 19F Prior Scrape (QA Sample) Results versus Current Scrape

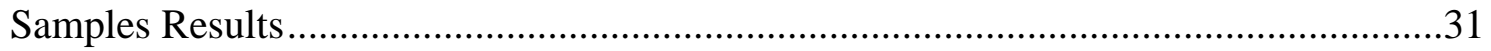

Appendix 5. Tank 19F Summary Statistics and Upper 95\% Confidence Limits by Analyte ....33 


\section{LIST OF TABLES}

Table 1. Tank 19F Floor Samples (February 2010)

Table 2. Statistical Models and Data Sources for Testing Mantis vs Scrape, North vs. South Hemisphere and Inner vs. Outer Region Differences.

Table 3. Constituent Averages, Standard Deviations, and UCL $95 \%$ for the Current Scrape Samples on a Dried Solids Basis

Table 4. Current Scrape Sample Constituents with 2 or 3 Repeat

Table 5. Tail Probabilities (p values) and Significance Testing for Regional Differences (Inner vs. Outer, North vs. South Hemispheres) using the Current Scrape Samples.

Table 6. Tail Probabilities (p values) and Significance Testing for Mantis, Scrape Sample and Hemisphere Differences

\section{LIST OF FIGURES}

Figure 1. Previous Mantis rover sampling locations in Tank 19........................................3

Figure 2. Tank 19 Scrape Sample Locations (Southern Hemisphere) .....................................4

Figure 3. Tank 19 Current Scrape Samples........................................................................5 


\section{EXECUTIVE SUMMARY}

Representative sampling has been completed for characterization of the residual material on the floor of Tank 19F as per the statistical sampling plan developed by Harris and Shine [1]. Samples from eight locations have been obtained from the tank floor and two of the samples were archived as a contingency. Six samples, referred to in this report as the current scrape samples, have been submitted to and analyzed by SRNL [2].

This report contains the statistical analysis of the floor sample analytical results to determine if further data are needed to reduce uncertainty. Included are comparisons with the prior Mantis samples results [3] to determine if they can be pooled with the current scrape samples to estimate the upper 95\% confidence limits (UCL95\%) for concentration.

Statistical analysis revealed that the Mantis and current scrape sample results are not compatible. Therefore, the Mantis sample results were not used to support the quantification of analytes in the residual material. Significant spatial variability among the current scrape sample results was not found. Constituent concentrations were similar between the North and South hemispheres as well as between the inner and outer regions of the tank floor. The current scrape sample results from all six samples fall within their 3-sigma limits. In view of the results from numerous statistical tests, the data were pooled from all six current scrape samples. As such, an adequate sample size was provided for quantification of the residual material on the floor of Tank 19F.

The uncertainty is quantified in this report by an upper 95\% confidence limit (UCL95\%) on each analyte concentration. The uncertainty in analyte concentration was calculated as a function of the number of samples, the average, and the standard deviation of the analytical results. The $U C L_{95 \%}$ was based entirely on the six current scrape sample results (each averaged across three analytical determinations). 
Statistical Analysis of Tank 19F Floor Sample Results

This page intentionally left blank 


\subsection{INTRODUCTION}

Representative sampling is required for characterization of the residual material on the floor of Tank 19F. Tank 19F is a Type IV underground waste storage tank located in the F-Tank Farm. It is a cylindrical-shaped, carbon steel tank with a diameter of 85 feet, a height of 34.25 feet, and a working capacity of 1.3 million gallons. Tank 19F was placed in service in 1961 and initially received a small amount of low heat waste from Tank 17. It then served as an evaporator concentrate (saltcake) receiver from February 1962 to September 1976. Tank 19F also received the spent zeolite ion exchange media from a cesium removal column that once operated in the Northeast riser of the tank to remove cesium from the evaporator overheads.

Recent mechanical cleaning of the tank removed all mounds of material resulting in a residual layer requiring characterization to support closure activities. Anticipating a low level of solids in the residual waste, Huff and Thaxton [4] developed a baseline sampling plan to sample the waste during the final clean-up process while it would still be resident in sufficient quantities to support analytical determinations in four quadrants of the tank. Execution of the baseline sampling plan produced fewer solids than expected to support analytical determinations in all quadrants. Huff and Thaxton [4] then restructured the plan to characterize the residual separately in the North and the South hemispheres.

The Huff and Thaxton [4] sampling plan focused on obtaining in-process samples using the Mantis rover. During the mechanical cleaning process, waste from Tank 19F was mobilized and transferred by eduction to a Waste Mix Chamber (WMC) in Tank 7. There the waste was ground by an immersion mill grinder to less than 38 microns. Once sufficiently triturated, the particles floated upward and into a sampler in the WMC.

The original sampling plan called for two in-process vials (samples) of about $125 \mathrm{ml}$ each from each of four tank quadrants: Northwest, Northeast, Southwest, and Southeast. In addition, a third $125 \mathrm{ml}$ vial per quadrant was planned as an archival sample.

The baseline plan was executed (Figure 1), and the samples were sent to the Savannah River National Laboratory (SRNL). The samples did not yield an adequate quantity of solids to support all of the analytical tests in all four quadrants. As a result, Huff and Thaxton [4] report that the sampling plan was revised by partitioning the tank into a North and a South hemisphere. In addition to the Mantis rover samples, a quality assurance (QA) scrape sample was obtained near the center riser slightly within the Southern hemisphere by scraping material from the tank floor (Figure 2). The amount of solids in the scrape sample was sufficient to support the analysis of a subset of key analytes.

The sampling plan was revised several more times for various reasons. First, the justification for using in-process samples for characterization was based upon an assumption that the mechanical cleaning of the tanks would result in a tank that was so clean that it would not be possible to retrieve a sufficient quantity of sample solids to perform a full characterization of the residual waste. This assumption was proven false at the completion of mechanical cleaning. Additional revisions resulted from a statistical review of the preliminary sample analysis results (which indicated that additional data was needed) and due to the addition of more analytes in the sample 


\section{Statistical Analysis of Tank 19F Floor Sample Results}

analyses (which required a larger mass of sample material at each sample location).

A subsequent sampling plan developed by Harris and Shine [1] was implemented to complete the characterization of the residual material on the floor of the tank. Specifically, the sample size was determined from a modification of the formula previously published in Edwards [4] and the sample characterization data for previous sampling of Tank 19F described by Oji [3]. The Harris and Shine sampling plan [1] was based on partitioning the Tank 19F floor into an inner and an outer ring and six $60^{\circ}$ sectors as depicted in Figure 3. The inner and outer regions were selected so that each region contains approximately fifty percent of the residual material. The location of the border between the inner and outer rings is based on dividing the residual material into two approximately equal volumes. Apart from the new samples to be archived, there were three samples taken from each hemisphere. In order to balance the samples between the inner and outer rings, two of the additional samples were taken from the outer ring in each hemisphere. The two samples, one from each hemisphere, slated to be archived were taken from the inner ring, since they are the primary contingency if the Mantis samples were demonstrated to be incompatible with the scrape samples. The scrape samples that were archived were closest to the Mantis sample in each hemisphere.

A scrape sample taken from the floor was obtained from each of the six sectors, three in each hemisphere (North and South), consisting of one within the inner and two within the outer region of each hemisphere. In addition, two samples were taken within the inner region (one in each hemisphere) and archived.

This sampling plan assumed that concentration may differ between the North and South hemispheres so each hemisphere was sampled independently. The sampling plan supported separate quantification of the analyte concentrations in the two hemispheres if the results from the North and the South hemispheres were not demonstrated to be similar. 


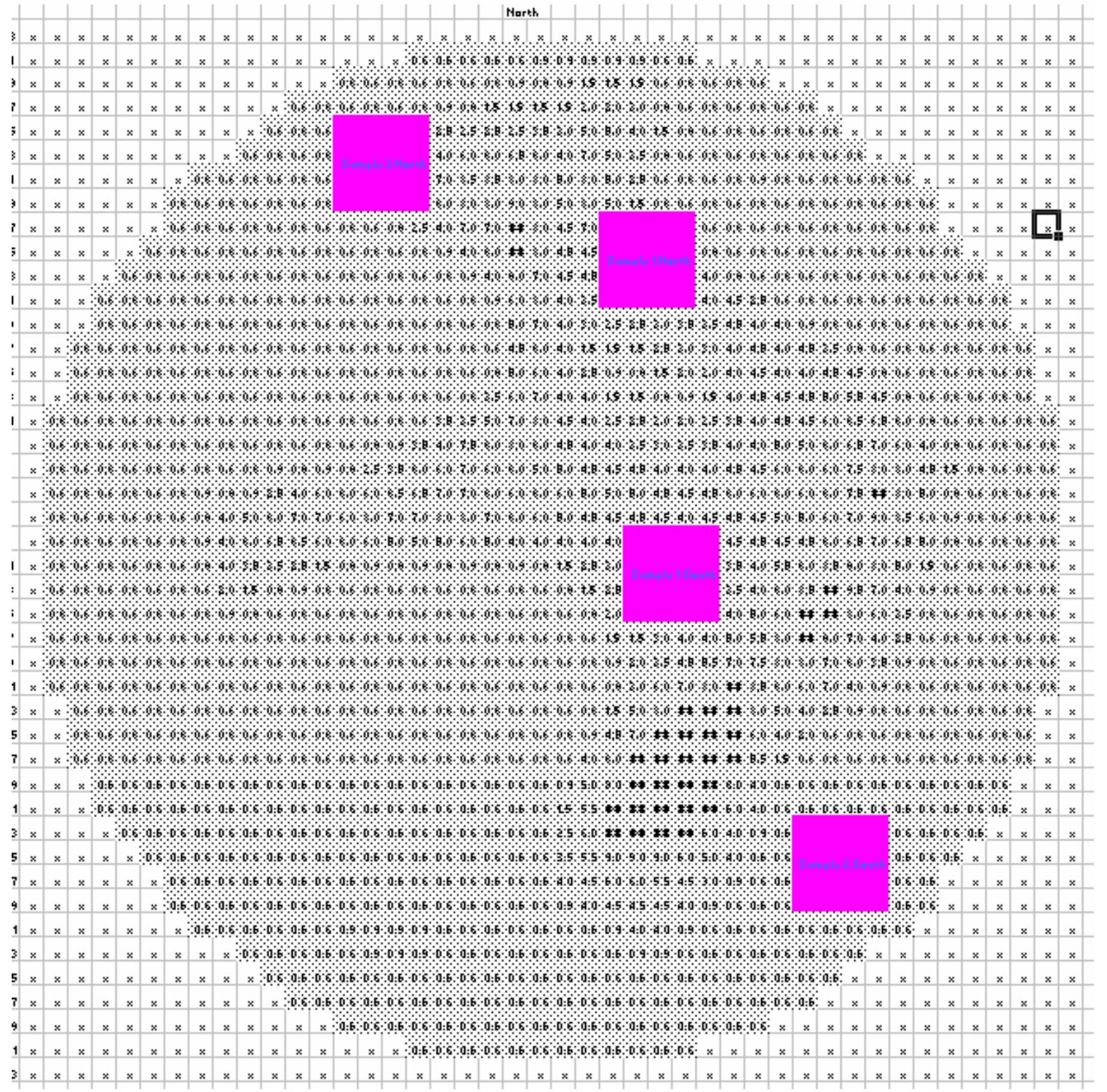

Figure 1. $\quad$ Previous $^{1}$ Mantis rover sampling locations in Tank $19^{2}$

${ }^{1}$ Each of squares forming the grid is 2-by-2 feet square.

2 Table information from E-mail communication from K. Barbour, Type IV Tank Closure org., August 10, 2009 
Statistical Analysis of Tank 19F Floor Sample Results

Figure 2. Tank 19 Scrape Sample Locations (Southern Hemisphere)

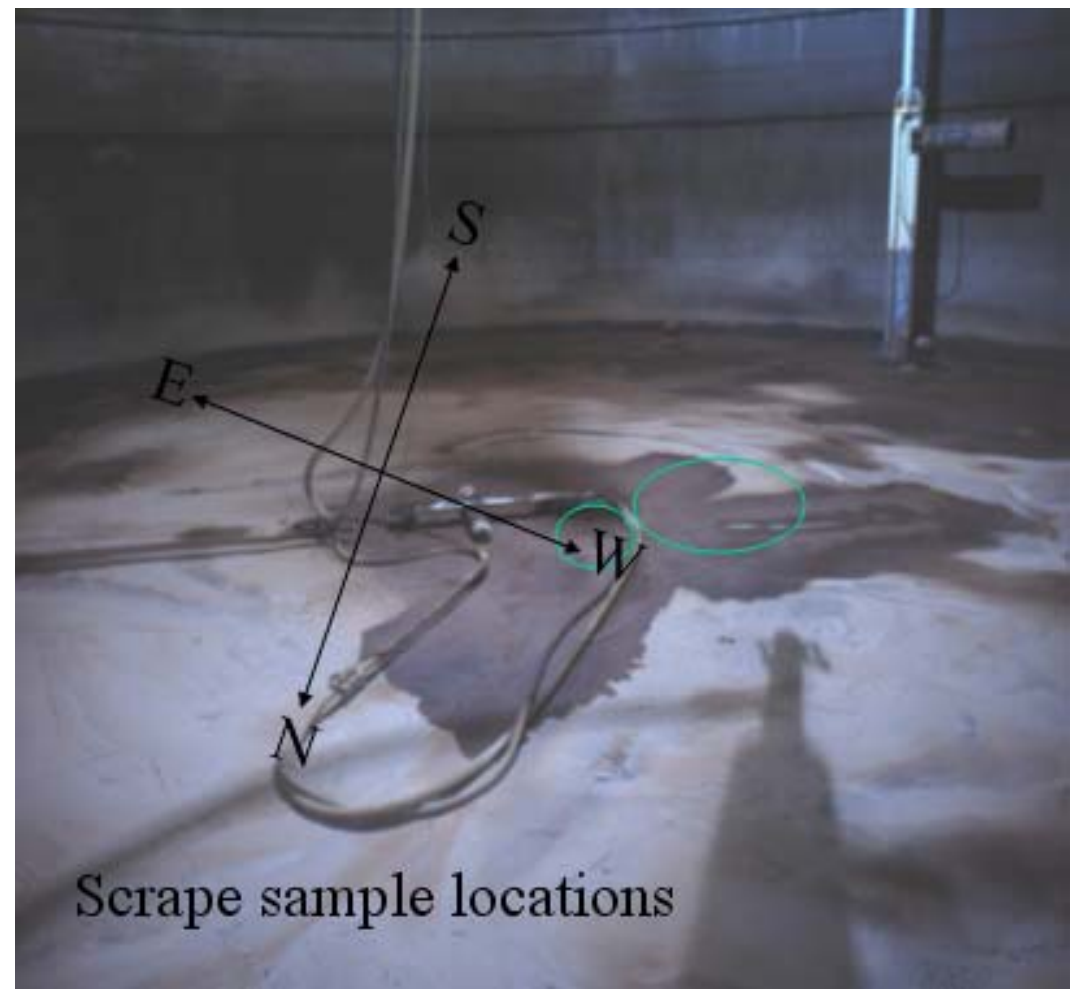




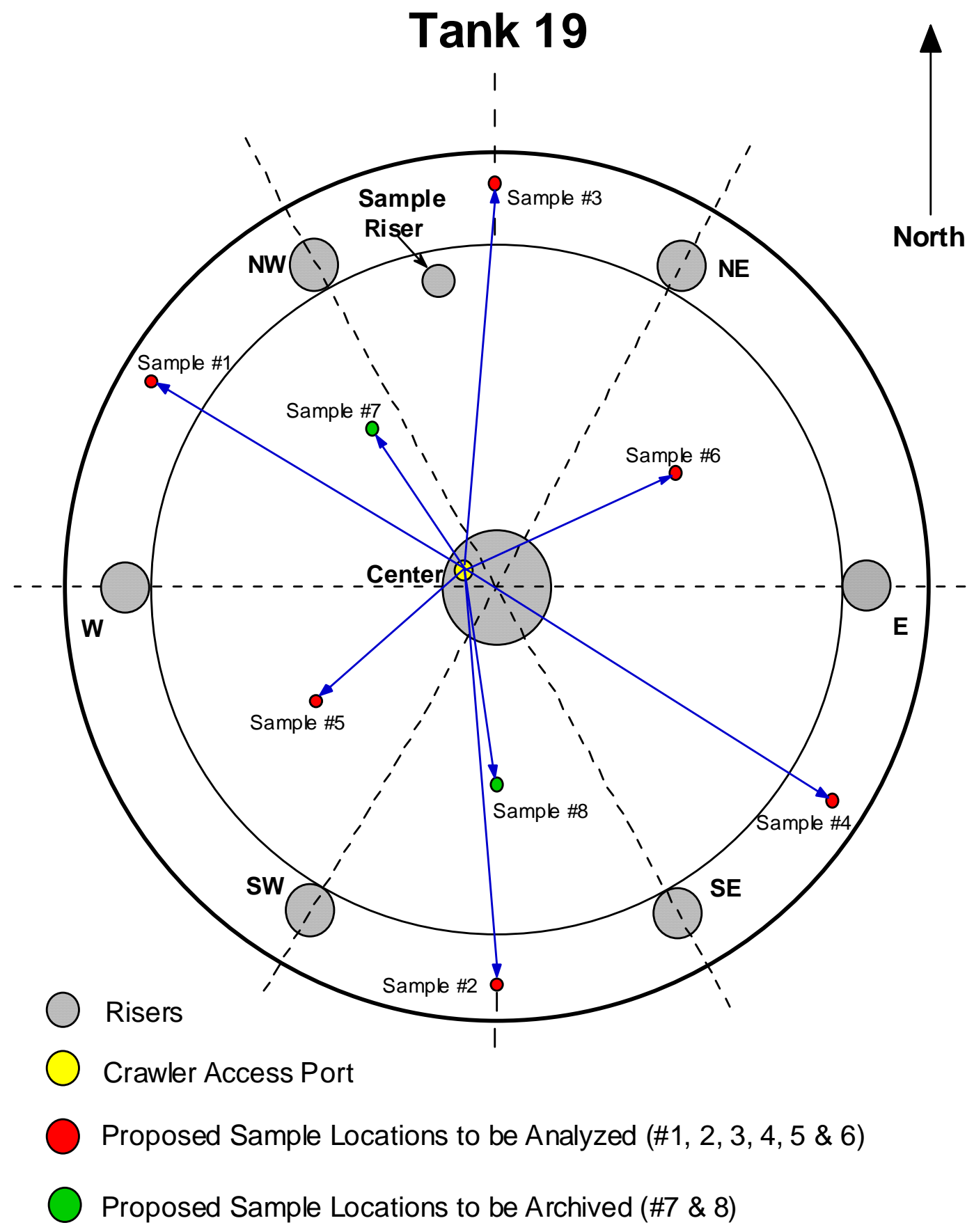

Samples are numbered based on retrieval priority order

Figure 3. Tank 19 Current Scrape Samples 
Statistical Analysis of Tank 19F Floor Sample Results

This page intentionally left blank 


\subsection{DATA}

The current floor scrape samples [FTF-19-1, FTF-19-2, FTF-19-3, FTF-19-4, FTF-19-5, FTF19-6, FTF-19-7 and FTF-19-8 in Table 1] were taken from Tank 19F floor in February, 2010 and made available to SRNL for analyses in the same month. Sample FTF-19-7 and FTF-19-8 served as archived samples and thus were not analyzed. The suffix on each Sample ID is referred to as the sample number. The corresponding sectors (non-overlapping $60^{\circ}$ segment of the tank) where the samples were taken are listed in Table 1. The six Tank 19F samples ("as-received") were digested at SRNL and characterized without further processing such as drying. The conversion to a dried solids basis (original "as received" basis to dry basis) was accomplished through the use of the weight percent solid (wt \%) [2, 3]. For example, $\mu \mathrm{Ci} / \mathrm{g}$ dry solids $=[\mu \mathrm{Ci} / \mathrm{g}$ of "as received solids" x (100/ wt \% solids)].

Table 1. Tank 19F Floor Samples (February 2010)

\begin{tabular}{|r|r|l|r|r|c|c|c|}
\hline $\begin{array}{c}\text { Sample } \\
\text { ID }\end{array}$ & Sector & Hemisphere & Min & Max & Sample ID & $\begin{array}{c}\text { Inner/ } \\
\text { Outer } \\
\text { Code }\end{array}$ & Analyzed/ \\
\hline 1 & 3 & North & 120 & 180 & FTF-19-1 & Outer & Analyzed \\
\hline 2 & 5 & South & 240 & 300 & FTF-19-2 & Outer & Analyzed \\
\hline 3 & 2 & North & 60 & 120 & FTF-19-3 & Outer & Analyzed \\
\hline 4 & 6 & South & 300 & 360 & FTF-19-4 & Outer & Analyzed \\
\hline 5 & 4 & South & 180 & 240 & FTF-19-5 & Inner & Analyzed \\
\hline 6 & 1 & North & 0 & 60 & FTF-19-6 & Inner & Analyzed \\
\hline 7 & 3 & North & 120 & 180 & FTF-19-7 & Inner & Archived \\
\hline 8 & 5 & South & 240 & 300 & FTF-19-8 & Inner & Archived \\
\hline
\end{tabular}

Three replicate measurements were made for each analyte and sample. Analysis results reported by SRNL [2, 3] with values preceded by “<” (less than sign) indicate that the values were below detection limits (Table 4). Sample results with two or three repeat analyses below detection were not included in the statistical estimation. The censored data estimation procedure in Statgraphics [6] was used to estimate the mean when one value out of three was below the detection limit. 
Statistical Analysis of Tank 19F Floor Sample Results

This page intentionally left blank 


\subsection{STATISTICAL REVIEW}

The current floor scrape sample results were compared to the results from the Mantis samples to determine if the Mantis and current scrape sample results can be pooled to estimate the upper 95\% confidence limits (UCL95\%) for concentration. Statistical analysis of the analytical results revealed that the Mantis and current scrape sample results are not compatible. The Mantis samples, retrieved after grinding from the Waste Mix Chamber, may have been altered based on the residence time in the grinder. Therefore, the Mantis results were not used to quantify the analytes in the residual material. The results from the prior quality assurance scrape sample were not included in calculating $U C L_{95 \%}$ because they were only available for approximately $25 \%$ of measured analytes. The QA scrape sample results all fall within the 3-sigma limits. Their inclusion with the current scrape sample results would have a negligible impact (within 3\%) on the upper $95 \%$ confidence limits for most analytes.

After a statistical comparison demonstrated spatial similarity, the results from the entire tank were consolidated into a single unit. As a result, adequate sample size was obtained for quantification of the residual material on the floor of Tank 19F. Analyzing the archive samples was not necessary since essentially no significant difference was found between the North and South hemispheres measurements (except for Hg). Furthermore, no significant differences were found between the inner and outer regions (except for Fe). The uncertainty was quantified by an upper $95 \%$ confidence limit (UCL $L_{95 \%}$ ) on each analyte concentration. The uncertainty in analyte concentration was calculated as a function of the number of samples, the average, and the standard deviation of the analytical measurements. The $U C L_{95 \%}$ was based entirely on the six current scrape sample results each averaged across three determinations.

The statistical tests that were conducted and the data used for evaluating the differences between hemispheres and also between the inner and outer regions are listed in Table 2. No significant differences were found between the inner and outer regions within hemispheres (except for Fe in the North Hemisphere) and in addition no significant differences were found between the hemispheres except for $\mathrm{Hg}$ (Table 5). Finally an overall test revealed that only the $\mathrm{Fe}$ concentration difference between the inner and outer regions was significant. In comparing the current scrape sample results with the Mantis sample results, significant differences were found within hemispheres for Am-241, Cd, Co-60, Cs-135, Eu-154, Hg, Np-237, Pu238, Sm-151, Ti, U234 and U238 (Table 6 with entries 0.05 or less). 
Table 2. Statistical Models and Data Sources for Testing Mantis vs Scrape, North vs. South Hemisphere and Inner vs. Outer Region Differences

\begin{tabular}{|l|l|c|c|l|l|}
\hline $\begin{array}{c}\text { Data Used (Y) } \\
\text { (Dry Solids) }\end{array}$ & Terms in Model & Nested Terms & $\begin{array}{c}\text { Results } \\
\text { Table }\end{array}$ & $\begin{array}{c}\text { Columns } \\
\text { in Table }\end{array}$ & \multicolumn{1}{|c|}{ Tests } \\
\hline New Scrape Only & Hemisphere & Inner_Outer[Hemisphere] & Table 5 & Cols 2, 3 & $\begin{array}{l}\text { Inner vs. Outer within } \\
\text { Hemisphere }\end{array}$ \\
\hline New Scrape Only & Hemisphere & n/a & Table 5 & Col 4 & North vs. South Overall \\
\hline New Scrape Only & Hemisphere & Inner_Outer[Hemisphere] & Table 5 & Col 5 & $\begin{array}{l}\text { Overall Inner vs. Outer and } \\
\text { North vs. South }\end{array}$ \\
\hline New Scrape and Mantis & Hemisphere & Scrape_Mantis[Hemisphere] & Table 6 & Cols 2, 3 & $\begin{array}{l}\text { New Scrape vs Mantis; North } \\
\text { within Hemisphere }\end{array}$ \\
\hline New Scrape and Mantis & Hemisphere & n/a & Table 6 Col 4 & North vs. South Overall \\
\hline New Scrape and Mantis & Hemisphere & Scrape_Mantis[Hemisphere] & Table 6 & Col 5 & $\begin{array}{l}\text { Overall New Scrape vs } \\
\text { Mantis and North vs. South }\end{array}$ \\
\hline
\end{tabular}

Sequence plots by sector (Sector definitions are in Table 1) are displayed in Appendix 1 for the current scrape sample results for the analytes above detection. The results for the inner region are displayed using solid black dots while the results for the outer region are displayed using open dots. In addition, the Mantis sample results and the prior scrape sample results are superimposed on the sequence plots. Generally, no discernable patterns were found in the sequence plots for the current scrape samples going counterclockwise around the tank from due east (Zero degrees). The differences noted while conducting significance tests were corroborated through visual inspection of the sequence plots. The Mantis sample results do not overlap the current scrape samples for a number of analytes. In particular, both the North and South Mantis sample results are both either higher or lower than the six current scrape sample results for Cs135, Nitrate, Np-237 and U-233.

The data (z-score) for constructing 3-sigma charts were standardized by subtracting the average and then dividing by the sample standard deviation calculated from the current floor scrape data. If the data are well behaved and fall into the same range as the current scrape samples, the plotted points should fall between plus and minus three. The 3-sigma charts for the standardized data are displayed in Appendix 2, 3a and 3b. Review of the chart in Appendix 2 suggests that the new scrape sample and Mantis sample results are not similar. The Mantis results and the prior scrape sample results were eliminated from the plot and the remaining results (Current Scrape Sample) are displayed in Appendix 3a. The Sample 1 (Sector 3: 120 to $180 \mathrm{deg}$ ) result is at the upper range for a number of analytes (e.g.: Am-241, Am-243, Cs-137). To compare Sample 1 with the remaining scrape samples (Samples 2 through 6), the current scrape sample results were standardized by using the average and standard deviations for samples 2 through 6 (Appendix 3b). The plot shows that Am-241, Am-243, Eu-154, Pu-238 and Tc-99 from Sample 1 are outside the upper control limit (+3). Both Ba-137m and Cs-137 are below the lower control limit (-3). The current scrape sample results from all six samples fall within the 3-sigma control limits (Appendix 3a). Therefore, the results from all six samples were used in calculating the confidence limits. 


\section{1. $\quad$ Upper Confidence Limits}

The upper 95\% confidence limits were established for analytes that have supporting data (an adequate number of results above the detection limit). The limit establishes a credible upper bound on the concentration of analyte $a$ in the residual material on the floor of the tank. The form of the interval is as follows.

$$
U C L_{95 \%}=\bar{x}_{a}+t_{0.95, d f} s_{a} / \sqrt{n},
$$

where $\bar{x}_{a}$ is the average of the sample means of analyte $a, s_{a}$ is the corresponding sample standard deviation, and $t_{0.95, d f}$ is the upper $95^{\text {th }}$ percentile of the t-distribution with $d f$ degrees of freedom. For the current scrape samples, $n$ is usually equal to six and $t_{0.95,5}=2.02$. The $d f$ is the degrees of freedom associated with $s_{a}$, based on $n-1$ sampling degrees of freedom where $n$ is the number of samples. The standard deviation includes sample preparation variation, measurement error and the sampling variation within Tank 19F.

The $U C L_{95 \%}$ depends on the sample design, the number of samples in each stratum, and the number of analytical determinations per sample. An increase in the number of samples or an increase in the number of determinations per sample will generally produce a decrease in the $U C L_{95 \%}$. In the current sampling plan, the three repeat analyses on each sample and analyte were determined to be adequate [1]. These results were averaged resulting in six sample results (one for each sector).

Table 3 lists constituents that have sufficient measurements above detection to compute an $U C L_{95 \%}$. The table is based on combining the North and South hemisphere, inner and outer measurements. The estimated concentrations are in $u \mathrm{Ci} / \mathrm{g}$ or $\mathrm{Wt} \%$ dried solids dependent on the constituent measured. The $U C L_{95 \%}$ for an analyte is the upper $95 \%$ confidence limit for the average tank concentration for the analyte. The $95 \%$ level of confidence refers to the reliability of the method, in that $95 \%$ of such upper confidence will correctly bound the actual mean concentration. 
SRNL-STI-2010-00400

Statistical Analysis of Tank 19F Floor Sample Results

Table 3. Constituent Averages, Standard Deviations, and $U C L_{95 \%}$ for the Current Scrape Samples on a Dried Solids Basis

\begin{tabular}{|c|c|c|c|c|}
\hline Analyte & Units & Average & Standard Deviation & Upper 95\% Confidence Limit \\
\hline Am-241 & $\mathrm{uCi} / \mathrm{g}$ & 2.48E-01 & $7.96 \mathrm{E}-02$ & 3.14E-01 \\
\hline Am-243 & $\mathrm{uCi} / \mathrm{g}$ & 6.03E-04 & 2.58E-04 & 8.16E-04 \\
\hline Ва & $\mathrm{Wt} \%$ & $8.70 \mathrm{E}-02$ & 1.11E-02 & $9.61 \mathrm{E}-02$ \\
\hline Ba-137m & $\mathrm{uCi} / \mathrm{g}$ & $5.77 \mathrm{E}+02$ & $6.10 \mathrm{E}+01$ & $6.27 \mathrm{E}+02$ \\
\hline C-14 & $\mathrm{uCi} / \mathrm{g}$ & 2.86E-01 & 2.49E-01 & 4.90E-01 \\
\hline Cd & $\mathrm{Wt} \%$ & 1.19E-02 & $2.62 \mathrm{E}-03$ & $1.40 \mathrm{E}-02$ \\
\hline CHLORIDE & $\mathrm{Wt} \%$ & $1.87 \mathrm{E}-02$ & $6.66 \mathrm{E}-03$ & $2.42 \mathrm{E}-02$ \\
\hline Cm-244 & uCi/g & $3.81 \mathrm{E}-02$ & $1.28 \mathrm{E}-02$ & 4.87E-02 \\
\hline Co-60 & $\mathrm{uCi} / \mathrm{g}$ & 4.65E-03 & 7.85E-04 & $5.30 \mathrm{E}-03$ \\
\hline $\mathbf{C r}$ & $\mathrm{Wt} \%$ & 3.22E-02 & 4.42E-03 & 3.58E-02 \\
\hline Cs-135 & $\mathrm{uCi} / \mathrm{g}$ & $2.78 \mathrm{E}-03$ & $2.24 \mathrm{E}-04$ & 2.97E-03 \\
\hline Cs-137 & $\mathrm{uCi} / \mathrm{g}$ & $6.09 \mathrm{E}+02$ & $6.45 \mathrm{E}+01$ & $6.63 \mathrm{E}+02$ \\
\hline Eu-154 & $\mathrm{uCi} / \mathrm{g}$ & 8.46E-04 & 2.19E-04 & 1.03E-03 \\
\hline Fe & $\mathrm{Wt} \%$ & $3.75 \mathrm{E}+00$ & $1.31 \mathrm{E}+00$ & $4.83 \mathrm{E}+00$ \\
\hline FLUORIDE & $\mathrm{Wt} \%$ & $1.51 \mathrm{E}-01$ & $3.56 \mathrm{E}-02$ & $1.80 \mathrm{E}-01$ \\
\hline $\mathrm{Hg}$ & $\mathrm{Wt} \%$ & $3.26 \mathrm{E}-02$ & $1.67 \mathrm{E}-02$ & 4.63E-02 \\
\hline I-129 & $\mathrm{uCi} / \mathrm{g}$ & 7.64E-06 & 4.22E-06 & $2.65 \mathrm{E}-05$ \\
\hline Mn & $\mathrm{Wt} \%$ & $1.67 \mathrm{E}-01$ & $2.46 \mathrm{E}-02$ & $1.88 \mathrm{E}-01$ \\
\hline NITRATE & $\mathrm{Wt} \%$ & $1.55 \mathrm{E}+00$ & $6.25 \mathrm{E}-01$ & $2.06 \mathrm{E}+00$ \\
\hline NITRITE & $\mathrm{Wt} \%$ & 8.07E-01 & $3.14 \mathrm{E}-01$ & $1.07 \mathrm{E}+00$ \\
\hline Np-237 & $\mathrm{uCi} / \mathrm{g}$ & $1.53 \mathrm{E}-04$ & $1.81 \mathrm{E}-05$ & $1.68 \mathrm{E}-04$ \\
\hline Pd-107 & $\mathrm{uCi} / \mathrm{g}$ & 7.59E-03 & $9.71 \mathrm{E}-03$ & $2.40 \mathrm{E}-02$ \\
\hline Pu-238 & $\mathrm{uCi} / \mathrm{g}$ & $3.79 \mathrm{E}-01$ & $5.08 \mathrm{E}-02$ & $4.21 \mathrm{E}-01$ \\
\hline Pu-239 & $\mathrm{uCi} / \mathrm{g}$ & 4.02E-01 & $8.64 \mathrm{E}-02$ & 4.74E- 01 \\
\hline Pu-240 & $\mathrm{uCi} / \mathrm{g}$ & 9.84E-02 & 2.11E-02 & $1.16 \mathrm{E}-01$ \\
\hline Pu-241 & $\mathrm{uCi} / \mathrm{g}$ & $6.50 \mathrm{E}-01$ & $1.24 \mathrm{E}-01$ & 7.53E-01 \\
\hline Ra-226 & $\mathrm{uCi} / \mathrm{g}$ & $1.15 \mathrm{E}-03$ & $3.50 \mathrm{E}-04$ & $1.44 \mathrm{E}-03$ \\
\hline Sb-126 & $\mathrm{uCi} / \mathrm{g}$ & $3.66 \mathrm{E}-04$ & $5.94 \mathrm{E}-05$ & 4.15E-04 \\
\hline Sb-126m & $\mathrm{uCi} / \mathrm{g}$ & $3.82 \mathrm{E}-04$ & $3.39 \mathrm{E}-05$ & $4.10 \mathrm{E}-04$ \\
\hline Sm-151 & $\mathrm{uCi} / \mathrm{g}$ & $1.80 \mathrm{E}-02$ & $2.50 \mathrm{E}-03$ & $2.00 \mathrm{E}-02$ \\
\hline Sn-126 & $\mathrm{uCi} / \mathrm{g}$ & 3.82E-04 & 3.39E-05 & 4.10E-04 \\
\hline Sr-90 & $\mathrm{uCi} / \mathrm{g}$ & $7.40 \mathrm{E}-01$ & $3.26 \mathrm{E}-01$ & $1.01 \mathrm{E}+00$ \\
\hline Tc-99 & $\mathrm{uCi} / \mathrm{g}$ & 3.88E-02 & 8.23E-03 & 4.55E-02 \\
\hline Th-229 & $\mathrm{uCi} / \mathrm{g}$ & $1.49 \mathrm{E}-05$ & 5.52E-06 & $2.42 \mathrm{E}-05$ \\
\hline Th-230 & $\mathrm{uCi} / \mathrm{g}$ & 7.64E-06 & $1.30 \mathrm{E}-06$ & $1.35 \mathrm{E}-05$ \\
\hline Ti & $\mathrm{Wt} \%$ & 4.97E-02 & $5.94 \mathrm{E}-03$ & $5.46 \mathrm{E}-02$ \\
\hline $\mathrm{U}-232$ & $\mathrm{uCi} / \mathrm{g}$ & $1.07 \mathrm{E}-05$ & 2.37E-06 & $1.26 \mathrm{E}-05$ \\
\hline $\mathrm{U}-233$ & $\mathrm{uCi} / \mathrm{g}$ & 4.37E-04 & $6.60 \mathrm{E}-05$ & 4.91E-04 \\
\hline $\mathrm{U}-234$ & $\mathrm{uCi} / \mathrm{g}$ & 5.09E-04 & $7.68 \mathrm{E}-05$ & 5.72E-04 \\
\hline U-235 & $\mathrm{uCi} / \mathrm{g}$ & $1.78 \mathrm{E}-05$ & $2.74 \mathrm{E}-06$ & $2.01 \mathrm{E}-05$ \\
\hline $\mathrm{U}-236$ & $\mathrm{uCi} / \mathrm{g}$ & $2.66 \mathrm{E}-05$ & $3.74 \mathrm{E}-06$ & 2.97E-05 \\
\hline U-238 & $\mathrm{uCi} / \mathrm{g}$ & $5.84 \mathrm{E}-04$ & 8.05E-05 & $6.50 \mathrm{E}-04$ \\
\hline Y-90 & $\mathrm{uCi} / \mathrm{g}$ & 7.40E-01 & $3.26 \mathrm{E}-01$ & $1.01 \mathrm{E}+00$ \\
\hline
\end{tabular}


SRNL-STI-2010-00400

September 2, 2010

Statistical Analysis of Tank 19F Floor Sample Results

\begin{tabular}{|l|l|r|r|lr|}
\hline Analyte & Units & Average & Standard Deviation & Upper 95\% Confidence Limit \\
\hline Zn & $\mathrm{Wt} \%$ & $7.20 \mathrm{E}-03$ & $1.40 \mathrm{E}-03$ & $8.35 \mathrm{E}-03$ \\
\hline Zr-93 & $\mathrm{uCi} / \mathrm{g}$ & $1.43 \mathrm{E}-03$ & $8.62 \mathrm{E}-04$ & $2.14 \mathrm{E}-03$ \\
\hline
\end{tabular}

Table 4. Current Scrape Sample Constituents with 2 or 3 Repeat

Measurements Below Detection Limits

\begin{tabular}{|l|l|l|c|}
\hline \multicolumn{2}{|c|}{ Radiological Constituents } & \multicolumn{2}{c|}{ Elemental Constituents } \\
\hline \multicolumn{1}{|c|}{ Analyte } & Number of Samples & \multicolumn{1}{c|}{ Analyte } & Number of Samples \\
\hline Ac-227 & 6 & Ag & 6 \\
\hline Al-26 & 6 & As & 6 \\
\hline Am-242m & 6 & B & 6 \\
\hline Cf-249 & 6 & Be & 6 \\
\hline Cm-243 & 6 & Ce & 6 \\
\hline Cm-245 & 6 & Cu & 6 \\
\hline Cm-247 & 6 & Gd & 6 \\
\hline Cm-248 & 6 & La & 6 \\
\hline Eu-152 & 1 & Li & 6 \\
\hline Eu-152 & 5 & Mo & 6 \\
\hline Eu-155 & 6 & Ni & 6 \\
\hline H-3 & 6 & P & 6 \\
\hline I-129 & 6 & Pb & 6 \\
\hline Ni-59 & 6 & S & 6 \\
\hline Ni-63 & 6 & Sb & 6 \\
\hline Pa-231 & 6 & Se & 6 \\
\hline Pm-147 & 6 & U & 6 \\
\hline Pu-242 & 6 & V & \\
\hline Pu-244 & 6 & & \\
\hline Ra-226 & 6 & & \\
\hline Se-79 & 6 & & \\
\hline Th-229 & 6 & & \\
\hline Th-230 & 6 & & \\
\hline U-233 & 6 & & \\
\hline
\end{tabular}


Statistical Analysis of Tank 19F Floor Sample Results

This page intentionally left blank 


\subsection{RESULTS AND CONCLUSIONS}

The Mantis sample results were significantly different from the current floor samples. Considering that the Mantis samples were taken prior to cleaning and prior to evaporation and in view of the statistical results, the current scrape samples were used to characterize the material remaining in the tank.

The characterization of Tank 19F floor is fully supported by the current scrape samples. Within each hemisphere, inner and outer regions were sampled, resulting in eight samples. Six samples were analyzed and two samples were archived. Statistical models were used for significance testing of the inner and outer region nested within hemispheres, hemisphere differences, and also for scrape versus Mantis sample results.

Determined from over 150 comparisons, the current scrape sample characterization data representing spatial areas on the tank floor showed significant differences for only two constituents: $\mathrm{Hg}$ and Fe. The results from the six samples were combined for each constituent. The QA scrape sample data set was not included in estimating the $U C L_{95 \%}$ s since it would have a negligible impact on the results. If further reduction in the upper confidence limits is needed, the archived samples could be analyzed and included in the statistical computations.

Table 5. Tail Probabilities (p values) and Significance Testing for Regional Differences (Inner vs. Outer, North vs. South Hemispheres) using the Current Scrape Samples

\begin{tabular}{|c|c|c|c|c|}
\hline Analyte & $\begin{array}{c}\text { New Scrape } \\
\text { Inner vs. Outer North }\end{array}$ & \begin{tabular}{c|} 
New Scrape \\
Inner vs. Outer South
\end{tabular} & $\begin{array}{c}\text { New Scrape } \\
\text { North vs. South }\end{array}$ & $\begin{array}{c}\text { New Scrape } \\
\text { Overall }\end{array}$ \\
\hline Am-241 & 0.64 & 0.83 & 0.43 & 0.84 \\
\hline Am-243 & 0.64 & 0.90 & 0.38 & 0.83 \\
\hline Ba & $\begin{array}{ll}0.17 \\
\end{array}$ & 0.55 & 0.75 & 0.40 \\
\hline Ba-137m & 0.54 & 0.98 & 0.47 & 0.82 \\
\hline C-14 & 0.85 & 0.66 & 0.78 & 0.94 \\
\hline Cd & 0.92 & 0.63 & 0.66 & 0.92 \\
\hline Cm-244 & 0.49 & 0.57 & 0.83 & 0.77 \\
\hline Co-60 & 0.54 & 0.75 & 0.69 & 0.85 \\
\hline $\mathrm{Cr}$ & \begin{tabular}{l|l|}
0.62 \\
\end{tabular} & 0.70 & 0.45 & 0.81 \\
\hline Cs-135 & \begin{tabular}{l|l|}
0.07 \\
\end{tabular} & 0.76 & 0.39 & 0.16 \\
\hline Cs-137 & 0.54 & 0.98 & 0.47 & 0.82 \\
\hline Eu-154 & 0.50 & 0.90 & 0.34 & 0.72 \\
\hline Fe & ( In> Out) 0.00 & 0.06 & 0.80 & 0.01 \\
\hline $\mathrm{Hg}$ & \begin{tabular}{l|l|}
0.82 \\
\end{tabular} & 0.76 & $(\mathrm{~N}>\mathrm{S}) 0.01$ & 0.27 \\
\hline I-129 & \begin{tabular}{l|l}
0.87 \\
\end{tabular} & 0.84 & 0.88 & 0.99 \\
\hline Mn & \begin{tabular}{l|l}
0.97 \\
\end{tabular} & 0.80 & 0.92 & 0.99 \\
\hline Nitrate & \begin{tabular}{l|l}
0.72 \\
\end{tabular} & 0.57 & 0.11 & 0.50 \\
\hline Np-237 & \begin{tabular}{l|l}
0.63 \\
\end{tabular} & 0.74 & 0.34 & 0.78 \\
\hline Pu-238 & \begin{tabular}{l|l}
0.66 \\
\end{tabular} & 0.61 & 0.35 & 0.75 \\
\hline \begin{tabular}{|l} 
Pu-239 \\
\end{tabular} & \begin{tabular}{|c|}
0.91 \\
\end{tabular} & 0.54 & 0.76 & 0.88 \\
\hline
\end{tabular}


SRNL-STI-2010-00400

Statistical Analysis of Tank 19F Floor Sample Results

September 2, 2010

\begin{tabular}{|l|r|r|r|r|}
\hline \multicolumn{1}{|c|}{ Analyte } & $\begin{array}{c}\text { New Scrape } \\
\text { Inner vs. Outer North }\end{array}$ & $\begin{array}{c}\text { New Scrape } \\
\text { Inner vs. Outer South }\end{array}$ & $\begin{array}{c}\text { New Scrape } \\
\text { North vs. South }\end{array}$ & $\begin{array}{c}\text { New Scrape } \\
\text { Overall }\end{array}$ \\
\hline Pu-240 & 0.83 & 0.63 & 0.81 & 0.93 \\
\hline Pu-241 & 0.98 & 0.57 & 0.78 & 0.91 \\
\hline Ra-226 & 0.98 & 0.99 & 0.66 & 0.99 \\
\hline Sb-126 & 0.46 & 0.16 & 0.10 & 0.18 \\
\hline Sb-126m & 0.18 & 0.15 & 0.08 & 0.11 \\
\hline Sm-151 & 0.49 & 0.54 & 0.52 & 0.70 \\
\hline Sn-126 & 0.18 & 0.15 & 0.08 & 0.11 \\
\hline Sr-90 & 0.84 & 0.08 & 0.65 & 0.20 \\
\hline Tc-99 & 0.38 & 0.80 & 0.90 & 0.75 \\
\hline Ti & 0.27 & 0.72 & 0.50 & 0.53 \\
\hline U-232 & 0.62 & 0.70 & 0.42 & 0.80 \\
\hline U-233 & 0.67 & 0.71 & 0.36 & 0.80 \\
\hline U-234 & 0.52 & 0.69 & 0.80 & 0.84 \\
\hline U-235 & 0.91 & 0.75 & 0.79 & 0.97 \\
\hline U-236 & 0.27 & 0.67 & 0.67 & 0.56 \\
\hline U-238 & 0.60 & 0.76 & 0.77 & 0.90 \\
\hline Y-90 & 0.84 & 0.08 & 0.65 & 0.20 \\
\hline Zn & 0.45 & 0.25 & 0.43 & 0.43 \\
\hline
\end{tabular}


Table 6. Tail Probabilities (p values) and Significance Testing for Mantis, Scrape Sample and Hemisphere Differences

P $\leq 0.05$ indicates significance at the 5\% level (95\% Confidence) (red)

\begin{tabular}{|c|c|c|c|c|}
\hline Analyte & $\begin{array}{l}\text { New Scrape vs } \\
\text { Mantis North }\end{array}$ & $\begin{array}{l}\text { New Scrape vs } \\
\text { Mantis South }\end{array}$ & $\begin{array}{c}\text { New Scrape vs } \\
\text { Mantis N S } \\
\text { Combined }\end{array}$ & $\begin{array}{c}\text { New \& Old Scrape } \\
\text { Combined vs Mantis, S Only }\end{array}$ \\
\hline Am-241 & $(\mathrm{Man}>\mathrm{Scr}) 0.00$ & 0.62 & 0.15 & N/A \\
\hline Am-243 & 0.89 & 0.61 & 0.63 & N/A \\
\hline $\mathbf{B a}$ & 0.87 & 0.76 & 0.69 & N/A \\
\hline Ba-137m & 0.24 & 0.95 & 0.35 & $\mathrm{~N} / \mathrm{A}$ \\
\hline C-14 & 0.38 & 0.50 & 0.19 & N/A \\
\hline Cd & (Man>Scr) 0.01 & 0.37 & 0.30 & N/A \\
\hline Cm-244 & 0.57 & 0.35 & 0.76 & N/A \\
\hline Co-60 & (Man>Scr) 0.04 & 0.46 & 0.37 & N/A \\
\hline $\mathrm{Cr}$ & 0.11 & 0.59 & 0.15 & N/A \\
\hline Cs-135 & $($ Man $>$ Scr $) 0.00$ & 0.01 & (Man>Scr) 0.00 & N/A \\
\hline Cs-137 & 0.29 & 0.94 & 0.41 & 0.71 \\
\hline Eu-154 & (Man> Scr) 0.00 & 0.80 & 0.11 & N/A \\
\hline $\mathbf{F e}$ & 1.00 & 0.97 & 0.97 & N/A \\
\hline Hg & (Man>Scr) 0.05 & 0.28 & 0.16 & N/A \\
\hline I-129 & N/A & $\mathrm{N} / \mathrm{A}$ & 0.01 & N/A \\
\hline Mn & 0.31 & 0.14 & $(\mathrm{Man}<\mathrm{Scr}) 0.045$ & N/A \\
\hline Nitrate & 0.29 & 0.052 & 0.06 & N/A \\
\hline Np-237 & $(\mathrm{Man}<\mathrm{Scr}) 0.01$ & $(\mathrm{Man}<\mathrm{Scr}) 0.00$ & $(\mathrm{Man}<\mathrm{Scr}) 0.00$ & (Scr>Man) 0.01 \\
\hline Pu-238 & 0.37 & $(\mathrm{Man}<\mathrm{Scr}) 0.02$ & 0.06 & (Scr>Man) 0.01 \\
\hline Pu-239 & 0.53 & 0.36 & 0.83 & 0.24 \\
\hline Pu-240 & 0.78 & 0.24 & 0.49 & 0.09 \\
\hline Pu-241 & 0.51 & 0.58 & 0.93 & 0.36 \\
\hline Ra-226 & N/A & $\mathrm{N} / \mathrm{A}$ & 0.46 & N/A \\
\hline Sb-126 & 0.42 & 0.42 & 0.99 & N/A \\
\hline Sb-126m & 0.17 & 0.62 & 0.55 & N/A \\
\hline Sm-151 & (Man>Scr) 0.00 & 0.13 & 0.22 & N/A \\
\hline Sn-126 & 0.17 & 0.62 & 0.55 & N/A \\
\hline Sr-90 & 0.11 & 0.40 & 0.54 & $\mathrm{~N} / \mathrm{A}$ \\
\hline Tc-99 & 0.65 & 0.50 & 0.85 & N/A \\
\hline Ti & 0.06 & (Man>Scr) 0.04 & (Man>Scr) 0.00 & N/A \\
\hline U-232 & 0.42 & 0.08 & $(\mathrm{Man}<\mathrm{Scr}) 0.05$ & N/A \\
\hline U-233 & 0.07 & 0.14 & $(\mathrm{Man}<\mathrm{Scr}) 0.02$ & 0.19 \\
\hline U-234 & $(\mathrm{Man}>\mathrm{Scr}) 0.01$ & 0.15 & 0.42 & N/A \\
\hline U-235 & 0.38 & 0.10 & 0.06 & 0.13 \\
\hline U-236 & 0.35 & 0.12 & 0.06 & 0.22 \\
\hline U-238 & 0.18 & $(\mathrm{Man}<\mathrm{Scr}) 0.05$ & $(\mathrm{Man}<\mathrm{Scr}) 0.02$ & 0.15 \\
\hline Y-90 & 0.11 & 0.40 & 0.54 & N/A \\
\hline Zn & 0.44 & 0.48 & 0.25 & N/A \\
\hline
\end{tabular}


Statistical Analysis of Tank 19F Floor Sample Results

This page intentionally left blank 


\subsection{REFERENCES}

[1] Harris, S.P. and Shine, E.P., Recommendations for Sampling of Tank 19 in F Tank Farm, SRNL-STI-2009-00779, December 2009.

[2] Oji, L.N., Diprete, D.D. and Coleman, C.J., Characterization of Additional Tank 19F Floor Samples, SRNL-STI-2010-00439, August 30, 2010.

[3] Oji, L.N., Diprete, D., and Click, D.R., Characterization Tank 19F Samples, SRNL-STI-2009-00700, Rev. 0, December 17, 2009.

[4] Huff, T. and Thaxton, G.D. Draft of "Tanks 18 and 19 Waste Determination Sample Plan,” LWO-LWE-2008-00186, Revision 2, Savannah River Site, Aiken, SC. (June 22)

[5] Edwards, T.B., “A Decision Support Tool for Planning the Sampling of Tank 19 (U),” WSRC-RP-2001-00781, Revision 0, July 2001.

[6] Statgraphics Centurion XV, Ver. 15.1.03, StatPoint, Inc. 
Statistical Analysis of Tank 19F Floor Sample Results

This page intentionally left blank 
APPENDIX 1. SEQUENCE PLOTS FOR TANK 19F MANTIS AND SCRAPE SAMPLE RESULTS

by Analyte, Hemisphere and Sector (Dried Solids)

\begin{tabular}{|c|c|c|c|}
\hline$\square$ & 1 & Mantis N & \\
\hline $\mathbf{\square}$ & 2 & Mantis S & \\
\hline$\bullet$ & 3 & New Scrape & Inner \\
\hline 0 & 4 & New Scrape & Outer \\
\hline 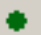 & 5 & Prior Scrape & \\
\hline
\end{tabular}

Am-241, uCi/g

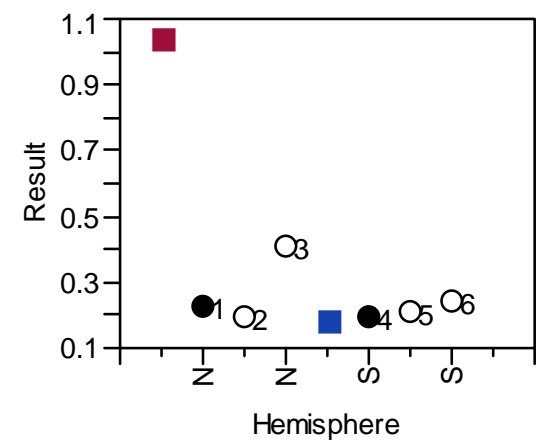

Am-243, uCi/g

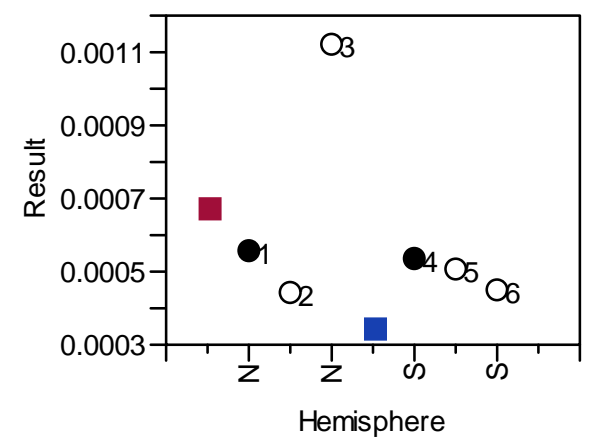

Ba, Wt\%

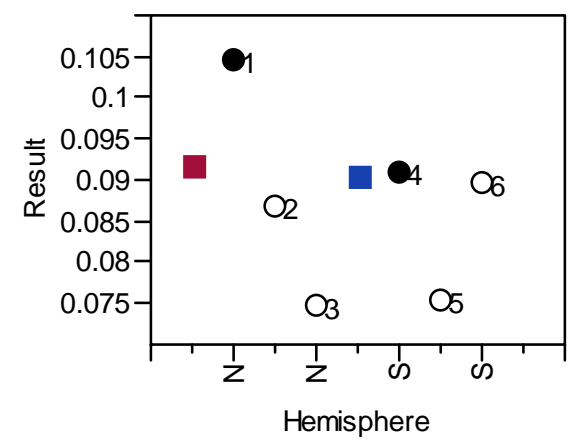

Ba-137m, uCi/g

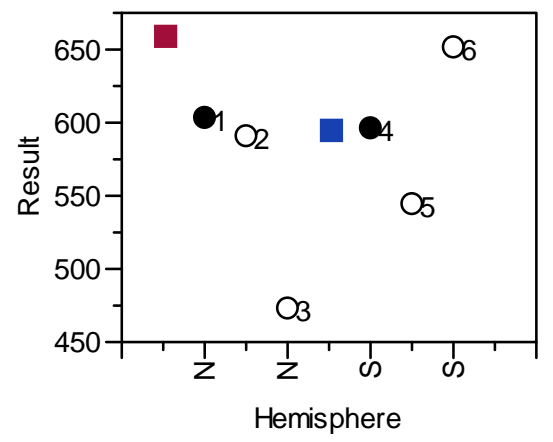

C-14, uCi/g

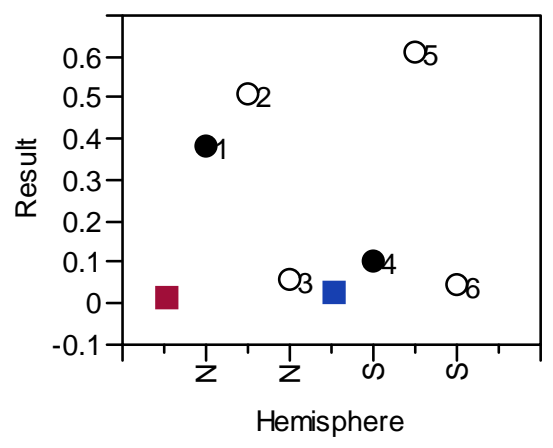

Cd, $\mathrm{Wt} \%$

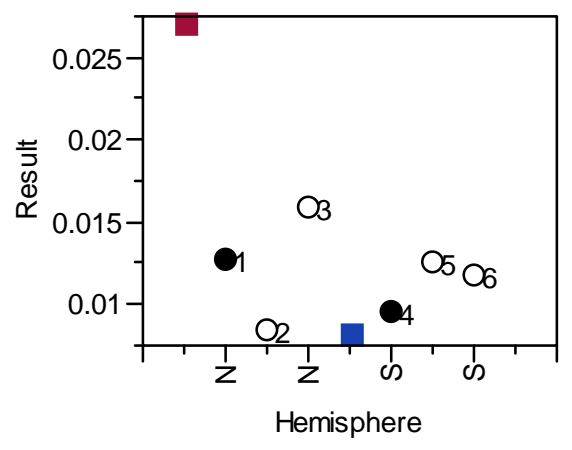


SRNL-STI-2010-00400

Statistical Analysis of Tank 19F Floor Sample Results
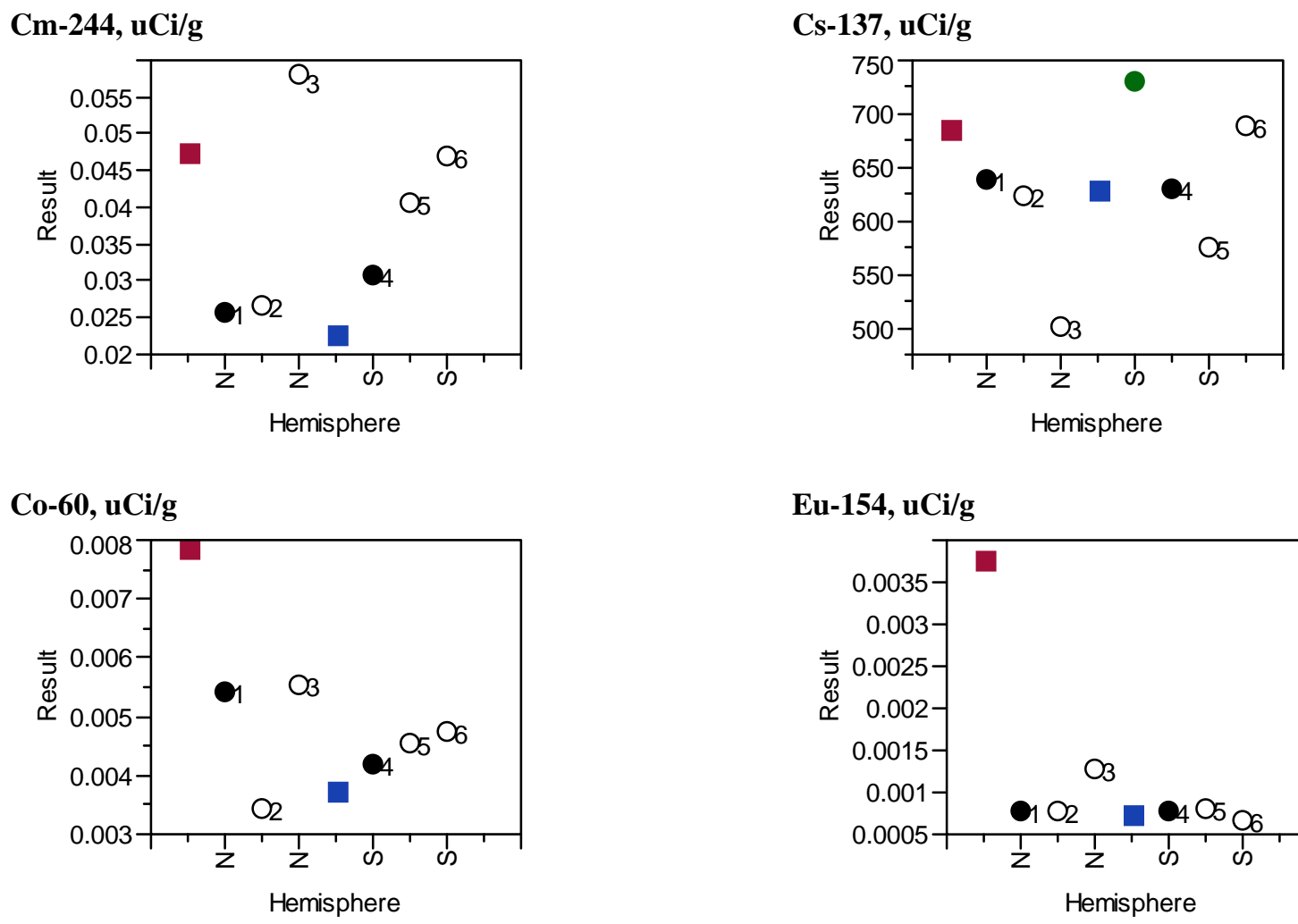

Eu-154, uCi/g
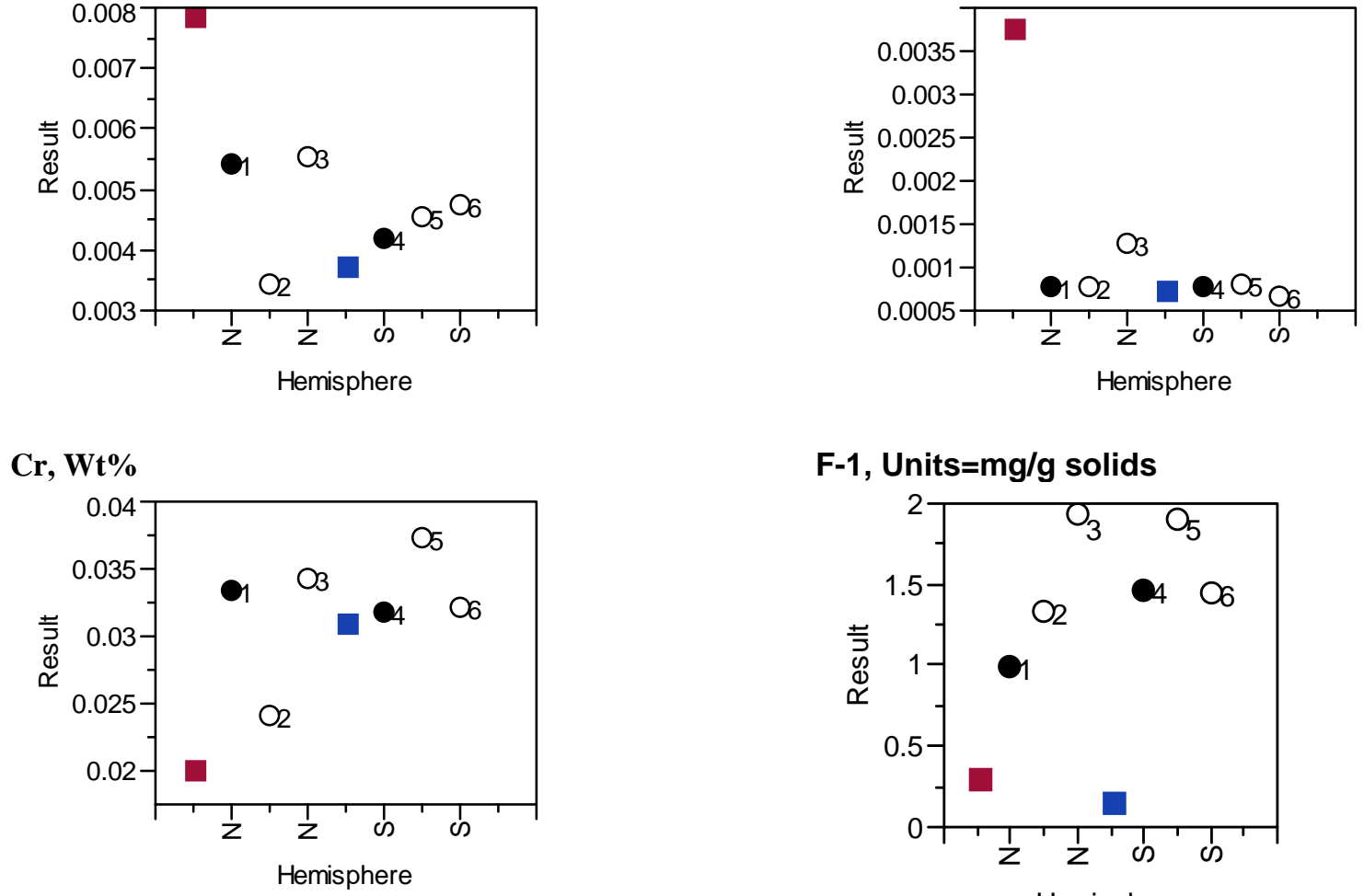

F-1, Units=mg/g solids
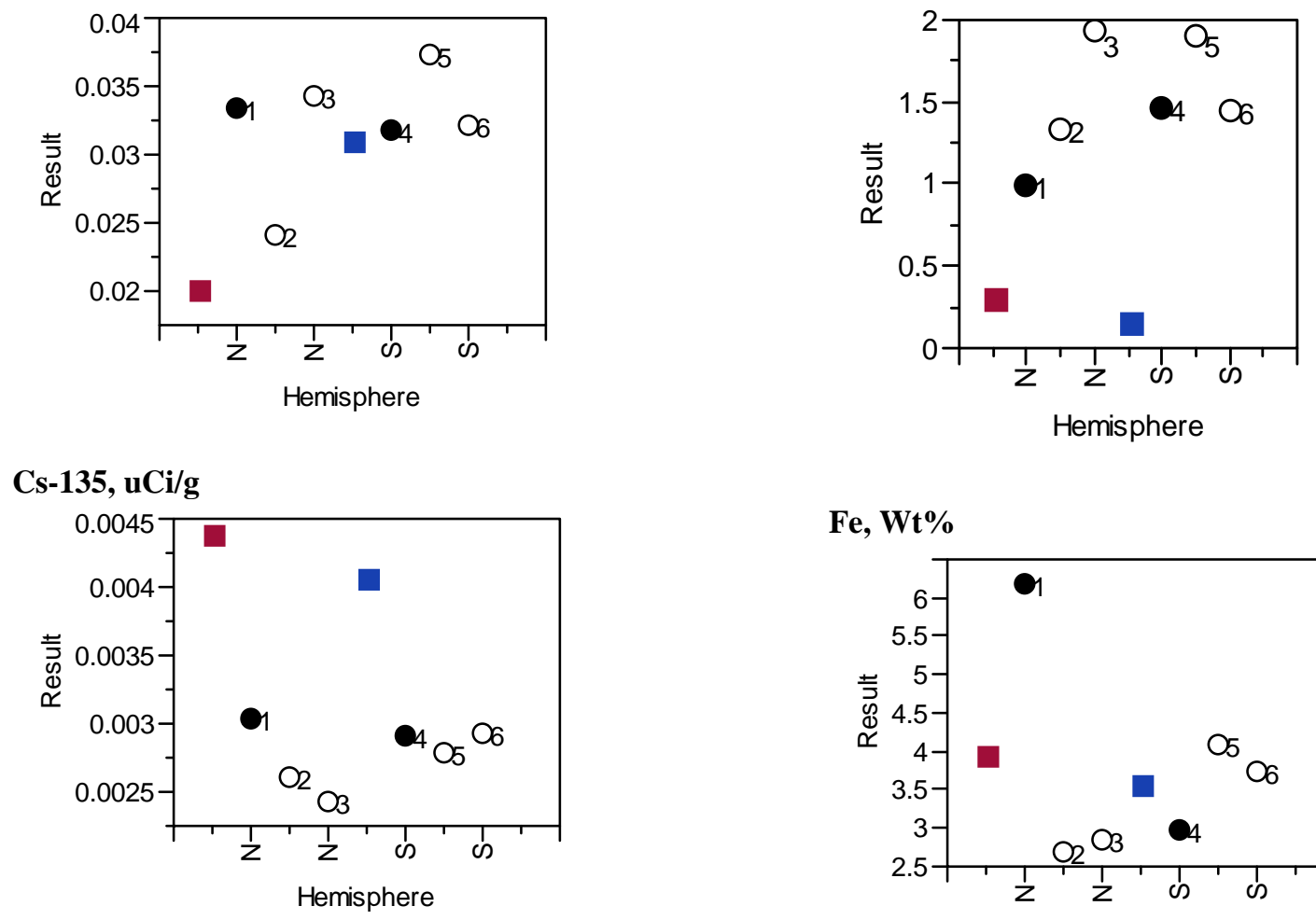

Fe, $\mathrm{Wt} \%$

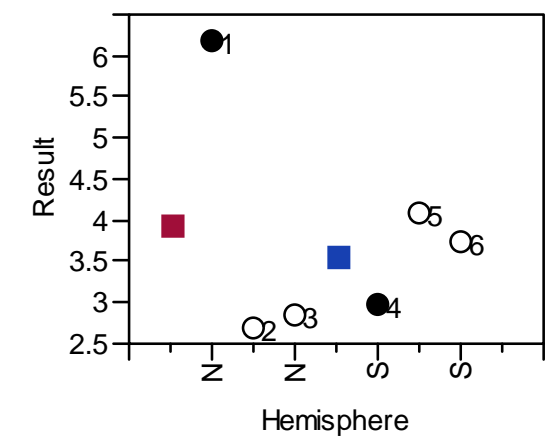


$\mathrm{Hg}, \mathrm{Wt} \%$

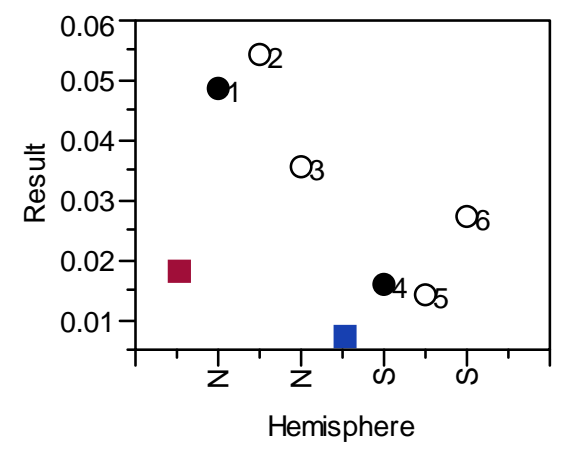

Mn, Wt\%

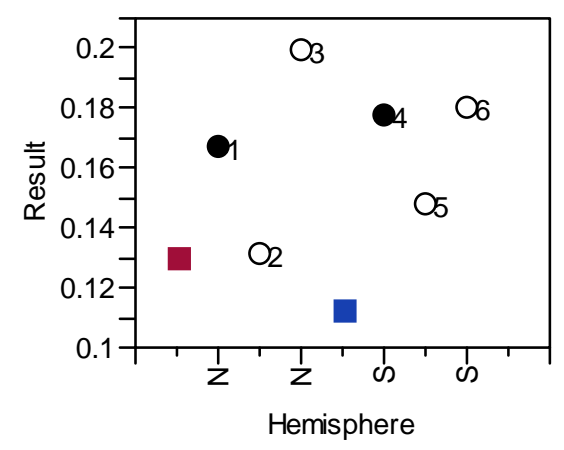

NO2-1, Units $=\mathrm{mg} / \mathrm{g}$ solids

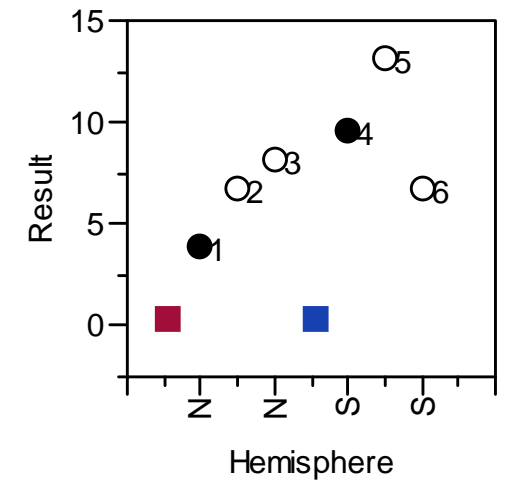

Nitrate, $\mathrm{mg} / \mathrm{g}$

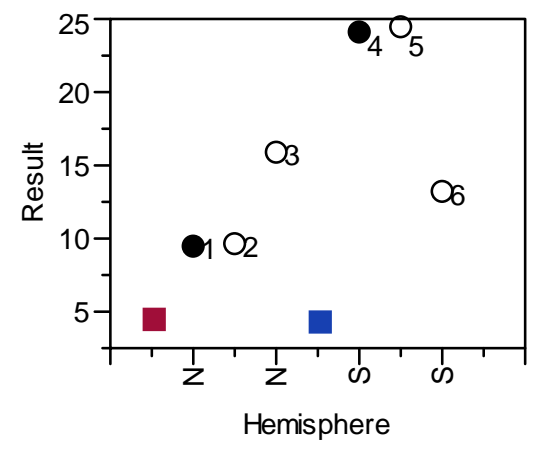

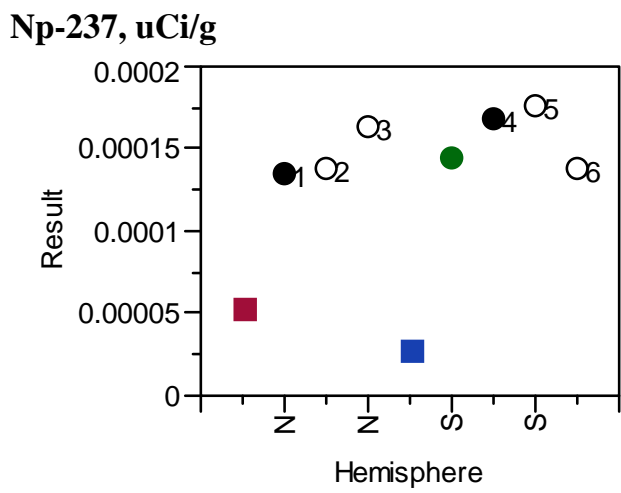

Pu-238, uCi/g

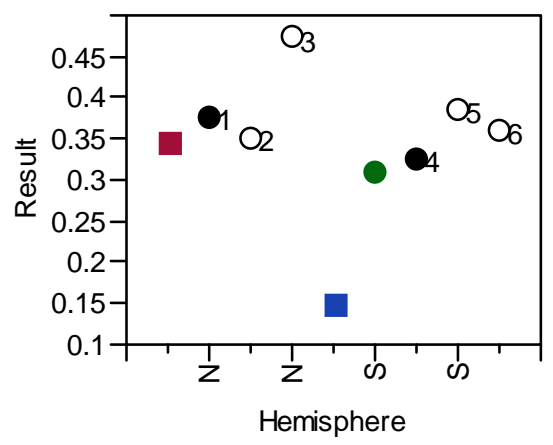

Pu-239, uCi/g

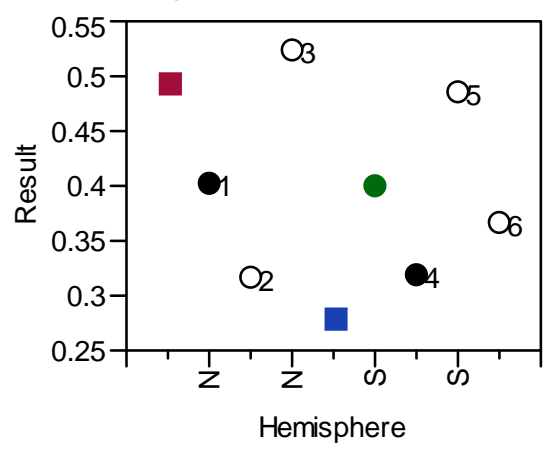

Pu-240, uCi/g

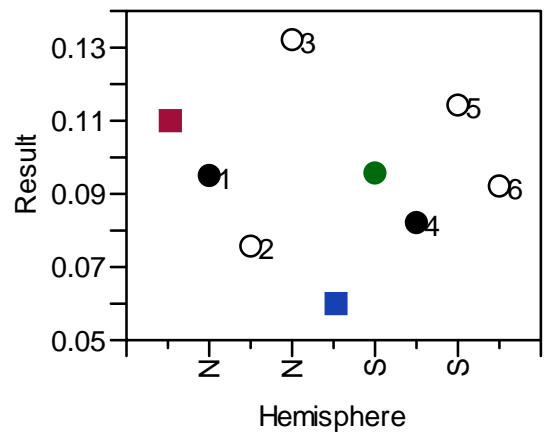


Pu-241, uCi/g

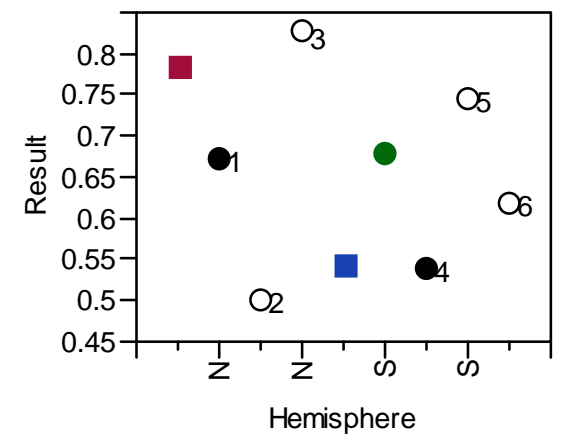

Ra-226, uCi/g

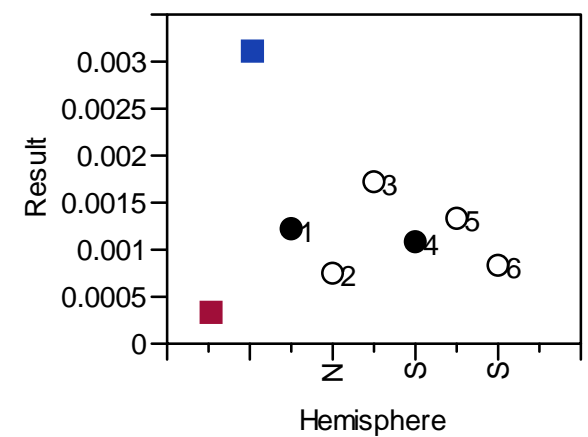

Sb-126, uCi/g

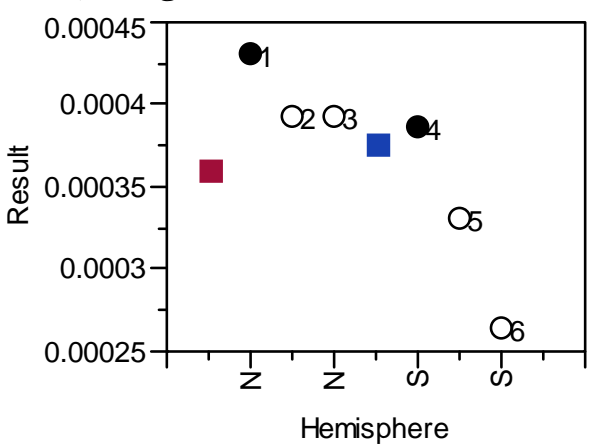

Sb-126m, uCi/g

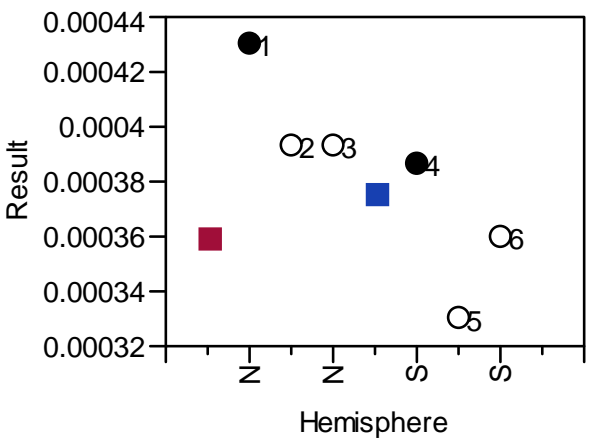

Sm-151, uCi/g

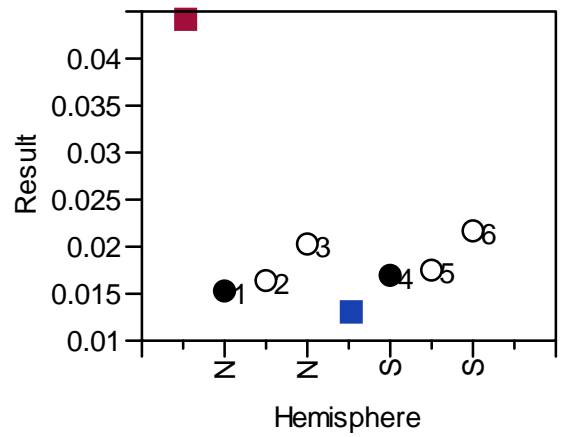

Sn-126, uCi/g
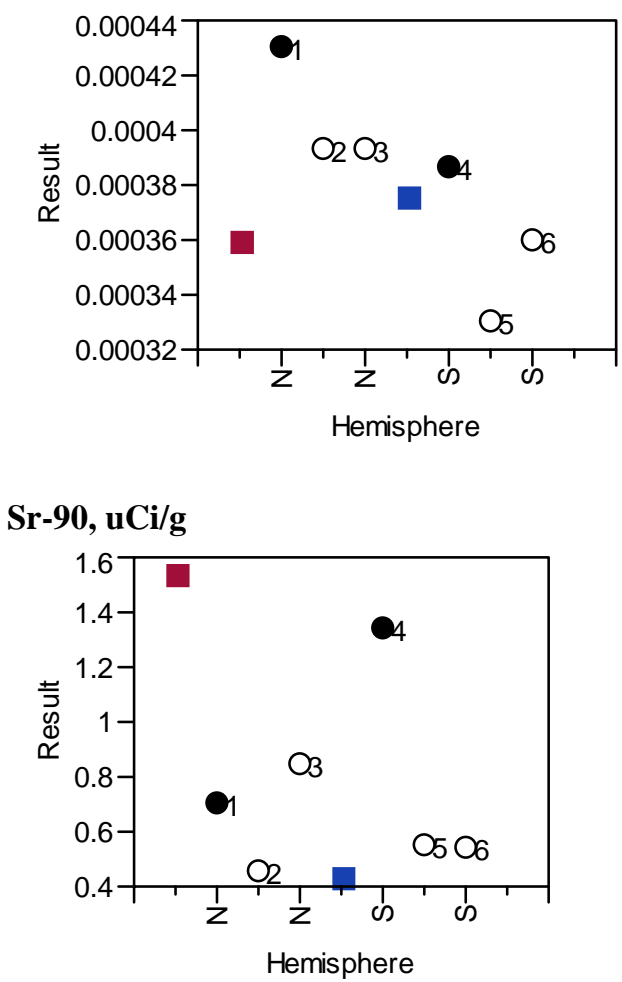

Tc-99, uCi/g

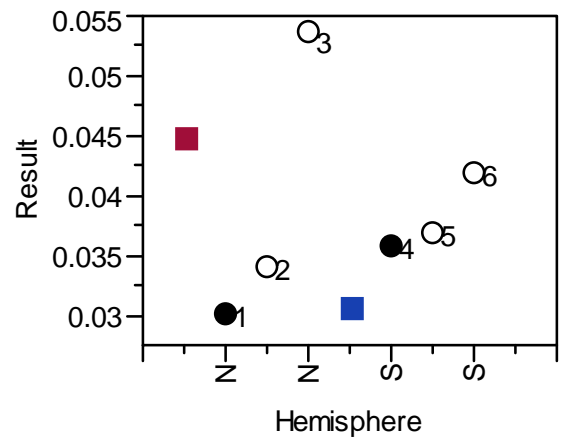


$\mathrm{Ti}, \mathrm{Wt} \%$

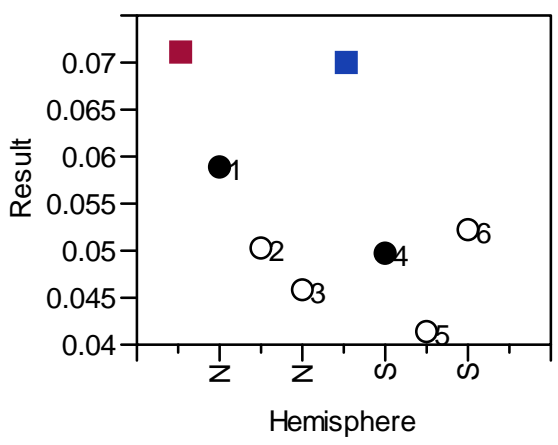

U-232, uCi/g

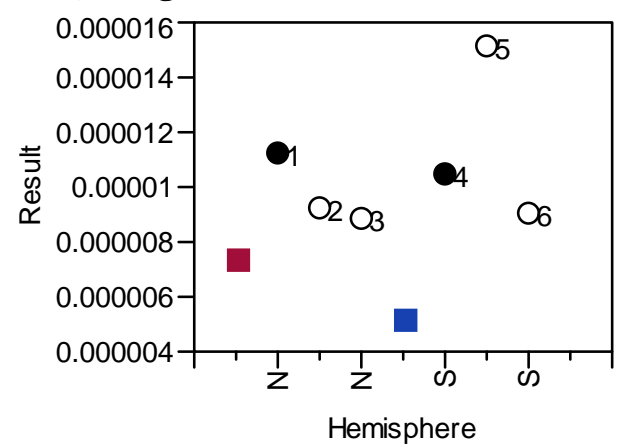

U-233, uCi/g

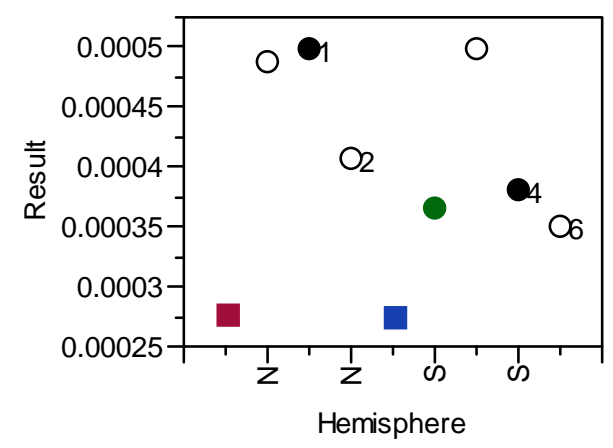

U-234, uCi/g

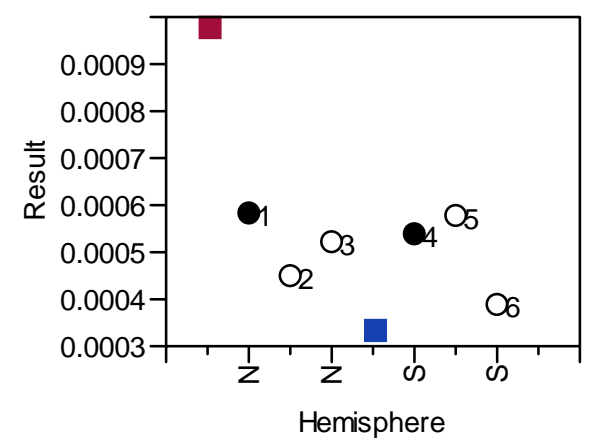

U-235, uCi/g

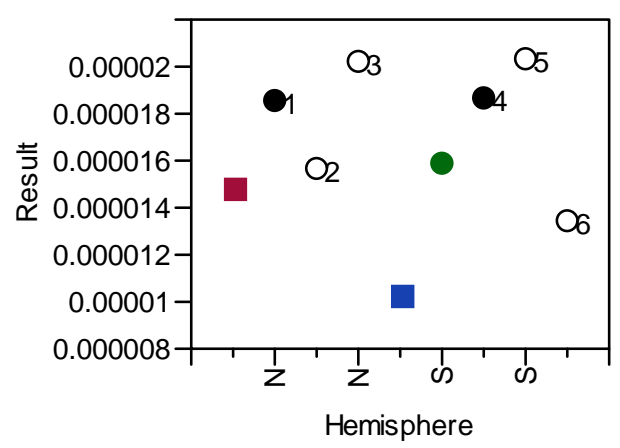

U-236, uCi/g

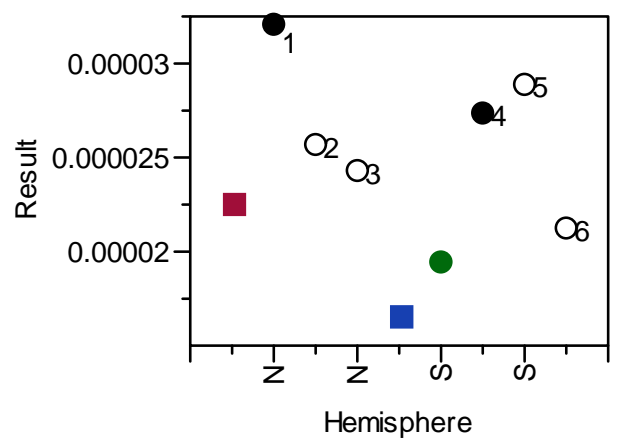

U-238, uCi/g

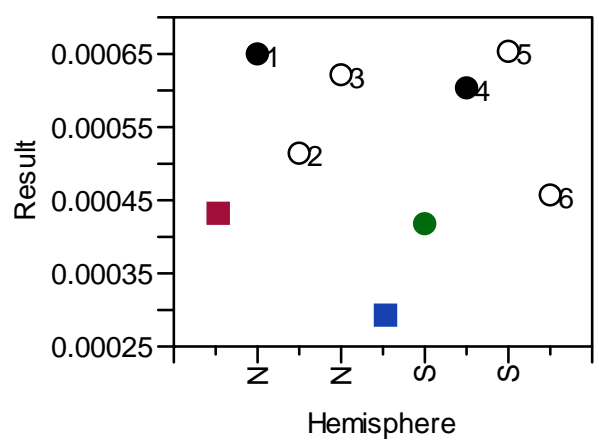

\section{Y-90, uCi/g}

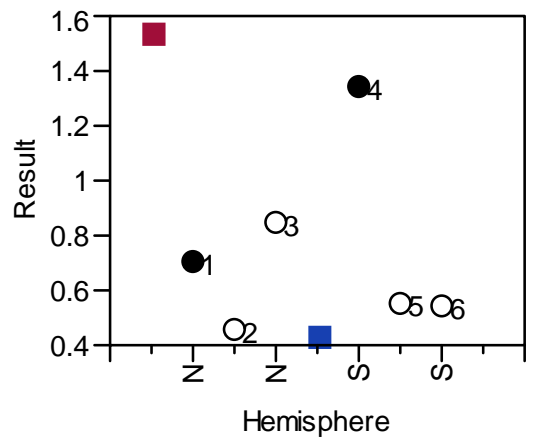


Statistical Analysis of Tank 19F Floor Sample Results

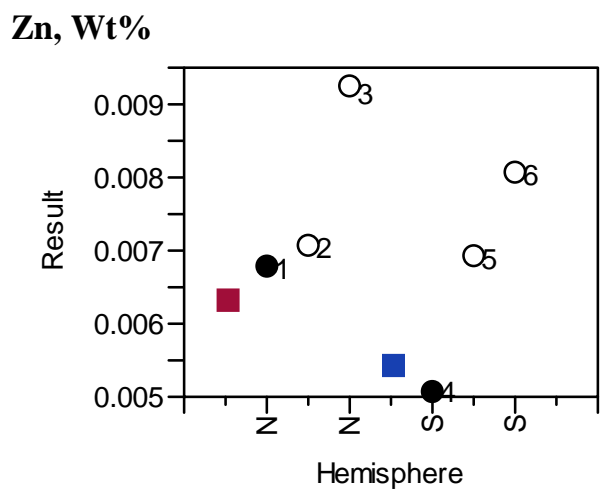




\section{APPENDIX 2. 3-SIGMA PLOTS FOR TANK 19F MANTIS AND SCRAPE SAMPLE RESULTS NORMALIZED}

by the Current Scrape Sample Mean and Standard Deviation by Analyte (Dried Solids)

Norm Result $(\mathrm{N}=6)=($ Result-Mean $) /($ Std Dev) using the Current Scrape Sample Mean and Standard Deviation

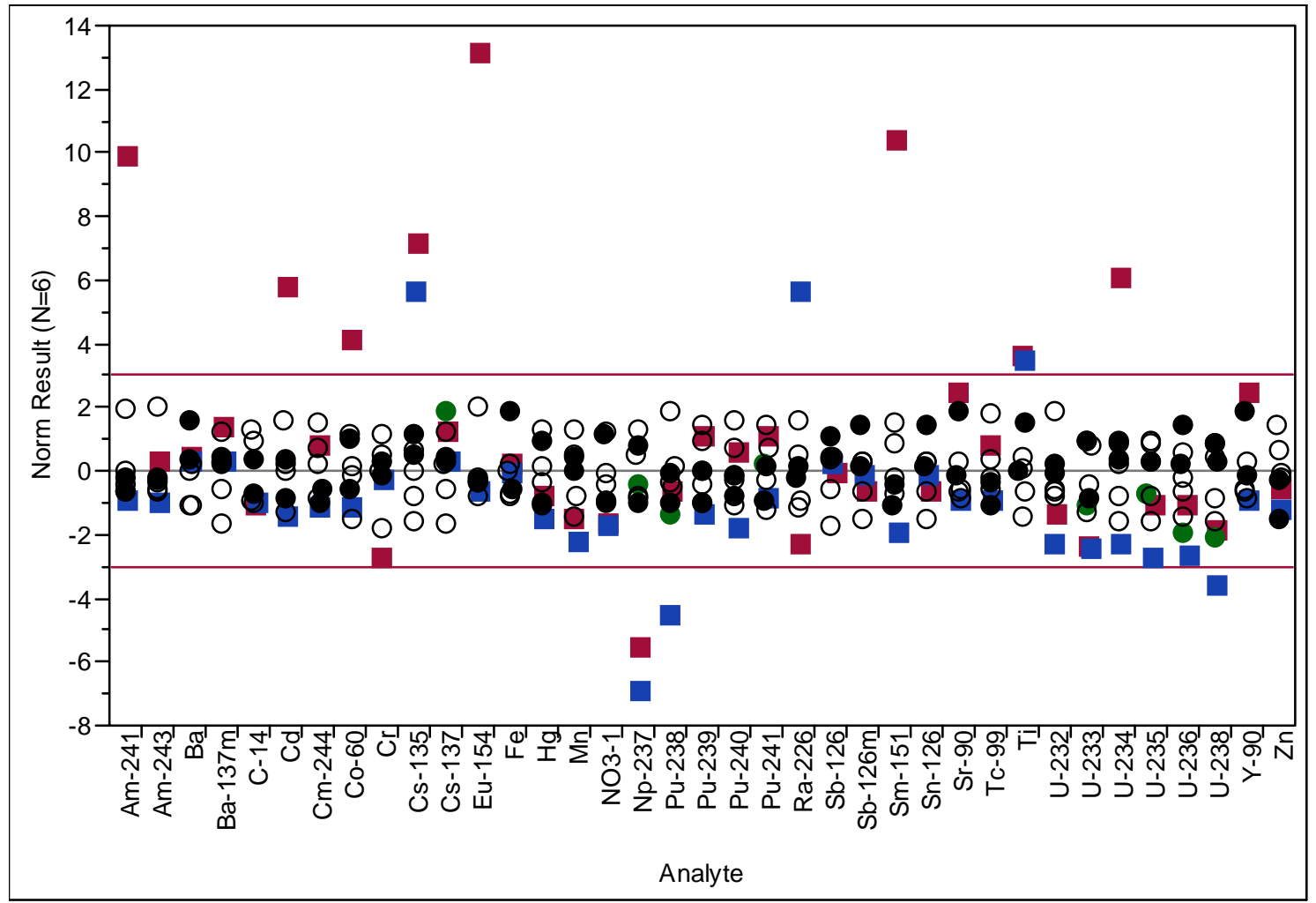

\begin{tabular}{ll|l|l|}
\hline & 1 & Mantis $N$ & \\
\hline$\square$ & 2 & Mantis S & \\
\hline$*$ & 3 & New Scrape & Inner \\
\hline 0 & 4 & New Scrape & Outer \\
\hline$*$ & 5 & Prior Scrape & \\
\hline
\end{tabular}


Statistical Analysis of Tank 19F Floor Sample Results

This page intentionally left blank 
Statistical Analysis of Tank 19F Floor Sample Results

\section{APPENDIX 3A. 3-SIGMA PLOTS FOR TANK 19F CURRENT SCRAPE SAMPLE RESULTS NORMALIZED by its Mean and Standard Deviation by Analyte (Dried Solids)}

Norm Result $(\mathrm{N}=6)=($ Result-Mean $) /($ Std Dev) using the Current Scrape Sample Mean and Standard Deviation

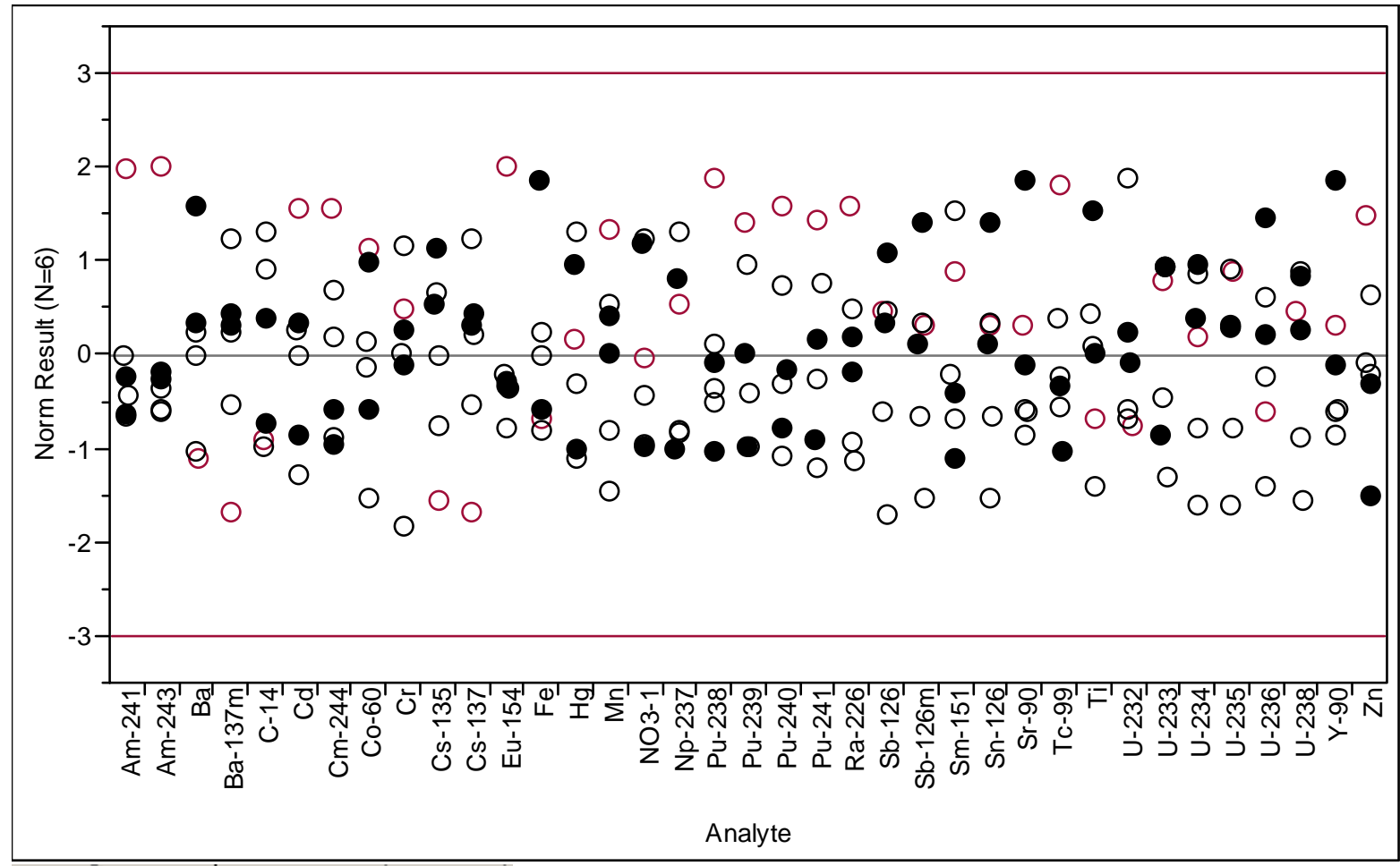

\begin{tabular}{|ll|l|l|}
\hline 0 & & Inner/Outer & Sample \\
\hline 0 & 1 & Outer & 1 \\
\hline+ & 2 & Outer & $2,3,4$ \\
\hline
\end{tabular}




\section{APPENDIX 3B 3-SIGMA PLOTS FOR TANK 19F CURRENT SCRAPE SAMPLE RESULTS NORMALIZED (EXCLUDING SAMPLE 1) by its Mean and Standard Deviation by Analyte (Dried Solids)}

Norm Result (N=5)= (Result-Mean)/(Std Dev) using the Current Scrape Sample Mean and Standard Deviation excluding Sample 1 (Sector 3)

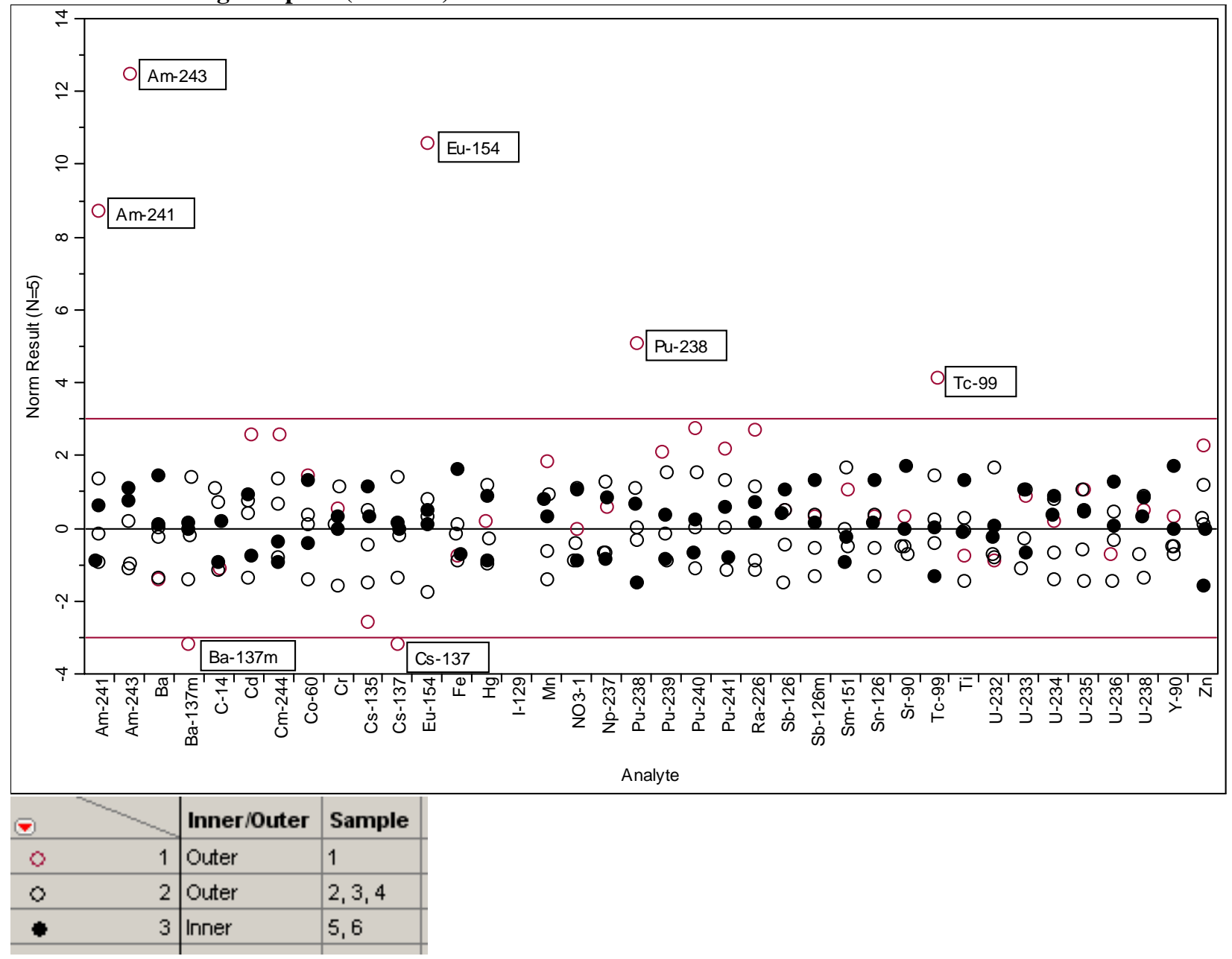


Statistical Analysis of Tank 19F Floor Sample Results

APPENDIX 4. PLOT OF TANK 19F PRIOR SCRAPE (QA SAMPLE) RESULTS VERSUS CURRENT SCRAPE SAMPLES RESULTS

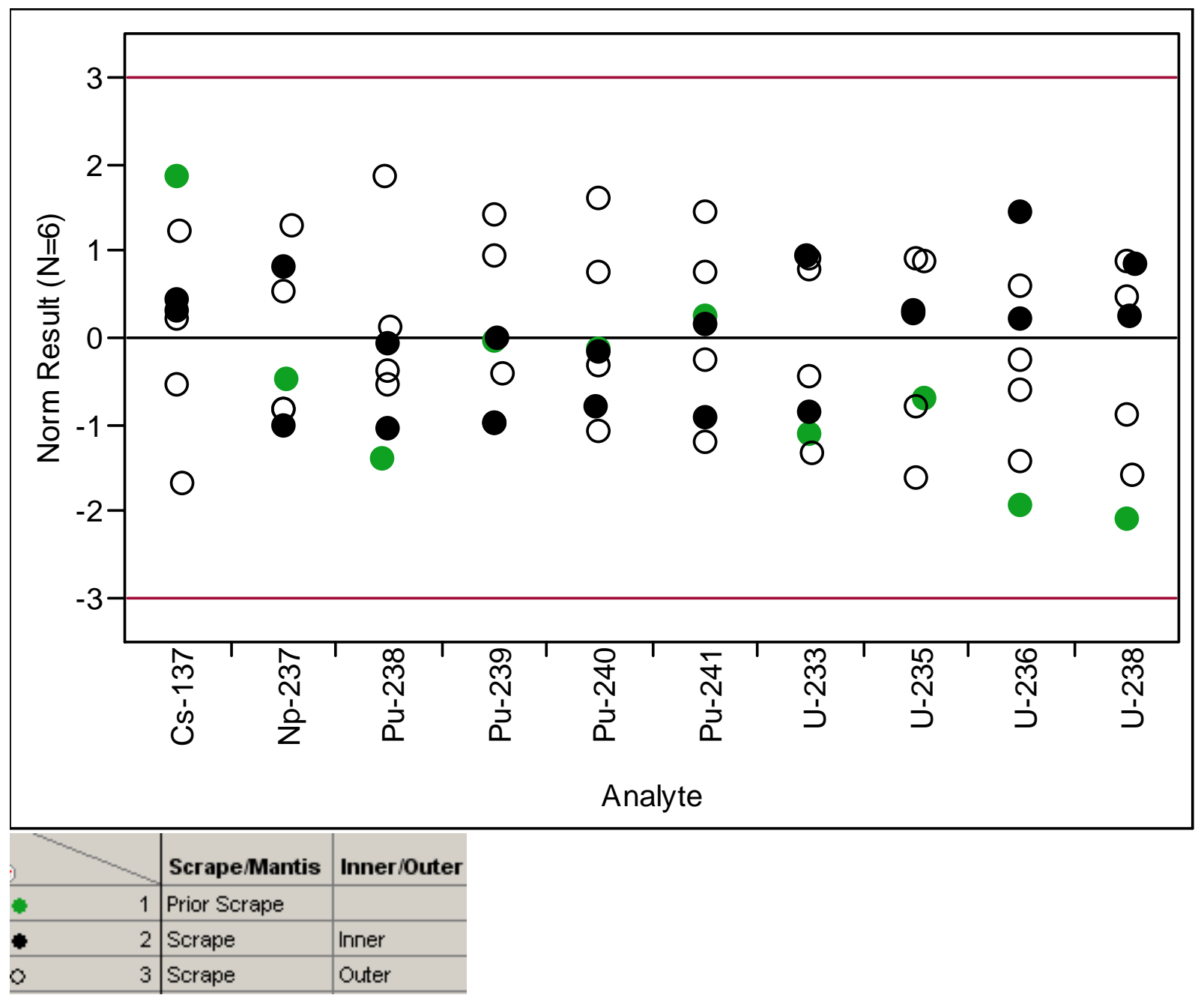


Statistical Analysis of Tank 19F Floor Sample Results

This page intentionally left blank 


\section{APPENDIX 5. TANK 19F SUMMARY STATISTICS AND UPPER 95\% CONFIDENCE LIMITS BY ANALYTE}

Tank 19F, Am-241, uCi/g, Dried Solids

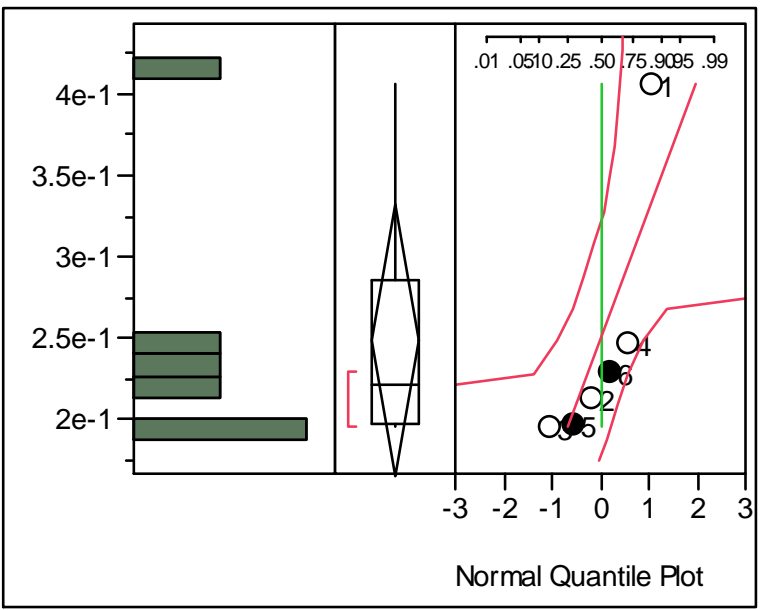

\section{Quantiles}

$\begin{array}{lll}100.0 \% & \text { maximum } & 0.40580 \\ 75.0 \% & \text { quartile } & 0.28630 \\ 50.0 \% & \text { median } & 0.22152 \\ 25.0 \% & \text { quartile } & 0.19706 \\ 0.0 \% & \text { minimum } & 0.19623\end{array}$

Moments

Mean

Std Dev

Std Err Mean

upper $95 \%$ Mean

lower 95\% Mean

$\mathrm{N}$
Tank 19F, Am-243, uCi/g, Dried Solids

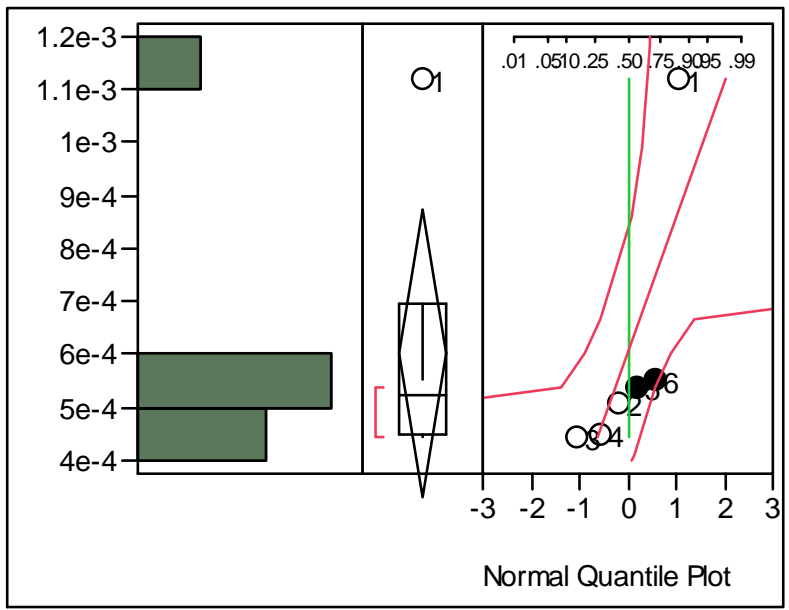

\section{Quantiles}

$\begin{array}{lll}100.0 \% & \text { maximum } & 0.00112 \\ 75.0 \% & \text { quartile } & 0.00070 \\ 50.0 \% & \text { median } & 0.00052 \\ 25.0 \% & \text { quartile } & 0.00045 \\ 0.0 \% & \text { minimum } & 0.00044\end{array}$

\section{Moments}

Mean

0.0006033

Std Dev

Std Err Mean

0.0002583

0.0001055

upper $95 \%$ Mean $\quad 0.0008744$

lower 95\% Mean 0.0003322

$\mathrm{N}$

Upper 95\% Confidence Limit

Parameter Estimate

Mean $\quad 0.000603$

Std Dev $\quad 0.000258$
Upper Cl

0.000816

0.00054 
Tank 19F, Ba, Wt\%, Dried Solids

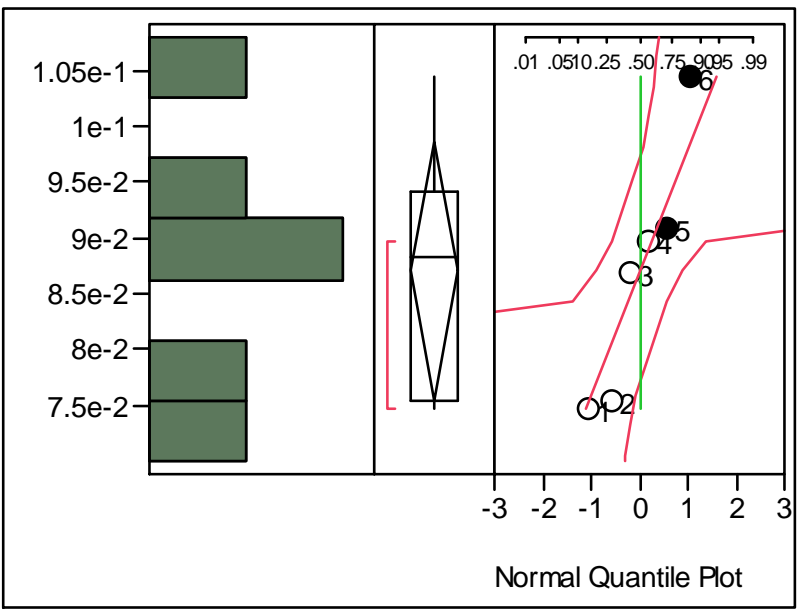

\section{Quantiles}

$\begin{array}{lll}100.0 \% & \text { maximum } & 0.10456 \\ 75.0 \% & \text { quartile } & 0.09424 \\ 50.0 \% & \text { median } & 0.08832 \\ 25.0 \% & \text { quartile } & 0.07529 \\ 0.0 \% & \text { minimum } & 0.07475\end{array}$

\section{Moments}

\section{Mean}

Std Dev

Std Err Mean

upper $95 \%$ Mean

lower 95\% Mean

$\mathrm{N}$

Upper 95\% Confidence Limit

Parameter

Mean

Std Dev

\section{Estimate}

0.087038

0.011074
0.0870379

0.011074

0.004521

0.0986594

0.0754164
Tank 19F, Ba-137m, uCi/g, Dried Solids

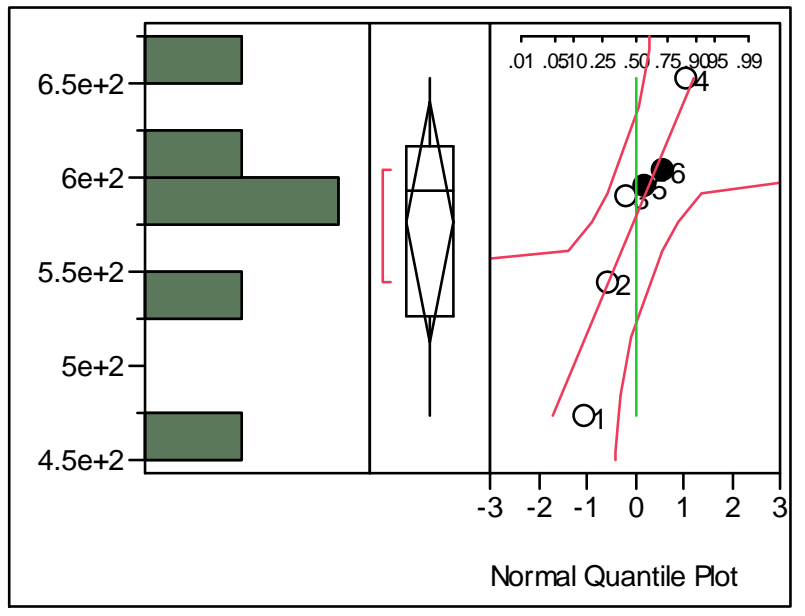

\section{Quantiles}

$\begin{array}{lll}100.0 \% & \text { maximum } & 652.14 \\ 75.0 \% & \text { quartile } & 615.98 \\ 50.0 \% & \text { median } & 593.17 \\ 25.0 \% & \text { quartile } & 526.42 \\ 0.0 \% & \text { minimum } & 474.08\end{array}$

\section{Moments}

$\begin{array}{lr}\text { Mean } & 576.72644 \\ \text { Std Dev } & 60.990042 \\ \text { Std Err Mean } & 24.899081 \\ \text { upper 95\% Mean } & 640.73157 \\ \text { lower 95\% Mean } & 512.72132 \\ \text { N } & 6\end{array}$

Upper 95\% Confidence Limit Parameter Estimate Mean $\quad 576.7264$

Std Dev $\quad 60.99004$
Upper Cl

626.8993 127.4239 
Tank 19F, C-14, uCi/g, Dried Solids

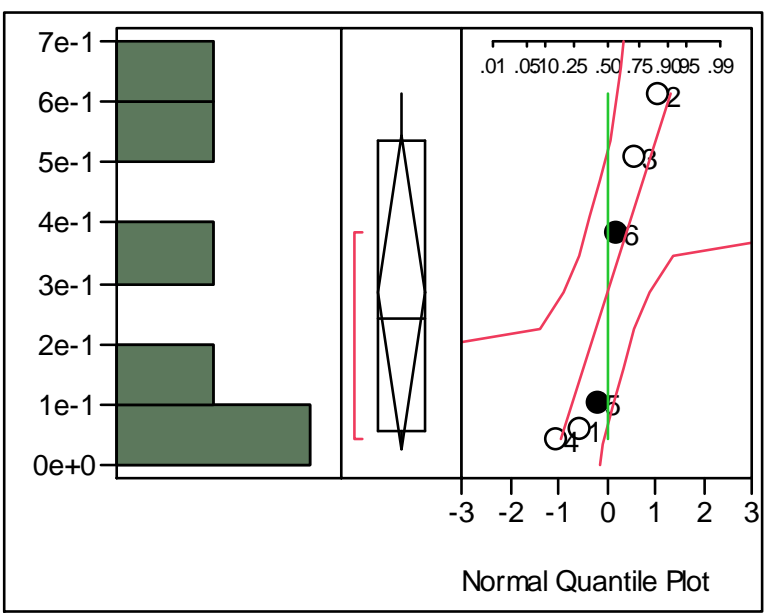

\section{Quantiles}

$\begin{array}{lll}100.0 \% & \text { maximum } & 0.61154 \\ 75.0 \% & \text { quartile } & 0.53682 \\ 50.0 \% & \text { median } & 0.24283 \\ 25.0 \% & \text { quartile } & 0.05619 \\ 0.0 \% & \text { minimum } & 0.04349\end{array}$

\section{Moments}

\section{Mean}

Std Dev

Std Err Mean

upper 95\% Mean

lower 95\% Mean

$\mathrm{N}$

Upper 95\% Confidence Limit

Parameter

Mean

Std Dev
Estimate

0.285505

0.24879
0.2855047

0.2487901

0.1015681

0.5465939

0.0244155

\section{Tank 19F, Cd, Wt\%, Dried Solids}

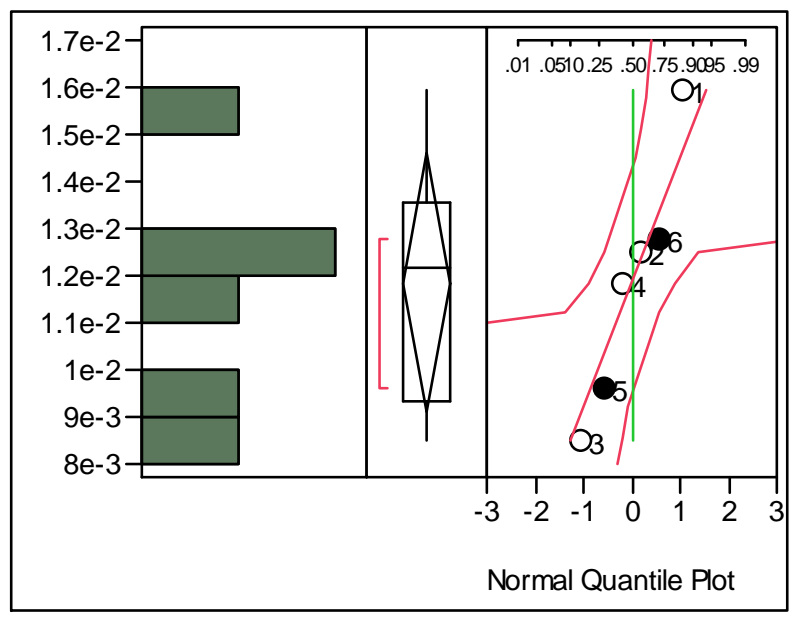

\section{Quantiles}

$\begin{array}{lll}100.0 \% & \text { maximum } & 0.01594 \\ 75.0 \% & \text { quartile } & 0.01356 \\ 50.0 \% & \text { median } & 0.01216 \\ 25.0 \% & \text { quartile } & 0.00931 \\ 0.0 \% & \text { minimum } & 0.00850\end{array}$

\section{Moments}

$\begin{array}{lr}\text { Mean } & 0.011853 \\ \text { Std Dev } & 0.0026223 \\ \text { Std Err Mean } & 0.0010706 \\ \text { upper 95\% Mean } & 0.014605 \\ \text { lower 95\% Mean } & 0.009101 \\ \text { N } & 6\end{array}$

\section{Upper 95\% Confidence Limit}

Parameter Estimate

Mean 0.011853

Std Dev $\quad 0.002622$
Upper Cl

0.01401

0.005479 
Tank 19F, CHLORIDE, Wt\% Dried Solids

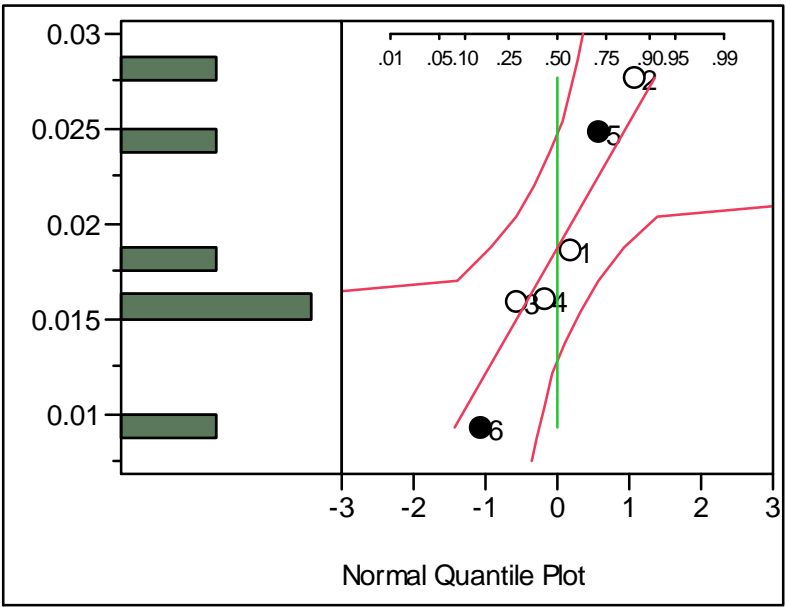

\section{Quantiles}

$\begin{array}{lll}100.0 \% & \text { maximum } & 0.02770 \\ 75.0 \% & \text { quartile } & 0.02553 \\ 50.0 \% & \text { median } & 0.01730 \\ 25.0 \% & \text { quartile } & 0.01425 \\ 0.0 \% & \text { minimum } & 0.00928\end{array}$

\section{Moments}

upper $95 \%$ Mean

\section{Mean}

Std Dev

Std Err Mean

lower 95\% Mean

$\mathrm{N}$

0.0187133

0.0066646

0.0027208

0.0257074

0.0117193

Upper 95\% Confidence Limit

Parameter Estimate

Mean

Std Dev
0.018713

0.006665
Upper Cl

0.024196

0.013924
Tank 19F, Cm-244, uCi/g, Dried Solids

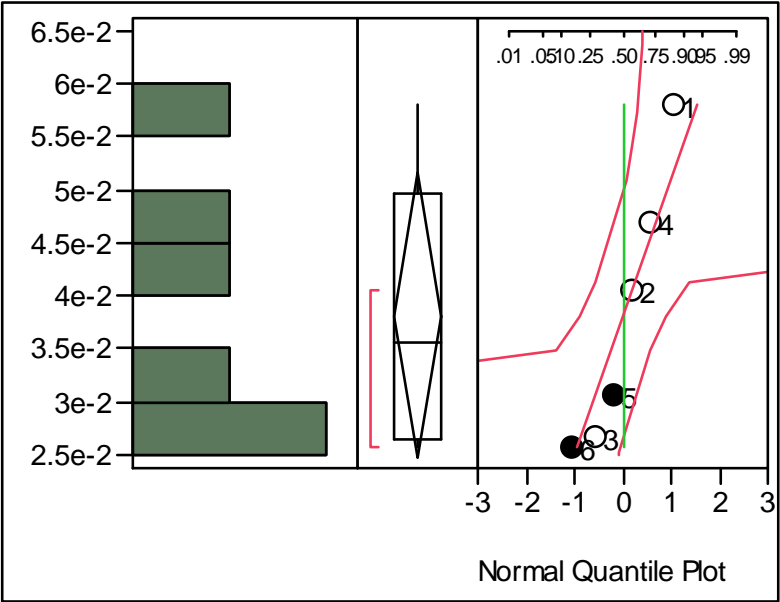

\section{Quantiles}

$\begin{array}{lll}100.0 \% & \text { maximum } & 0.05804 \\ 75.0 \% & \text { quartile } & 0.04976 \\ 50.0 \% & \text { median } & 0.03566 \\ 25.0 \% & \text { quartile } & 0.02645 \\ 0.0 \% & \text { minimum } & 0.02574\end{array}$

\section{Moments}

Mean

0.0381317

Std Dev

0.0128035

Std Err Mean

0.005227

upper $95 \%$ Mean

0.0515682

lower 95\% Mean

$\mathrm{N}$

0.0246953

Upper 95\% Confidence Limit

Parameter Estimate

Mean

0.038132

Std Dev

0.012803

Upper Cl

0.048664

0.02675 
Tank 19F, Co-60, uCi/g, Dried Solids

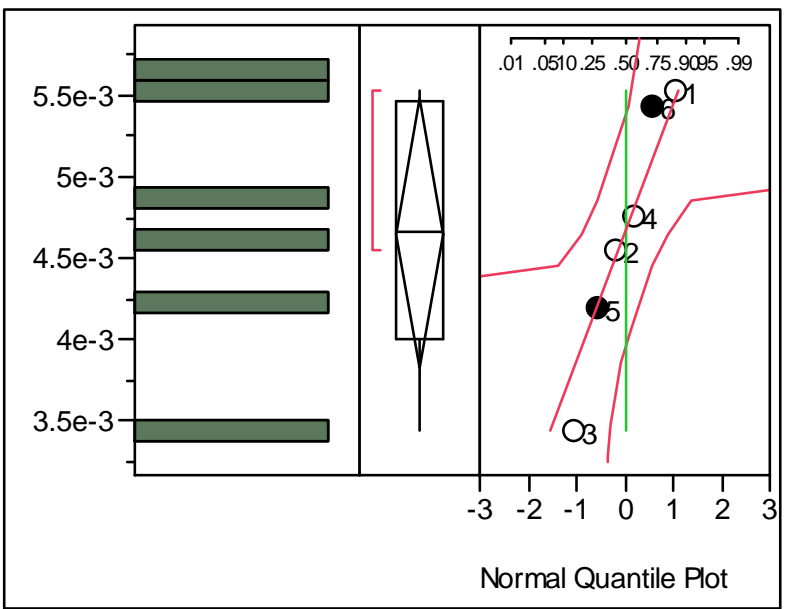

\section{Quantiles}

$\begin{array}{lll}100.0 \% & \text { maximum } & 0.00554 \\ 75.0 \% & \text { quartile } & 0.00546 \\ 50.0 \% & \text { median } & 0.00466 \\ 25.0 \% & \text { quartile } & 0.00400 \\ 0.0 \% & \text { minimum } & 0.00344\end{array}$

\section{Moments}

\section{Mean}

Std Dev

Std Err Mean

upper 95\% Mean

lower 95\% Mean

N

Upper 95\% Confidence Limit

Parameter

Mean

Std Dev

\section{Estimate}

0.004652

0.000785
0.0046519

0.0007853

0.0003206

0.0054761

0.0038278
Tank 19F, Cr, Wt\%, Dried Solids

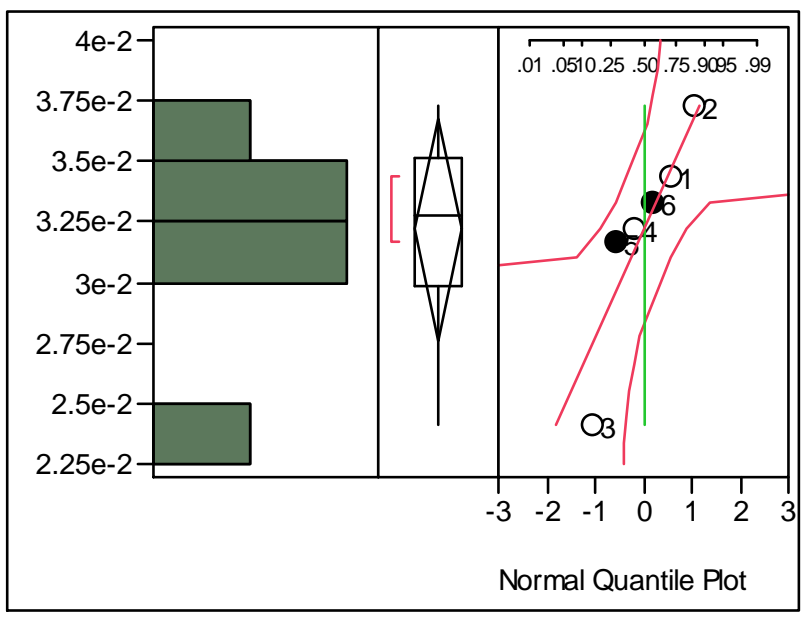

\section{Quantiles}

$\begin{array}{lll}100.0 \% & \text { maximum } & 0.03734 \\ 75.0 \% & \text { quartile } & 0.03510 \\ 50.0 \% & \text { median } & 0.03276 \\ 25.0 \% & \text { quartile } & 0.02982 \\ 0.0 \% & \text { minimum } & 0.02414\end{array}$

\section{Moments}

$\begin{array}{lr}\text { Mean } & 0.0321768 \\ \text { Std Dev } & 0.0044162 \\ \text { Std Err Mean } & 0.0018029 \\ \text { upper 95\% Mean } & 0.0368113 \\ \text { lower 95\% Mean } & 0.0275422 \\ \text { N } & 6\end{array}$

Upper 95\% Confidence Limit

Parameter Estimate

Mean 0.032177

Upper Cl

0.004416
0.03581

0.009227 
Tank 19F, Cs-135, uCi/g, Dried Solids

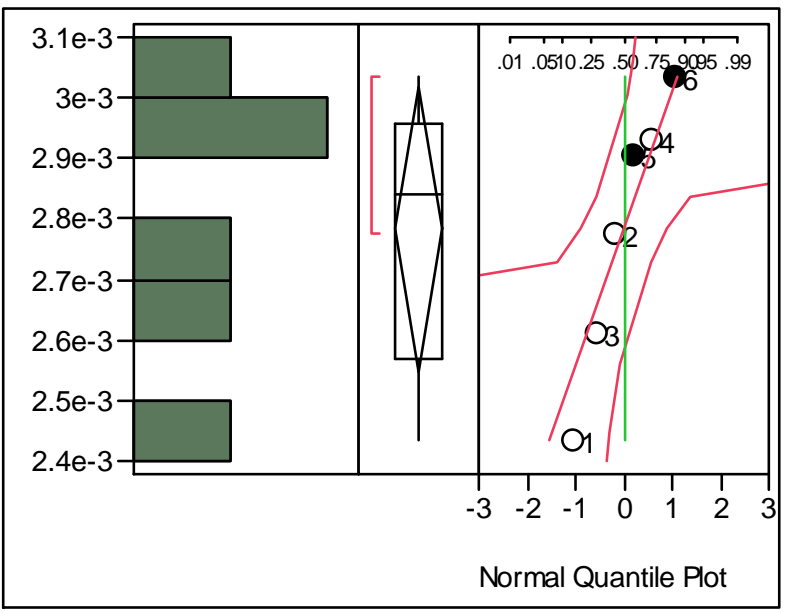

\section{Quantiles}

$\begin{array}{lll}100.0 \% & \text { maximum } & 0.00304 \\ 75.0 \% & \text { quartile } & 0.00296 \\ 50.0 \% & \text { median } & 0.00284 \\ 25.0 \% & \text { quartile } & 0.00257 \\ 0.0 \% & \text { minimum } & 0.00244\end{array}$

\section{Moments}

\section{Mean}

Std Dev

Std Err Mean

upper 95\% Mean

lower 95\% Mean

N

Upper 95\% Confidence Limit

Parameter

Mean

Std Dev
Estimate

0.002782

0.000224
0.0027824

0.0002237

$9.1327 \mathrm{e}-5$

0.0030172

0.0025477
Upper Cl

0.002966

0.000467
Tank 19F, Cs-137, uCi/g, Dried Solids

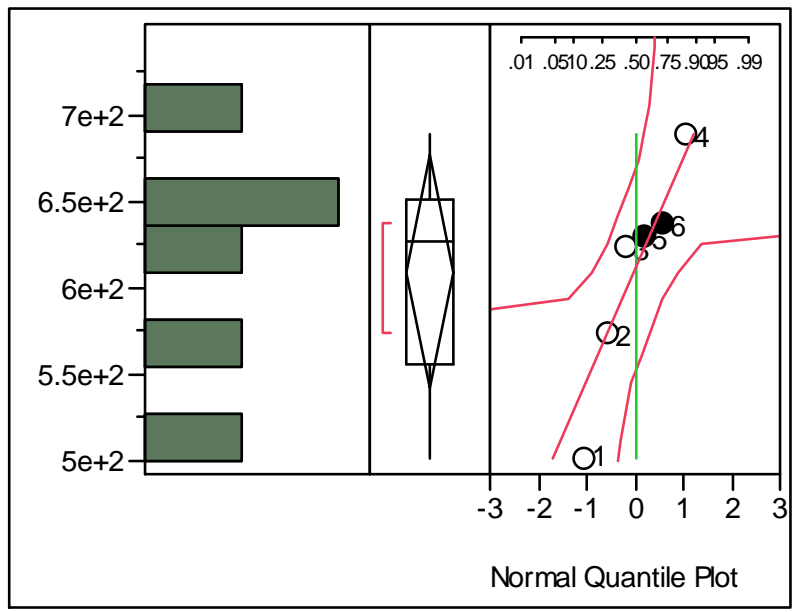

\section{Quantiles}

$\begin{array}{lll}100.0 \% & \text { maximum } & 689.33 \\ 75.0 \% & \text { quartile } & 650.98 \\ 50.0 \% & \text { median } & 626.71 \\ 25.0 \% & \text { quartile } & 556.22 \\ 0.0 \% & \text { minimum } & 500.83\end{array}$

\section{Moments}

$\begin{array}{lr}\text { Mean } & 609.41147 \\ \text { Std Dev } & 64.540511 \\ \text { Std Err Mean } & 26.348553 \\ \text { upper 95\% Mean } & 677.14258 \\ \text { lower 95\% Mean } & 541.68036 \\ \text { N } & 6\end{array}$

Upper 95\% Confidence Limit Parameter Estimate Mean 609.4115

Upper Cl
Std Dev

64.54051
662.5051

134.8417 
Tank 19F, Eu-154, uCi/g, Dried Solids

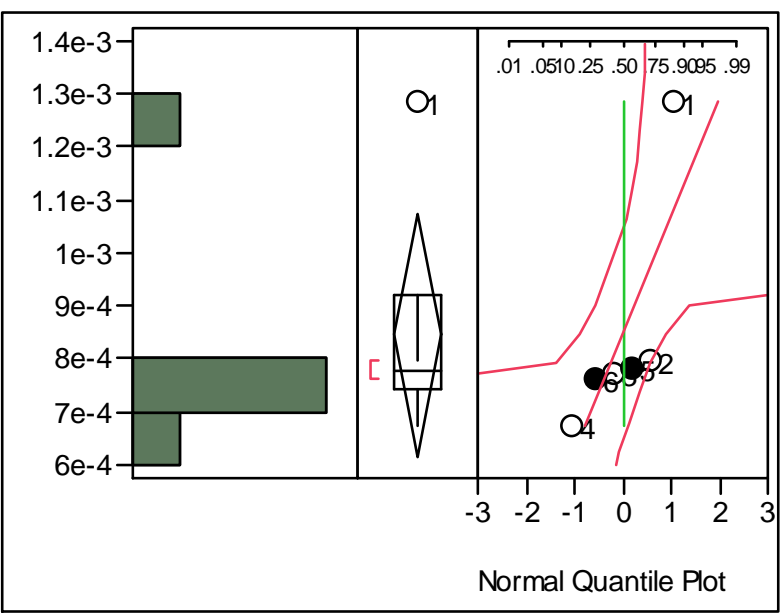

\section{Quantiles}

$\begin{array}{lll}100.0 \% & \text { maximum } & 0.00128 \\ 75.0 \% & \text { quartile } & 0.00092 \\ 50.0 \% & \text { median } & 0.00078 \\ 25.0 \% & \text { quartile } & 0.00074 \\ 0.0 \% & \text { minimum } & 0.00067\end{array}$

\section{Moments}

\section{Mean}

Std Dev

Std Err Mean

upper $95 \%$ Mean

lower 95\% Mean

$\mathrm{N}$

Upper 95\% Confidence Limit

Parameter

Mean

Std Dev

\section{Estimate}

0.000846

0.000219
0.0008459

0.0002195

0.0000896

0.0010762

0.0006156
Tank 19F, Fe, Wt\%, Dried Solids

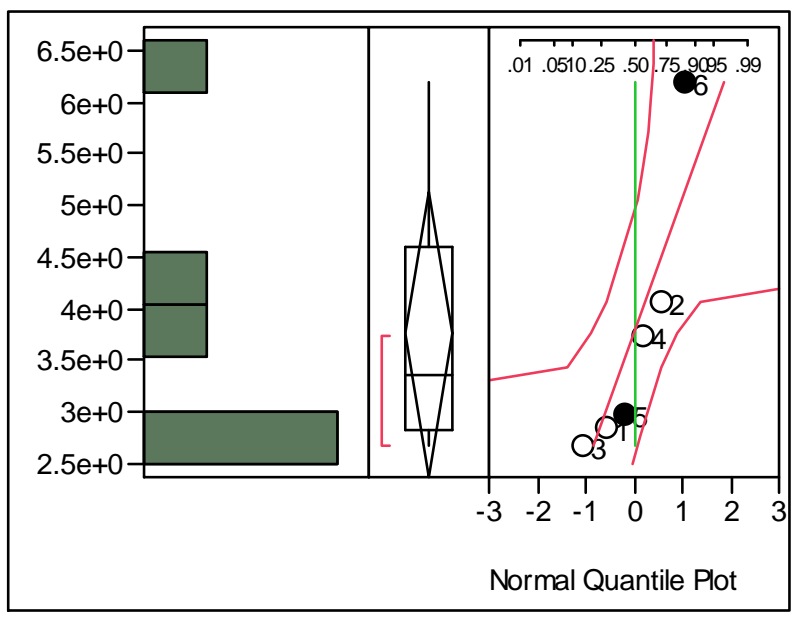

\section{Quantiles}

$\begin{array}{lll}100.0 \% & \text { maximum } & 6.1897 \\ 75.0 \% & \text { quartile } & 4.6033 \\ 50.0 \% & \text { median } & 3.3555 \\ 25.0 \% & \text { quartile } & 2.8204 \\ 0.0 \% & \text { minimum } & 2.6869\end{array}$

\section{Moments}

$\begin{array}{lr}\text { Mean } & 3.7545142 \\ \text { Std Dev } & 1.3090201 \\ \text { Std Err Mean } & 0.5344052 \\ \text { upper 95\% Mean } & 5.1282465 \\ \text { lower 95\% Mean } & 2.380782 \\ \mathrm{~N} & 6\end{array}$

Upper 95\% Confidence Limit

$\begin{array}{lrr}\text { Parameter } & \text { Estimate } & \text { Upper Cl } \\ \text { Mean } & 3.754514 & 4.831367 \\ \text { Std Dev } & 1.30902 & 2.73488\end{array}$


SRNL-STI-2010-00400

Statistical Analysis of Tank 19F Floor Sample Results

Tank 19F, FLUORIDE, Wt\% Dried Solids

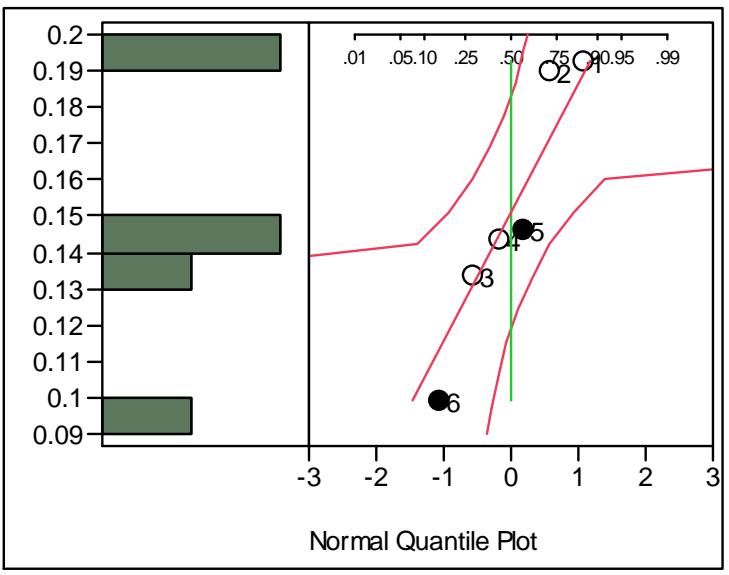

\section{Quantiles}

$\begin{array}{lll}100.0 \% & \text { maximum } & 0.19300 \\ 75.0 \% & \text { quartile } & 0.19075 \\ 50.0 \% & \text { median } & 0.14500 \\ 25.0 \% & \text { quartile } & 0.12528 \\ 0.0 \% & \text { minimum } & 0.09910\end{array}$

\section{Moments}

$\begin{array}{lr}\text { Mean } & 0.1510167 \\ \text { Std Dev } & 0.0356135 \\ \text { Std Err Mean } & 0.0145392 \\ \text { upper 95\% Mean } & 0.1883907 \\ \text { lower 95\% Mean } & 0.1136426 \\ \mathrm{~N} & 6\end{array}$

Upper 95\% Confidence Limit

Parameter

Mean

Estimate

0.151017

0.035614

Upper Cl

0.180314

0.074406
Tank 19F, Hg, Wt\%, Dried Solids

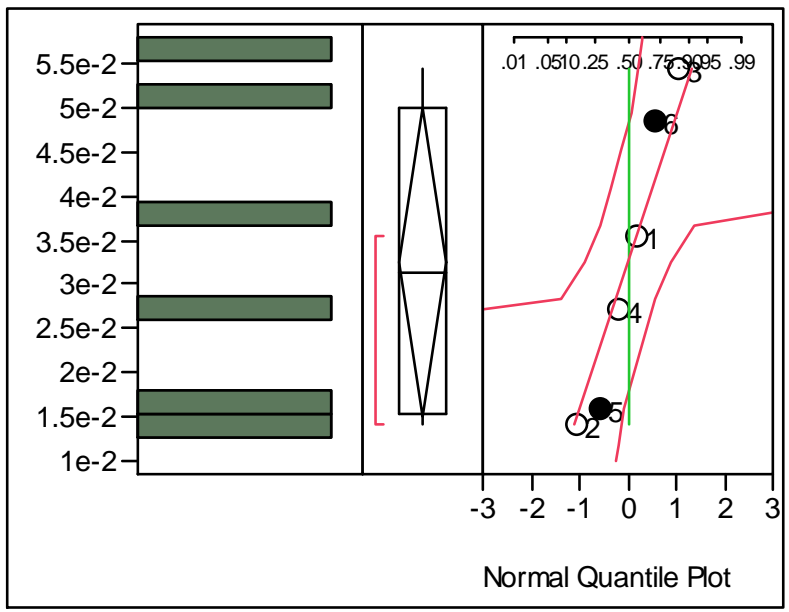

\section{Quantiles}

$\begin{array}{lll}100.0 \% & \text { maximum } & 0.05442 \\ 75.0 \% & \text { quartile } & 0.05009 \\ 50.0 \% & \text { median } & 0.03135 \\ 25.0 \% & \text { quartile } & 0.01540 \\ 0.0 \% & \text { minimum } & 0.01410\end{array}$

\section{Moments}

Mean

0.0326159

Std Dev

0.0166934

Std Err Mean

0.0068151

upper $95 \%$ Mean

0.0501346

lower 95\% Mean

0.0150972

$\mathrm{N}$

$\begin{array}{lcc}\text { Upper 95\% Confidence Limit } & \\ \text { Parameter } & \text { Estimate } & \text { Upper CI } \\ \text { Mean } & 0.032616 & 0.046349 \\ \text { Std Dev } & 0.016693 & 0.034877\end{array}$


Tank 19F, Mn, Wt\%, Dried Solids

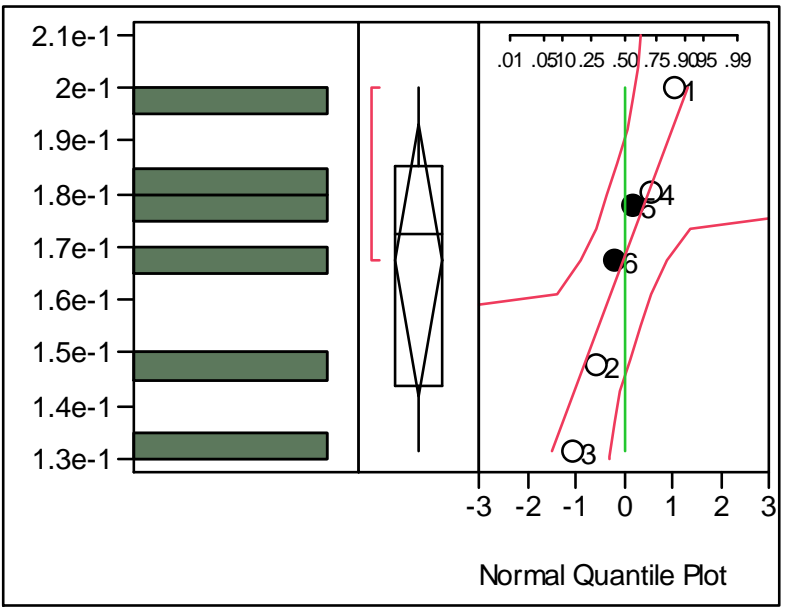

\section{Quantiles}

$\begin{array}{lll}100.0 \% & \text { maximum } & 0.19991 \\ 75.0 \% & \text { quartile } & 0.18529 \\ 50.0 \% & \text { median } & 0.17259 \\ 25.0 \% & \text { quartile } & 0.14363 \\ 0.0 \% & \text { minimum } & 0.13130\end{array}$

\section{Moments}

upper 95\% Mean

\section{Mean}

Std Dev

Std Err Mean

lower 95\% Mean

$\mathrm{N}$

0.1674244

0.0245827

0.0100358

0.1932224

0.1416265

Upper 95\% Confidence Limit

Parameter Estimate

Mean

Std Dev
0.167424

0.024583
Upper Cl

0.187647

0.05136
Tank 19F, NITRATE, Wt\% Dried Solids

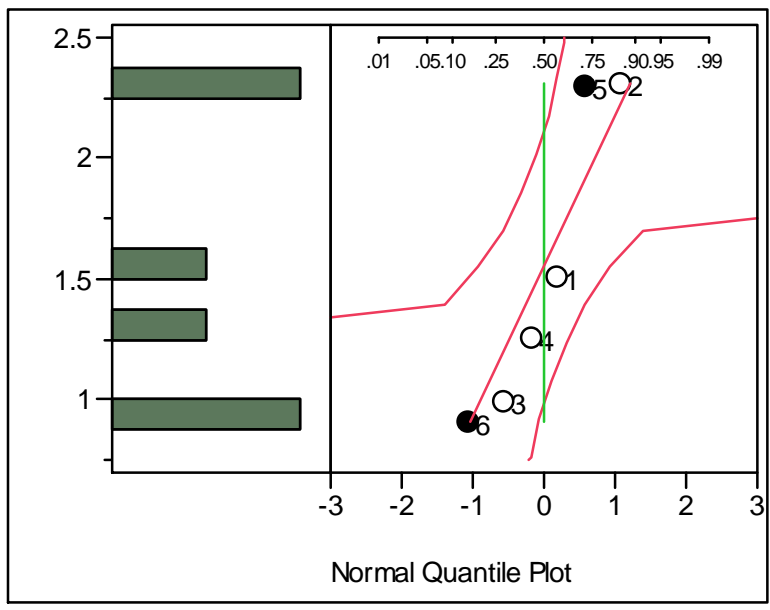

Quantiles

$\begin{array}{lll}100.0 \% & \text { maximum } & 2.3100 \\ 75.0 \% & \text { quartile } & 2.3025 \\ 50.0 \% & \text { median } & 1.3850 \\ 25.0 \% & \text { quartile } & 0.9695 \\ 0.0 \% & \text { minimum } & 0.9080\end{array}$

\section{Moments}

$\begin{array}{lr}\text { Mean } & 1.5463333 \\ \text { Std Dev } & 0.6247373 \\ \text { Std Err Mean } & 0.2550479 \\ \text { upper 95\% Mean } & 2.2019549 \\ \text { lower 95\% Mean } & 0.8907118 \\ \text { N } & 6\end{array}$

Upper 95\% Confidence Limit

Parameter Estimate Upper Cl

$\begin{array}{lll}\text { Mean } & 1.546333 & 2.060267\end{array}$

$\begin{array}{lll}\text { Std Dev } & 0.624737 & 1.305237\end{array}$ 
Tank 19F, NITRITE, Wt\% Dried Solids

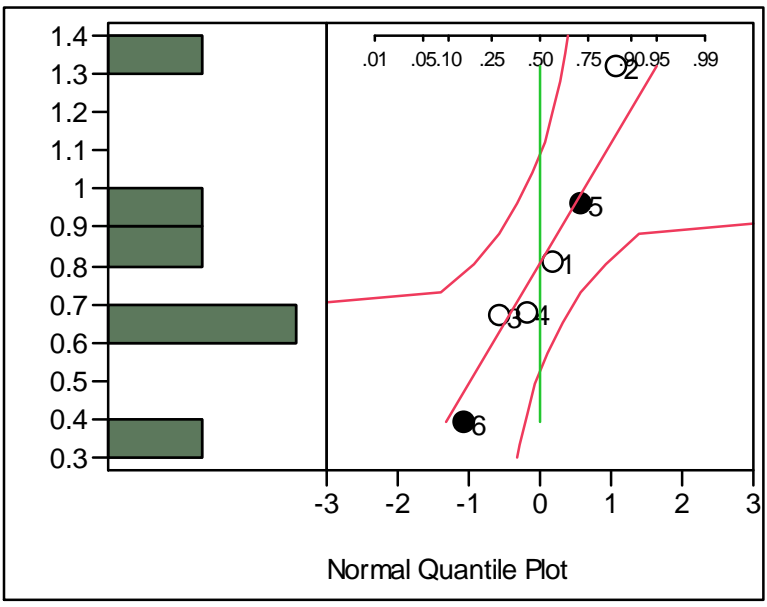

\section{Quantiles}

$\begin{array}{lll}100.0 \% & \text { maximum } & 1.3200 \\ 75.0 \% & \text { quartile } & 1.0523 \\ 50.0 \% & \text { median } & 0.7465 \\ 25.0 \% & \text { quartile } & 0.6028 \\ 0.0 \% & \text { minimum } & 0.3920\end{array}$

\section{Moments}

$\begin{array}{lr}\text { Mean } & 0.8068333 \\ \text { Std Dev } & 0.3141932 \\ \text { Std Err Mean } & 0.1282688 \\ \text { upper 95\% Mean } & 1.1365589 \\ \text { lower 95\% Mean } & 0.4771078 \\ \mathrm{~N} & 6\end{array}$

Upper 95\% Confidence Limit Parameter

Mean

Std Dev

Estimate

0.806833

0.314193

Upper Cl

1.065301

0.65643
Tank 19F, Np-237, uCi/g, Dried Solids

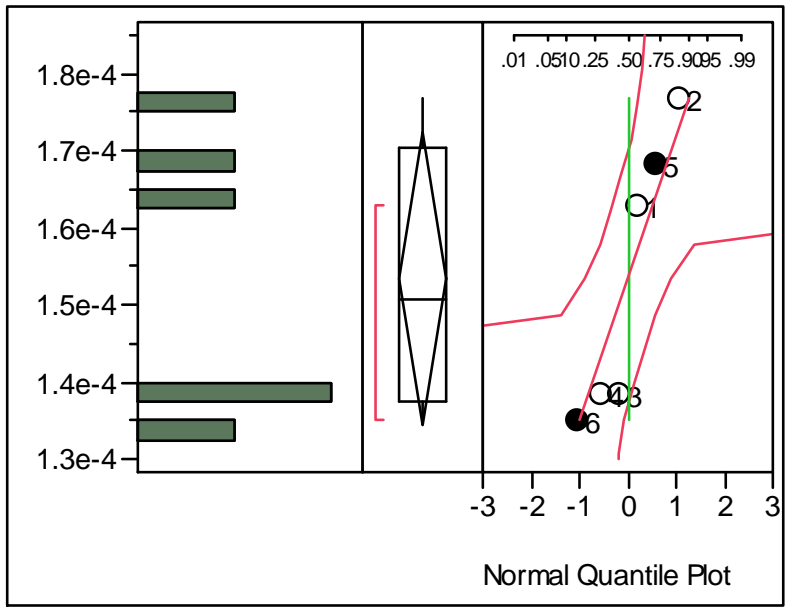

\section{Quantiles}

$\begin{array}{lll}100.0 \% & \text { maximum } & 0.00018 \\ 75.0 \% & \text { quartile } & 0.00017 \\ 50.0 \% & \text { median } & 0.00015 \\ 25.0 \% & \text { quartile } & 0.00014 \\ 0.0 \% & \text { minimum } & 0.00013\end{array}$

\section{Moments}

$\begin{array}{lr}\text { Mean } & 0.0001533 \\ \text { Std Dev } & 1.8136 \mathrm{e}-5 \\ \text { Std Err Mean } & 7.4042 \mathrm{e}-6 \\ \text { upper 95\% Mean } & 0.0001723 \\ \text { lower 95\% Mean } & 0.0001343 \\ \mathrm{~N} & 6\end{array}$

Upper 95\% Confidence Limit

Parameter Estimate

Mean 0.000153

Std Dev $\quad 1.814 \mathrm{e}-5$

Upper Cl

0.000168

$3.789 \mathrm{e}-5$ 
Tank 19F, Pd-107, uCi/g, Dry Solids

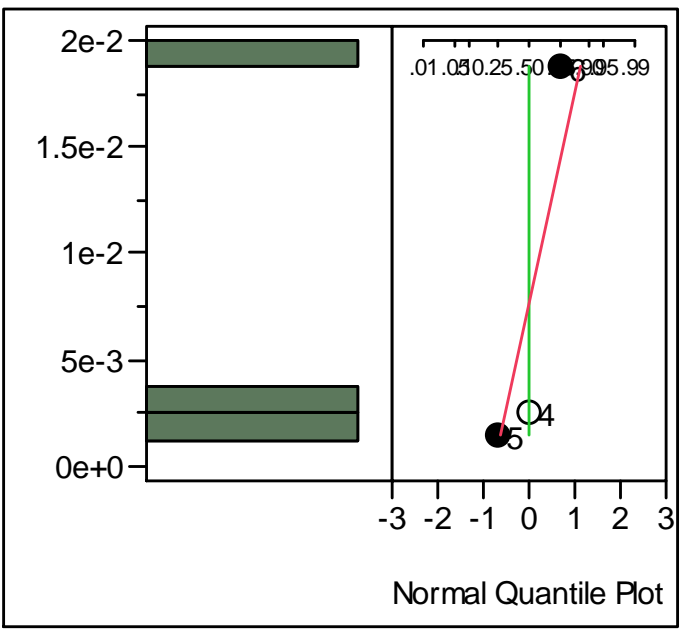

\section{Quantiles}

$\begin{array}{lll}100.0 \% & \text { maximum } & 0.01878 \\ 75.0 \% & \text { quartile } & 0.01878 \\ 50.0 \% & \text { median } & 0.00256 \\ 25.0 \% & \text { quartile } & 0.00142 \\ 0.0 \% & \text { minimum } & 0.00142\end{array}$

\section{Moments}

$\begin{array}{lr}\text { Mean } & 0.0075853 \\ \text { Std Dev } & 0.0097104 \\ \text { Std Err Mean } & 0.0056063 \\ \mathrm{~N} & 3\end{array}$

Upper 95\% Confidence Limit

Parameter

Estimate 0.007585

95\% Upper Cl

Mean
Tank 19F, Pu-238, uCi/g, Dried Solids

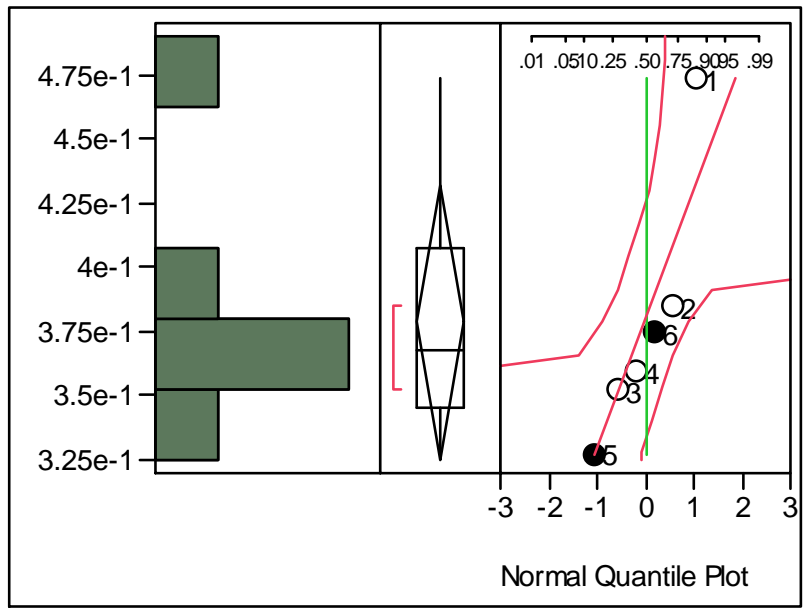

\section{Quantiles}

$\begin{array}{lll}100.0 \% & \text { maximum } & 0.47408 \\ 75.0 \% & \text { quartile } & 0.40737 \\ 50.0 \% & \text { median } & 0.36751 \\ 25.0 \% & \text { quartile } & 0.34584 \\ 0.0 \% & \text { minimum } & 0.32656\end{array}$

\section{Moments}

$\begin{array}{lr}\text { Mean } & 0.3788425 \\ \text { Std Dev } & 0.0508231 \\ \text { Std Err Mean } & 0.0207484 \\ \text { upper 95\% Mean } & 0.4321781 \\ \text { lower 95\% Mean } & 0.325507 \\ \text { N } & 6\end{array}$

Upper 95\% Confidence Limit

$\begin{array}{lll}\text { Parameter } & \text { Estimate } & \text { Upper Cl } \\ \text { Mean } & 0.378843 & 0.420652 \\ \text { Std Dev } & 0.050823 & 0.106182\end{array}$


Tank 19F, Pu-239, uCi/g, Dried Solids

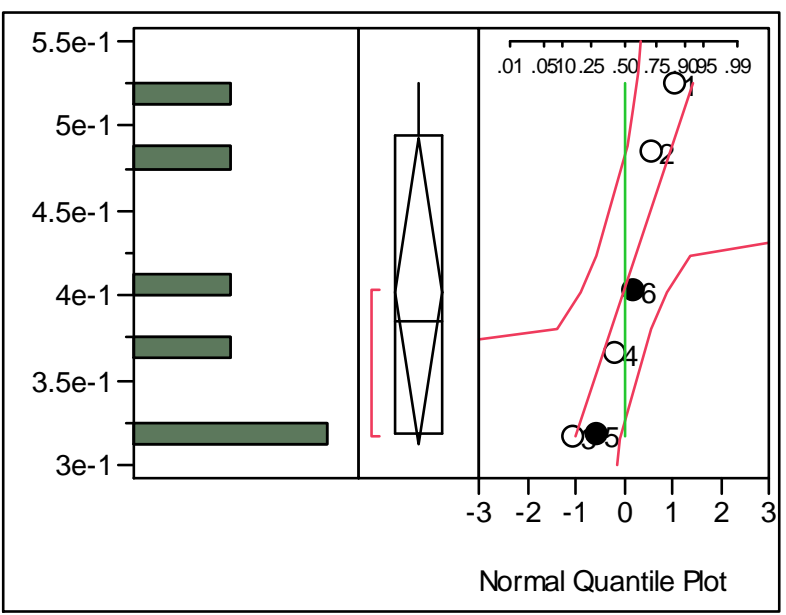

\section{Quantiles}

$\begin{array}{lll}100.0 \% & \text { maximum } & 0.52476 \\ 75.0 \% & \text { quartile } & 0.49471 \\ 50.0 \% & \text { median } & 0.38480 \\ 25.0 \% & \text { quartile } & 0.31797 \\ 0.0 \% & \text { minimum } & 0.31748\end{array}$

\section{Moments}

\section{Mean}

Std Dev

Std Err Mean

upper 95\% Mean

lower 95\% Mean

N

Upper 95\% Confidence Limit

Parameter

Mean

Std Dev
Estimate

0.402443

0.086435
0.4024426

0.0864348

0.0352868

0.4931503

0.3117349

\section{Tank 19F, Pu-240, uCi/g, Dried Solids}

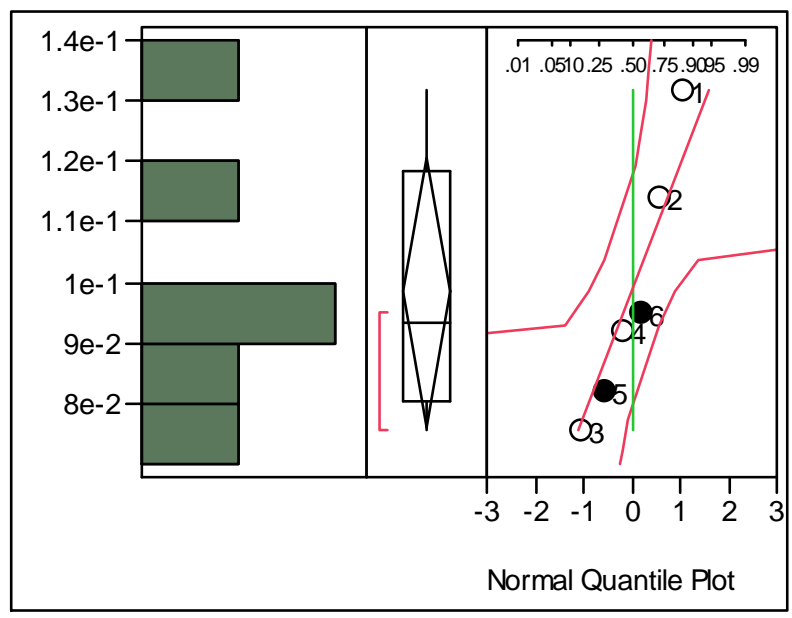

\section{Quantiles}

$\begin{array}{lll}100.0 \% & \text { maximum } & 0.13198 \\ 75.0 \% & \text { quartile } & 0.11851 \\ 50.0 \% & \text { median } & 0.09344 \\ 25.0 \% & \text { quartile } & 0.08030 \\ 0.0 \% & \text { minimum } & 0.07544\end{array}$

\section{Moments}

$\begin{array}{lr}\text { Mean } & 0.0983748 \\ \text { Std Dev } & 0.0210899 \\ \text { Std Err Mean } & 0.0086099 \\ \text { upper 95\% Mean } & 0.1205072 \\ \text { lower 95\% Mean } & 0.0762423 \\ \text { N } & 6\end{array}$

Upper 95\% Confidence Limit Parameter Estimate Mean $\quad 0.098375$

Std Dev $\quad 0.02109$
Upper Cl

0.115724

0.044062 
Tank 19F, Pu-241, uCi/g, Dried Solids

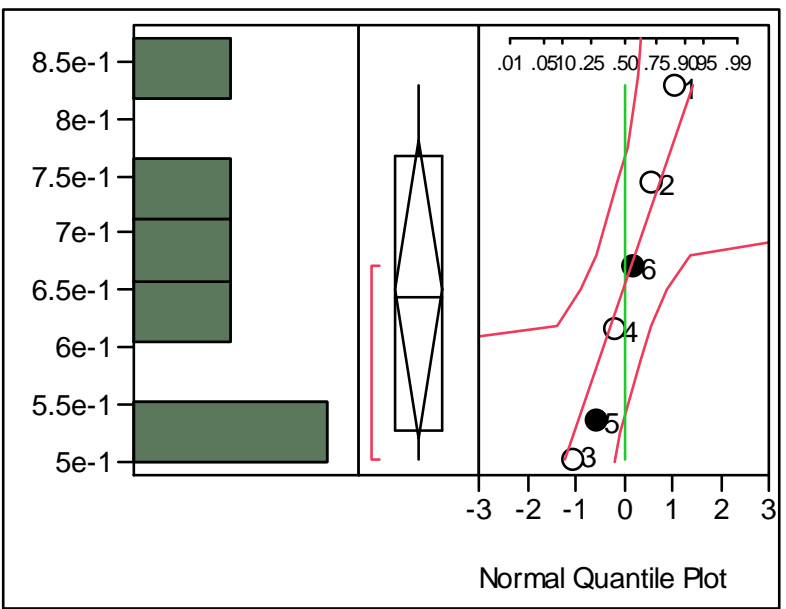

\section{Quantiles}

$\begin{array}{lll}100.0 \% & \text { maximum } & 0.82920 \\ 75.0 \% & \text { quartile } & 0.76613 \\ 50.0 \% & \text { median } & 0.64405 \\ 25.0 \% & \text { quartile } & 0.52848 \\ 0.0 \% & \text { minimum } & 0.50115\end{array}$

\section{Moments}

\section{Mean}

Std Dev

Std Err Mean

upper 95\% Mean

lower 95\% Mean

N

Upper 95\% Confidence Limit

Parameter

Mean

Std Dev

\section{Estimate}

0.650191

0.124485
0.6501908

0.1244847

0.0508206

0.7808294

0.5195522
82920

.52848

6

\section{Tank 19F, Ra-226, uCi/g, Dried Solids}

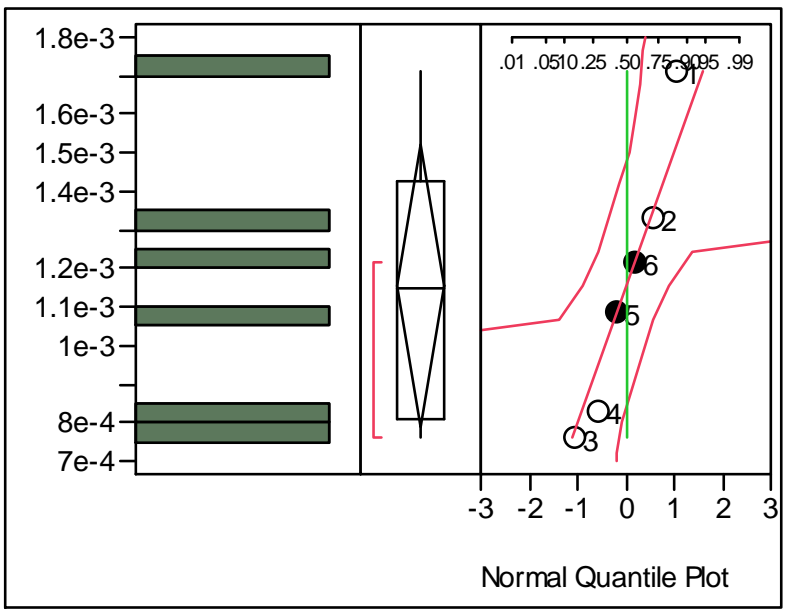

\section{Quantiles}

$\begin{array}{lll}100.0 \% & \text { maximum } & 0.00171 \\ 75.0 \% & \text { quartile } & 0.00142 \\ 50.0 \% & \text { median } & 0.00115 \\ 25.0 \% & \text { quartile } & 0.00081 \\ 0.0 \% & \text { minimum } & 0.00076\end{array}$

\section{Moments}

$\begin{array}{lr}\text { Mean } & 0.0011545 \\ \text { Std Dev } & 0.0003499 \\ \text { Std Err Mean } & 0.0001428 \\ \text { upper 95\% Mean } & 0.0015216 \\ \text { lower 95\% Mean } & 0.0007873 \\ \mathrm{~N} & 6\end{array}$

Upper 95\% Confidence Limit

Mean $\quad 0.001154$

Std Dev $\quad 0.00035$

Upper Cl

0.001442

0.260081

0.000731 
Tank 19F, Sb-126, uCi/g, Dried Solids

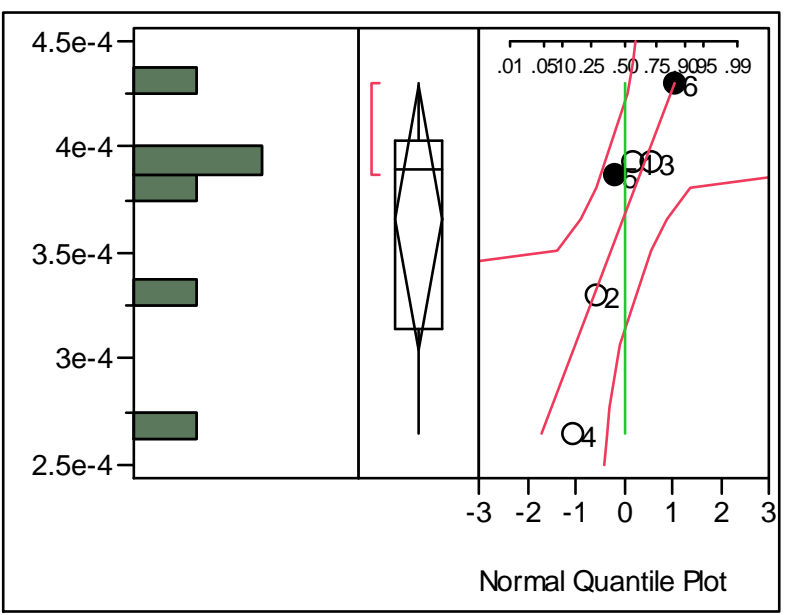

\section{Quantiles}

$\begin{array}{lll}100.0 \% & \text { maximum } & 0.00043 \\ 75.0 \% & \text { quartile } & 0.00040 \\ 50.0 \% & \text { median } & 0.00039 \\ 25.0 \% & \text { quartile } & 0.00031 \\ 0.0 \% & \text { minimum } & 0.00026\end{array}$

\section{Moments}

\section{Mean}

Std Dev

Std Err Mean

upper 95\% Mean

lower 95\% Mean

$\mathrm{N}$

Upper 95\% Confidence Limit

Parameter

Mean

Std Dev

\section{Estimate}

0.000366

$5.944 \mathrm{e}-5$

$$
\begin{array}{r}
0.0003664 \\
5.944 \mathrm{e}-5 \\
2.4266 \mathrm{e}-5 \\
0.0004288 \\
0.0003041
\end{array}
$$

Tank 19F, Sb-126m, uCi/g, Dried Solids

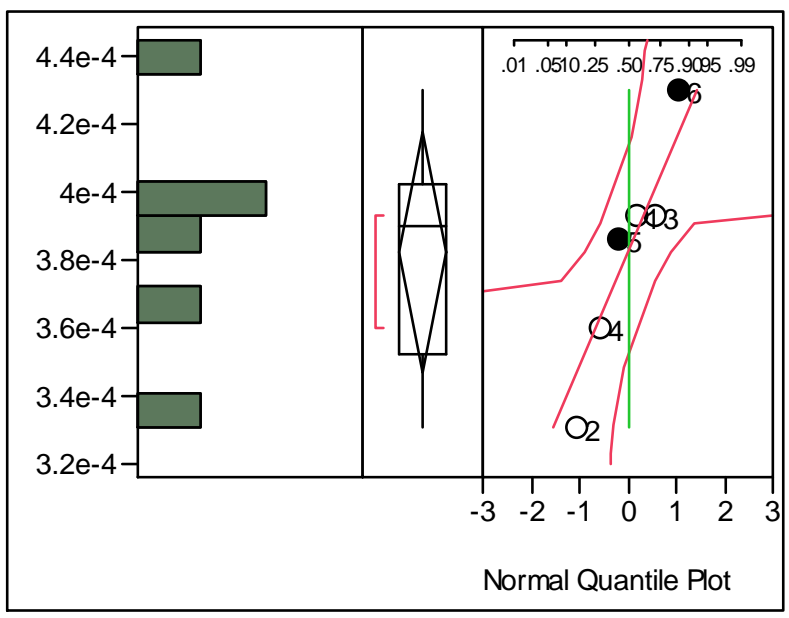

\section{Quantiles}

$\begin{array}{lll}100.0 \% & \text { maximum } & 0.00043 \\ 75.0 \% & \text { quartile } & 0.00040 \\ 50.0 \% & \text { median } & 0.00039 \\ 25.0 \% & \text { quartile } & 0.00035 \\ 0.0 \% & \text { minimum } & 0.00033\end{array}$

\section{Moments}

$\begin{array}{lr}\text { Mean } & 0.0003824 \\ \text { Std Dev } & 3.3912 \mathrm{e}-5 \\ \text { Std Err Mean } & 1.3845 \mathrm{e}-5 \\ \text { upper 95\% Mean } & 0.000418 \\ \text { lower 95\% Mean } & 0.0003468 \\ \mathrm{~N} & 6\end{array}$

Upper 95\% Confidence Limit Parameter Estimate Mean 0.000382
Std Dev 0.000034
0.00041

$7.085 \mathrm{e}-5$ 
Tank 19F, Sm-151, uCi/g, Dried Solids

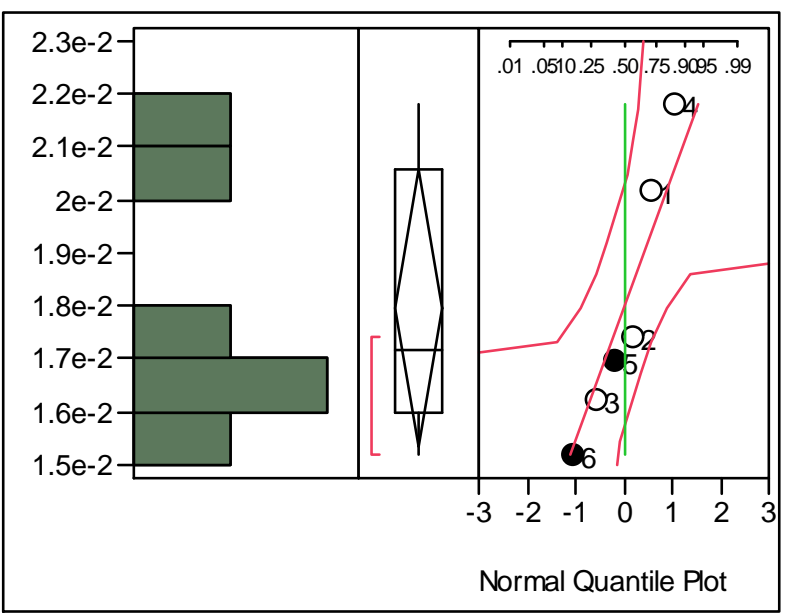

\section{Quantiles}

$\begin{array}{lll}100.0 \% & \text { maximum } & 0.02180 \\ 75.0 \% & \text { quartile } & 0.02057 \\ 50.0 \% & \text { median } & 0.01720 \\ 25.0 \% & \text { quartile } & 0.01599 \\ 0.0 \% & \text { minimum } & 0.01521\end{array}$

\section{Moments}

\section{Mean}

Std Dev

Std Err Mean

upper $95 \%$ Mean

lower $95 \%$ Mean

$\mathrm{N}$

Upper 95\% Confidence Limit

Parameter

Mean

Std Dev

\section{Estimate}

0.017969

0.002503
0.0179695

0.0025034

0.001022

0.0205967

0.0153423
Tank 19F, Sn-126, uCi/g, Dried Solids

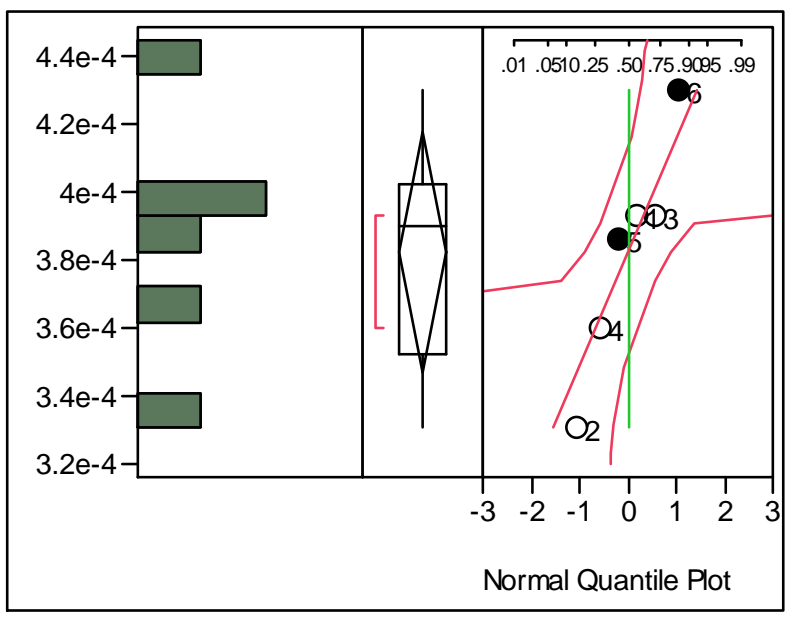

\section{Quantiles}

$\begin{array}{lll}100.0 \% & \text { maximum } & 0.00043 \\ 75.0 \% & \text { quartile } & 0.00040 \\ 50.0 \% & \text { median } & 0.00039 \\ 25.0 \% & \text { quartile } & 0.00035 \\ 0.0 \% & \text { minimum } & 0.00033\end{array}$

\section{Moments}

$\begin{array}{lr}\text { Mean } & 0.0003824 \\ \text { Std Dev } & 3.3912 \mathrm{e}-5 \\ \text { Std Err Mean } & 1.3845 \mathrm{e}-5 \\ \text { upper 95\% Mean } & 0.000418 \\ \text { lower 95\% Mean } & 0.0003468 \\ \mathrm{~N} & 6\end{array}$

Upper 95\% Confidence Limit Parameter Estimate Mean 0.000382

Std Dev $\quad 0.000034$
Upper Cl

0.00041

$7.085 \mathrm{e}-5$ 
Tank 19F, Sr-90, uCi/g, Dried Solids

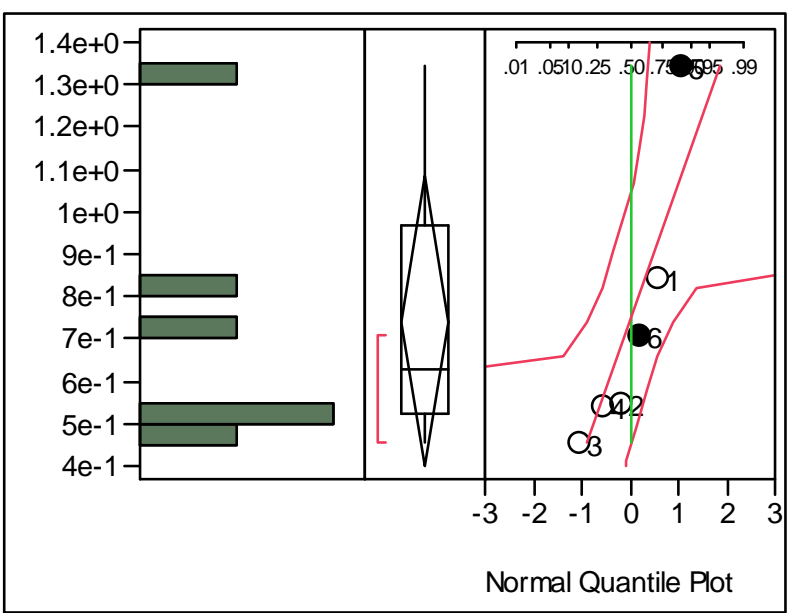

\section{Quantiles}

$\begin{array}{lll}100.0 \% & \text { maximum } & 1.3434 \\ 75.0 \% & \text { quartile } & 0.9694 \\ 50.0 \% & \text { median } & 0.6271 \\ 25.0 \% & \text { quartile } & 0.5209 \\ 0.0 \% & \text { minimum } & 0.4567\end{array}$

\section{Moments}

$\begin{array}{lr}\text { Mean } & 0.7402076 \\ \text { Std Dev } & 0.3262928 \\ \text { Std Err Mean } & 0.1332085 \\ \text { upper 95\% Mean } & 1.0826309 \\ \text { lower 95\% Mean } & 0.3977843 \\ \mathrm{~N} & 6\end{array}$

Upper 95\% Confidence Limit

Parameter Estimate

Mean

Std Dev
Tank 19F, Tc-99, uCi/g, Dried Solids

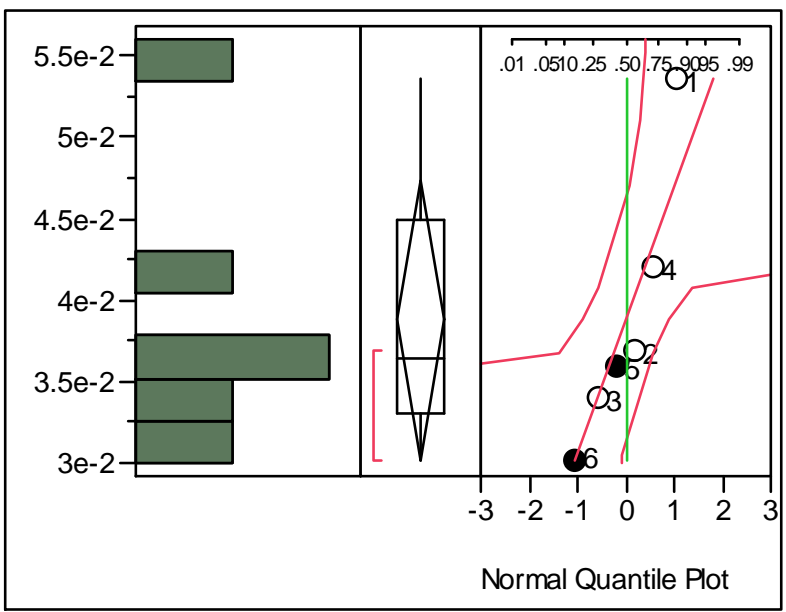

\section{Quantiles}

$\begin{array}{lll}100.0 \% & \text { maximum } & 0.05360 \\ 75.0 \% & \text { quartile } & 0.04487 \\ 50.0 \% & \text { median } & 0.03637 \\ 25.0 \% & \text { quartile } & 0.03310 \\ 0.0 \% & \text { minimum } & 0.03014\end{array}$

\section{Moments}

$\begin{array}{lr}\text { Mean } & 0.038753 \\ \text { Std Dev } & 0.0082289 \\ \text { Std Err Mean } & 0.0033594 \\ \text { upper 95\% Mean } & 0.0473887 \\ \text { lower 95\% Mean } & 0.0301173 \\ \text { N } & 6\end{array}$

Upper 95\% Confidence Limit

Parameter Estimate

Mean 0.038753

Upper Cl

0.045522

Std Dev $\quad 0.008229$
0.017192 
Tank 19F, Th-229, uCi/g Dry Solids

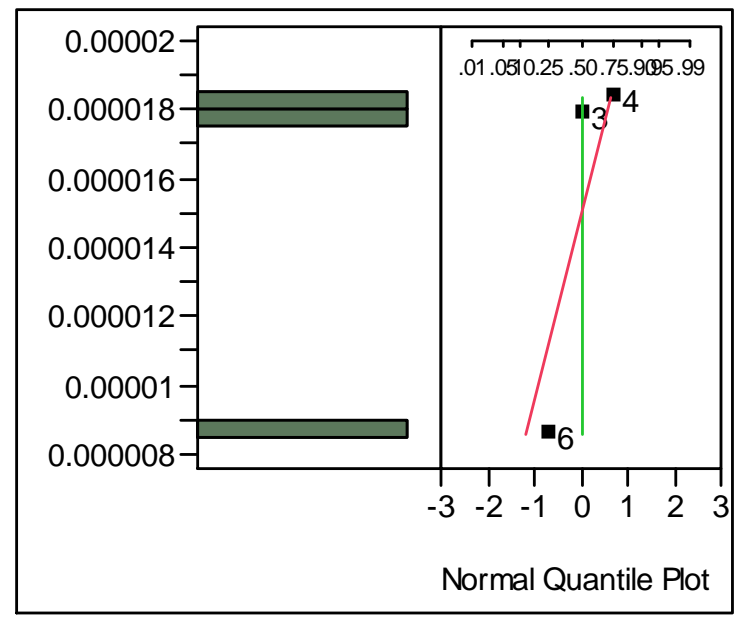

\section{Moments}

$\begin{array}{lr}\text { Mean } & 1.4928 \mathrm{e}-5 \\ \text { Std Dev } & 5.519 \mathrm{e}-6 \\ \mathrm{~N} & 3\end{array}$

Upper 95\% Confidence Limit

Parameter

Mean

Estimate 0.000015
Tank 19F, Th-230, uCi/g Dry Solids

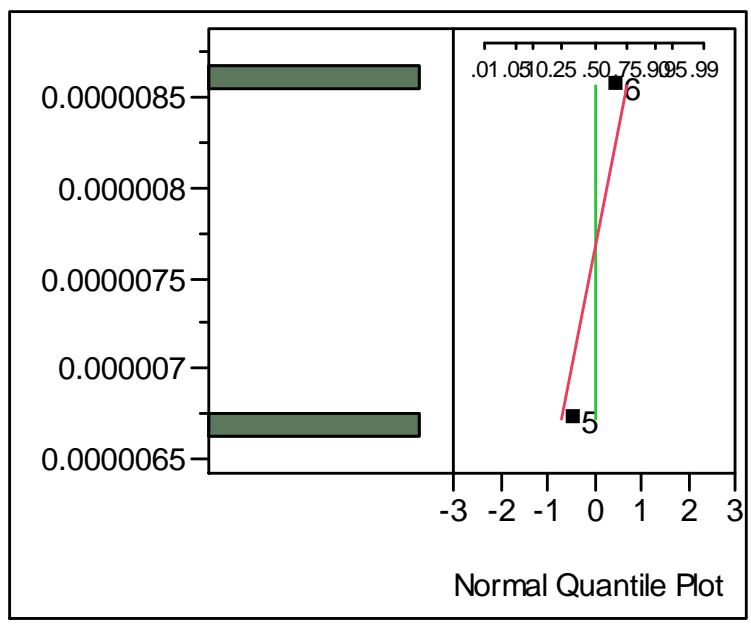

\section{Moments}

$\begin{array}{lr}\text { Mean } & 7.6403 e-6 \\ \text { Std Dev } & 0.0000013 \\ \text { N } & 2\end{array}$

Upper 95\% Confidence Limit Parameter Estimate $95 \%$ Upper Cl Mean $\quad 7.64 \mathrm{e}-6 \quad 1.345 \mathrm{e}-5$ 
Tank 19F, Ti, Wt\%, Dried Solids

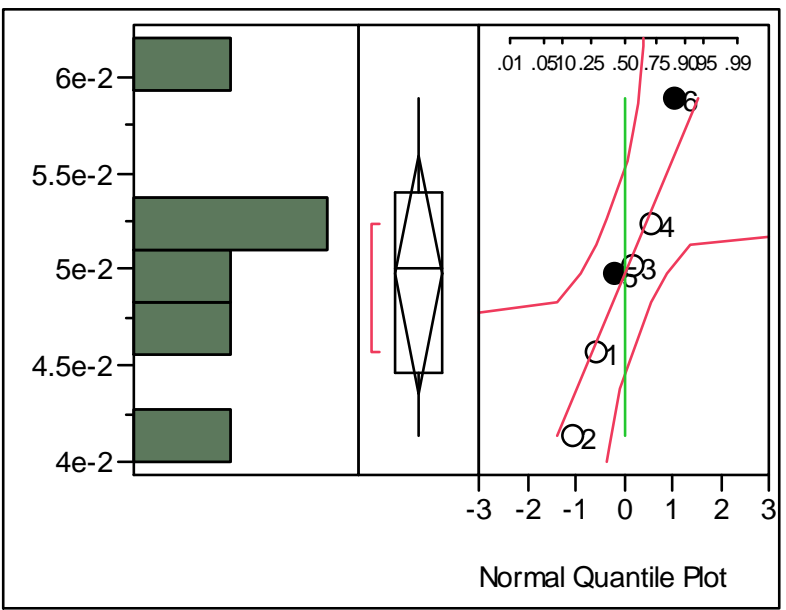

\section{Quantiles}

$\begin{array}{lll}100.0 \% & \text { maximum } & 0.05889 \\ 75.0 \% & \text { quartile } & 0.05396 \\ 50.0 \% & \text { median } & 0.05001 \\ 25.0 \% & \text { quartile } & 0.04463 \\ 0.0 \% & \text { minimum } & 0.04138\end{array}$

\section{Moments}

Mean

Std Dev

Std Err Mean upper 95\% Mean lower 95\% Mean $\mathrm{N}$

0.0497201 0.0059425

0.002426

0.0559563

0.0434839

Upper 95\% Confidence Limit

Parameter

Mean

Std Dev
Estimate

0.04972

0.005942
Upper Cl

0.054609

0.012415
Tank 19F, U-232, uCi/g, Dried Solids

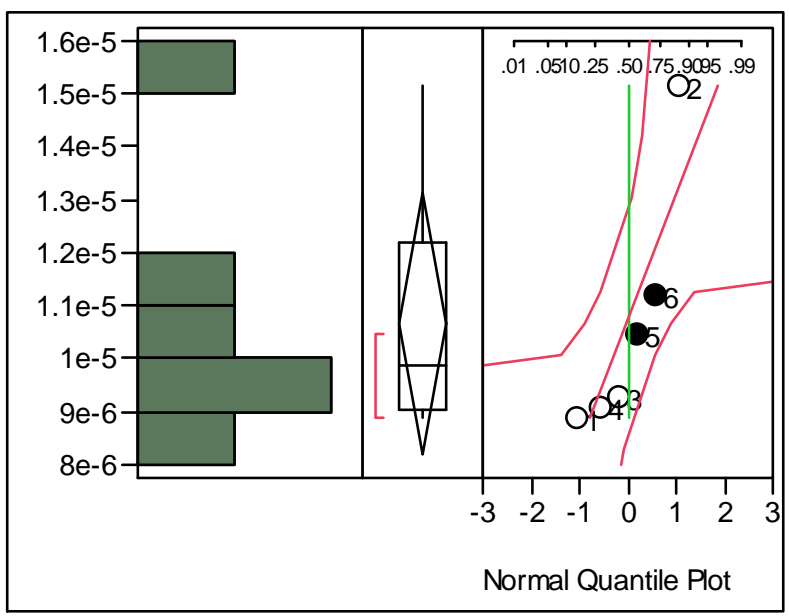

\section{Quantiles}

$\begin{array}{llr}100.0 \% & \text { maximum } & 1.51 \mathrm{e}-5 \\ 75.0 \% & \text { quartile } & 1.22 \mathrm{e}-5 \\ 50.0 \% & \text { median } & 0.00001 \\ 25.0 \% & \text { quartile } & 0.00001 \\ 0.0 \% & \text { minimum } & 8.87 \mathrm{e}-6\end{array}$

\section{Moments}

Mean

1.0669e-5

Std Dev

2.3702e-6

Std Err Mean

9.6761e-7

upper 95\% Mean

$1.3156 \mathrm{e}-5$

lower 95\% Mean

8.1814e-6

Upper 95\% Confidence Limit

Parameter

Estimate

Mean

1.067e-5

Upper Cl

Std Dev

$2.37 \mathrm{e}-6$

1.262e-5

4.952e-6 
Tank 19F, U-233, uCi/g, Dried Solids

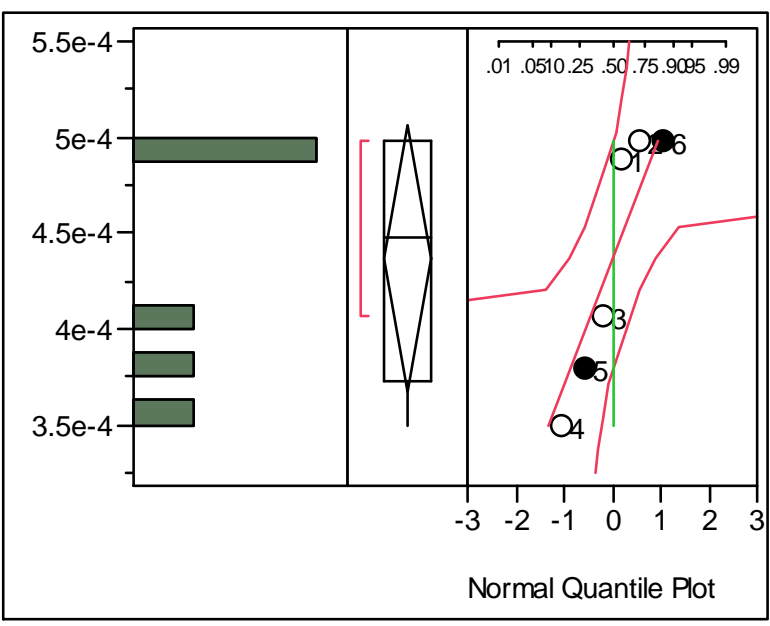

\section{Quantiles}

$\begin{array}{lll}100.0 \% & \text { maximum } & 0.00050 \\ 75.0 \% & \text { quartile } & 0.00050 \\ 50.0 \% & \text { median } & 0.00045 \\ 25.0 \% & \text { quartile } & 0.00037 \\ 0.0 \% & \text { minimum } & 0.00035\end{array}$

\section{Moments}

Mean

Std Dev

Std Err Mean

upper $95 \%$ Mean

lower 95\% Mean

$\mathrm{N}$

\section{Upper 95\% Confidence Limit}

Parameter

Mean

Std Dev

Estimate

0.000437

0.000066

Upper Cl

0.000491

0.000138
Tank 19F, U-234, uCi/g, Dried Solids

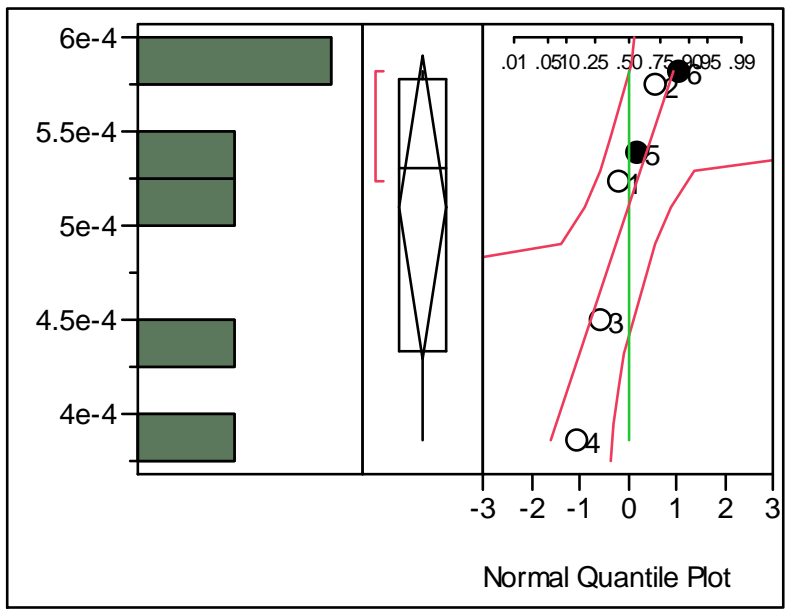

\section{Quantiles}

$\begin{array}{lll}100.0 \% & \text { maximum } & 0.00058 \\ 75.0 \% & \text { quartile } & 0.00058 \\ 50.0 \% & \text { median } & 0.00053 \\ 25.0 \% & \text { quartile } & 0.00043 \\ 0.0 \% & \text { minimum } & 0.00039\end{array}$

\section{Moments}

Mean

0.0005093

Std Dev

0.0000768

Std Err Mean

$3.1352 \mathrm{e}-5$

upper $95 \%$ Mean

0.0005899

lower $95 \%$ Mean

0.0004287
6

$\mathrm{N}$

Upper 95\% Confidence Limit

Parameter Estimate

Mean

0.000509

Upper Cl

Std Dev

$7.68 \mathrm{e}-5$
0.000572

0.00016 
Tank 19F, U-235, uCi/g, Dried Solids

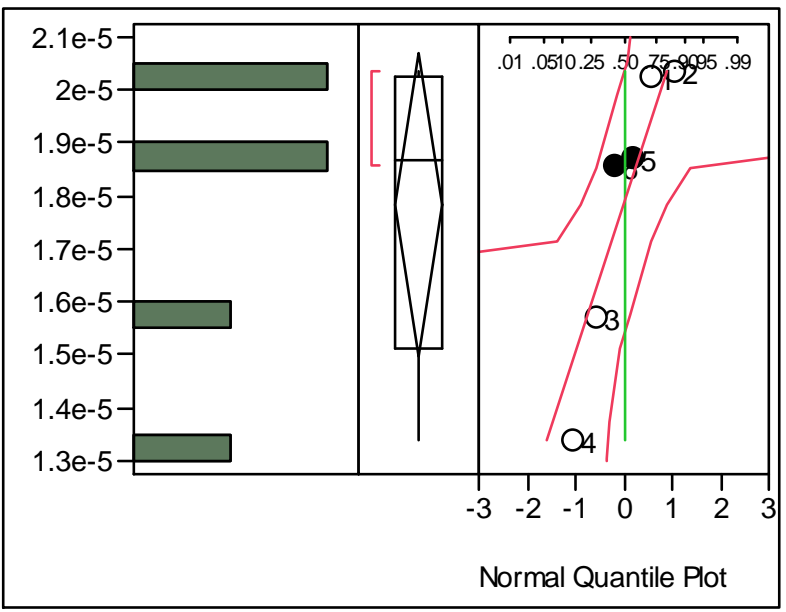

\section{Quantiles}

$\begin{array}{lll}100.0 \% & \text { maximum } & 0.00002 \\ 75.0 \% & \text { quartile } & 0.00002 \\ 50.0 \% & \text { median } & 1.87 \mathrm{e}-5 \\ 25.0 \% & \text { quartile } & 1.51 \mathrm{e}-5 \\ 0.0 \% & \text { minimum } & 1.34 \mathrm{e}-5\end{array}$

\section{Moments}

$\begin{array}{lr}\text { Mean } & 1.7837 \mathrm{e}-5 \\ \text { Std Dev } & 2.7354 \mathrm{e}-6 \\ \text { Std Err Mean } & 1.1167 \mathrm{e}-6 \\ \text { upper 95\% Mean } & 0.0000207 \\ \text { lower 95\% Mean } & 1.4967 \mathrm{e}-5 \\ \mathrm{~N} & 6\end{array}$

Upper 95\% Confidence Limit Parameter Estimate Mean $1.784 \mathrm{e}-5$

Std Dev
Upper Cl

0.00002

$5.715 \mathrm{e}-6$
Tank 19F, U-236, uCi/g, Dried Solids

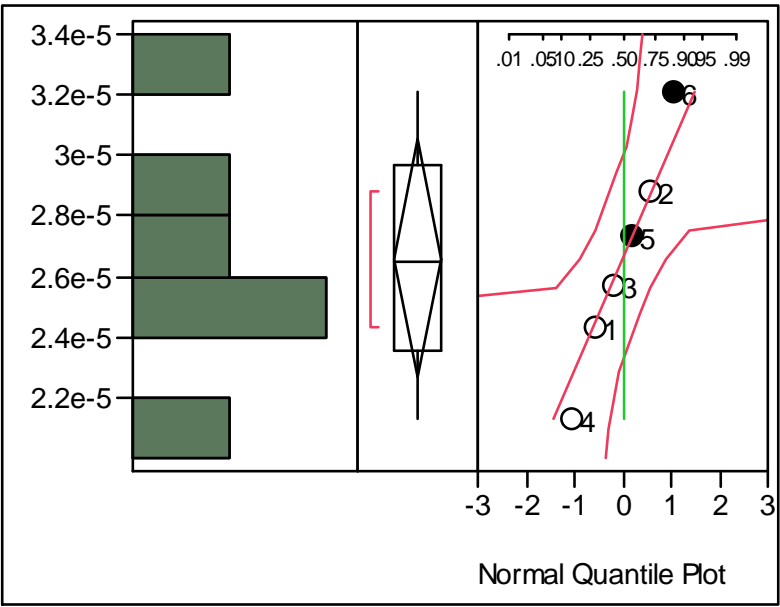

\section{Quantiles}

$\begin{array}{llr}100.0 \% & \text { maximum } & 3.21 \mathrm{e}-5 \\ 75.0 \% & \text { quartile } & 0.00003 \\ 50.0 \% & \text { median } & 2.65 \mathrm{e}-5 \\ 25.0 \% & \text { quartile } & 2.35 \mathrm{e}-5 \\ 0.0 \% & \text { minimum } & 2.13 \mathrm{e}-5\end{array}$

\section{Moments}

$\begin{array}{lr}\text { Mean } & 2.6584 \mathrm{e}-5 \\ \text { Std Dev } & 3.7427 \mathrm{e}-6 \\ \text { Std Err Mean } & 1.528 \mathrm{e}-6 \\ \text { upper 95\% Mean } & 3.0512 \mathrm{e}-5 \\ \text { lower 95\% Mean } & 2.2657 \mathrm{e}-5 \\ \mathrm{~N} & 6\end{array}$

Upper 95\% Confidence Limit Parameter Estimate Mean 2.658e-5

Std Dev 3.743e-6 
Tank 19F, U-238, uCi/g, Dried Solids

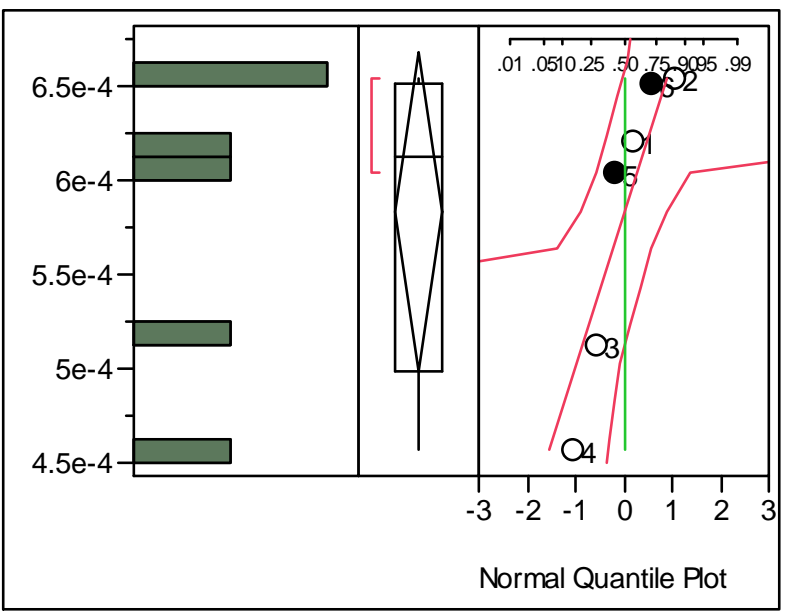

\section{Quantiles}

$\begin{array}{lll}100.0 \% & \text { maximum } & 0.00065 \\ 75.0 \% & \text { quartile } & 0.00065 \\ 50.0 \% & \text { median } & 0.00061 \\ 25.0 \% & \text { quartile } & 0.00050 \\ 0.0 \% & \text { minimum } & 0.00046\end{array}$

\section{Moments}

$\begin{array}{lr}\text { Mean } & 0.0005836 \\ \text { Std Dev } & 8.0534 \mathrm{e}-5 \\ \text { Std Err Mean } & 3.2878 \mathrm{e}-5 \\ \text { upper 95\% Mean } & 0.0006682 \\ \text { lower 95\% Mean } & 0.0004991 \\ \mathrm{~N} & 6\end{array}$

Upper 95\% Confidence Limit Parameter

Mean

Std Dev

Estimate

0.000584

$8.053 e-5$

Upper Cl

0.00065

0.000168
Tank 19F, Y-90, uCi/g, Dried Solids

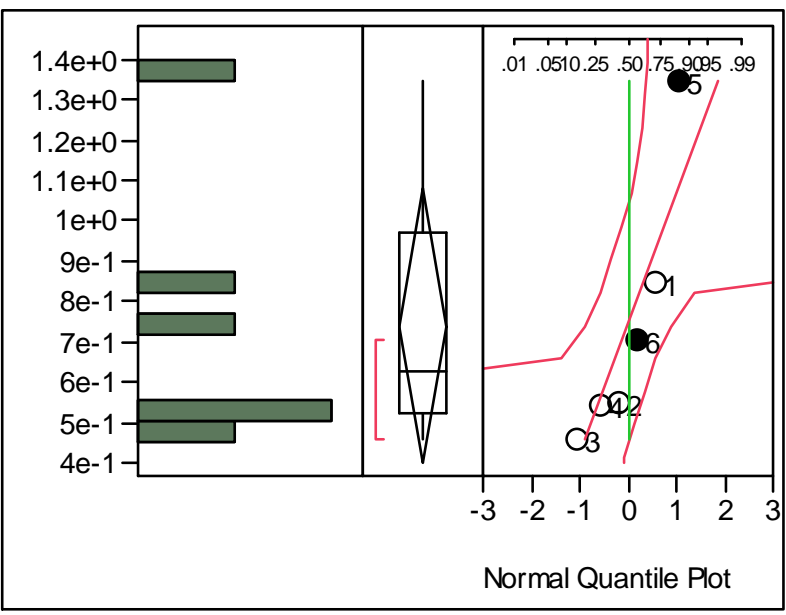

\section{Quantiles}

$\begin{array}{lll}100.0 \% & \text { maximum } & 1.3434 \\ 75.0 \% & \text { quartile } & 0.9694 \\ 50.0 \% & \text { median } & 0.6271 \\ 25.0 \% & \text { quartile } & 0.5209 \\ 0.0 \% & \text { minimum } & 0.4567\end{array}$

\section{Moments}

$\begin{array}{lr}\text { Mean } & 0.7402076 \\ \text { Std Dev } & 0.3262928 \\ \text { Std Err Mean } & 0.1332085 \\ \text { upper 95\% Mean } & 1.0826309 \\ \text { lower 95\% Mean } & 0.3977843 \\ \text { N } & 6\end{array}$

Upper 95\% Confidence Limit

Parameter Estimate Upper Cl

$\begin{array}{lll}\text { Mean } & 0.740208 & 1.008629\end{array}$

$\begin{array}{lll}\text { Std Dev } & 0.326293 & 0.68171\end{array}$ 
Tank 19F, Zn, Wt\%, Dried Solids

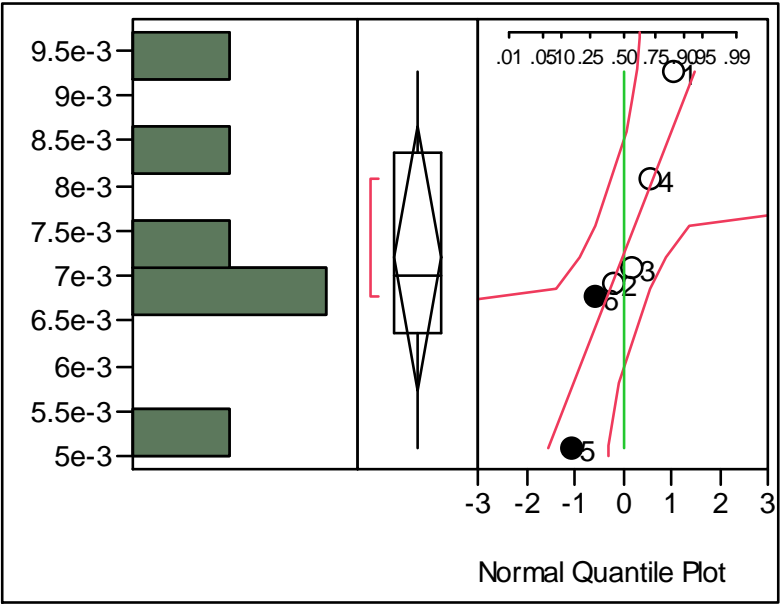

\section{Quantiles}

$\begin{array}{lll}100.0 \% & \text { maximum } & 0.00926 \\ 75.0 \% & \text { quartile } & 0.00837 \\ 50.0 \% & \text { median } & 0.00700 \\ 25.0 \% & \text { quartile } & 0.00635 \\ 0.0 \% & \text { minimum } & 0.00508\end{array}$

\section{Moments}

Mean

0.0071973

Std Dev

Std Err Mean

upper $95 \%$ Mean

lower 95\% Mean

0.0013958

0.0005698

0.0086621

0.0057325

$\mathrm{N}$

Upper 95\% Confidence Limit

Parameter

Mean

Estimate

Std Dev

0.007197

0.001396

Upper Cl

0.008346

0.002916
Tank 19F, Zr-93, uCi/g, Dry Solids

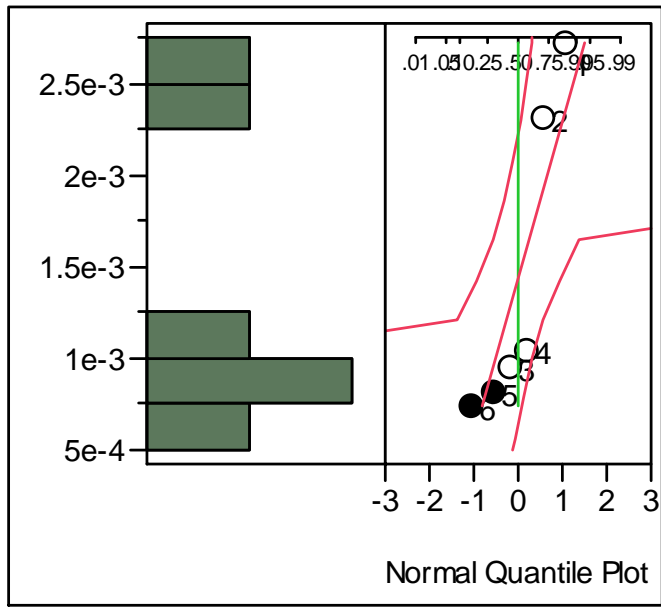

\section{Quantiles}

$\begin{array}{lll}100.0 \% & \text { maximum } & 0.00272 \\ 75.0 \% & \text { quartile } & 0.00242 \\ 50.0 \% & \text { median } & 0.00099 \\ 25.0 \% & \text { quartile } & 0.00079 \\ 0.0 \% & \text { minimum } & 0.00073\end{array}$

Moments

Mean

0.0014286

Std Dev

0.0008622

Std Err Mean

0.000352

Upper 95\% Confidence Limit

Parameter Estimate

Mean

0.001429

95\% Upper Cl 0.002138 
Statistical Analysis of Tank 19F Floor Sample Results

This page intentionally left blank 
Statistical Analysis of Tank 19F Floor Sample Results

\section{Distribution}

W.L. Isom, Jr., 704-26F

R.C. Jolly, 704-70F

B.A. Martin, 705-1C

G.D. Thaxton, IV, 704-70F

F.M. Pennebaker, 773-42A

P.L. Lee, 703-41A

E.P. Shine, 703-41A 